\title{
ESTIMATIVAS DE PARÂMETROS GENÉTICOS E FENOTÍPICOS DE UMA POPULAÇÃO DE SOJA AVALIADA EM QUATRO ANOS
}

\author{
HEIKO ROSSMANN
}

Dissertação apresentada à Escola Superior de Agricultura "Luiz de Queiroz", Universidade de São Paulo, para a obtenção do título de Mestre em Agronomia, Área de Concentração: Genética e Melhoramento de Plantas.

\author{
PIRACICABA \\ Estado de São Paulo - Brasil
}

Novembro de 2001 


\title{
ESTIMATIVAS DE PARÂMETROS GENÉTICOS E FENOTÍPICOS DE UMA POPULAÇÃO DE SOJA AVALIADA EM QUATRO ANOS
}

\section{HEIKO ROSSMANN}

Engenheiro Agrônomo

Orientador: Prof. Dr. ISAIAS OLÍVIO GERALDI

\begin{abstract}
Dissertação apresentada à Escola Superior de Agricultura "Luiz de Queiroz", Universidade de São Paulo, para a obtenção do título de Mestre em Agronomia, Área de Concentração: Genética e Melhoramento de Plantas.
\end{abstract}

\author{
PIRACICABA \\ Estado de São Paulo - Brasil
}

Novembro de 2001 
Dados Internacionais de Catalogação na Publicação (CIP)

DIVISÃO DE BIBLIOTECA E DOCUMENTAÇÃO - Campus “Luiz de Queiroz"/USP

Rossmann, Heiko

Estimativas de parâmetros genéticos e fenotípicos de uma população de soja avaliada em quatro anos / Heiko Rossmann. - - Piracicaba, 2001.

80 p. : il.

Dissertação (mestrado) - - Escola Superior de Agricultura Luiz de Queiroz, 2001. Bibliografia.

1. Correlação genética 2. Ganho genético 3. Herdabilidade 4. Interação genótipoambiente 5. Parâmetro genético 6. Soja I. Título

CDD 633.34

\section{"Permitida a cópia total ou parcial deste documento, desde que citada a fonte - $O$ autor"}




\section{SUMÁRIO}

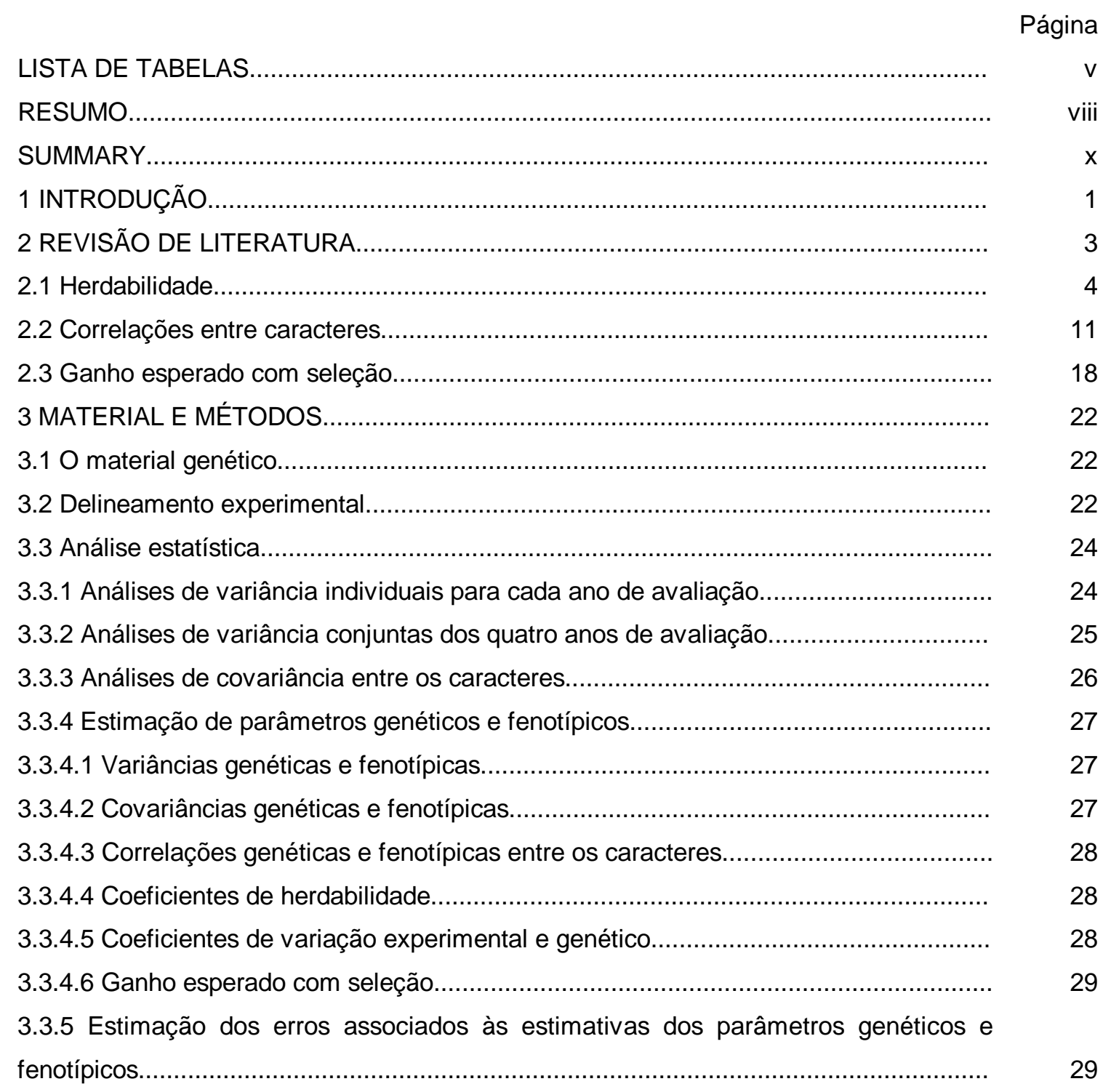


3.3.5.1 Intervalo de confiança associado à estimativa da variância do erro

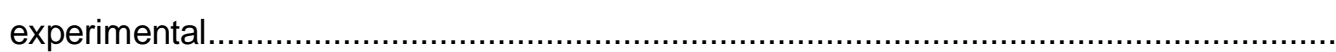

3.3.5.2 Intervalo de confiança associado à estimativa da variância genética de linhagens.

3.3.5.3 Intervalo de confiança associado à estimativa da variância da interação de linhagens com anos......

3.3.5.4 Intervalo de confiança associado à estimativa do coeficiente de herdabilidade na análise conjunta.

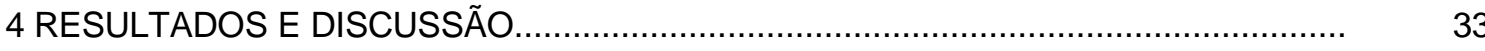

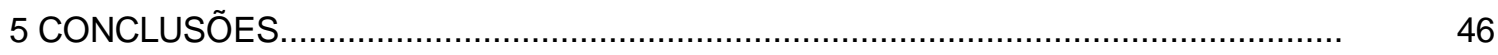

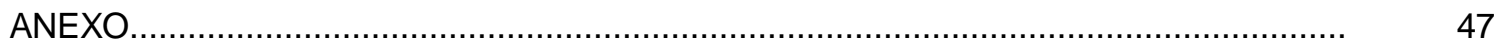

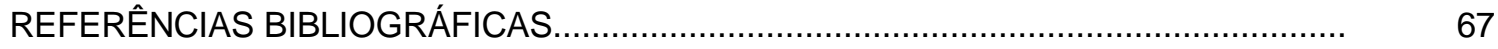

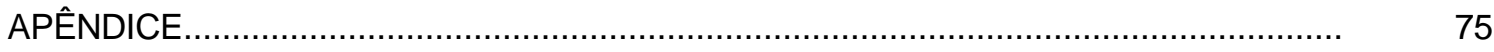




\section{LISTA DE TABELAS}

Página

1 Médias e intervalos de variação das linhagens, para os caracteres altura da planta na maturação ( $\mathrm{AM}$ ), acamamento ( $\mathrm{AC})$, número de dias para maturação (DM) e produção de grãos (PG), em cada um dos anos de experimentação e na média dos quatro anos

2 Médias das testemunhas para os caracteres altura da planta na maturação (AM), acamamento (AC), número de dias para maturação (DM) e produção de grãos (PG), em cada um dos anos de experimentação e na média dos quatro anos.

3 Análises de variância individuais nos anos agrícolas 1995/96, 1996/97, 1998/99 e 1999/00, para os caracteres altura da planta na maturação (AM), acamamento (AC), número de dias para maturação (DM) e produção de grãos (PG).

4 Análises de variância conjunta dos quatro anos para os caracteres altura da planta na maturação (AM), acamamento (AC), número de dias para maturação (DM) e produção de grãos (PG)

5 Estimativas dos coeficientes de variação experimental (CVe\%) em cada um dos anos de experimentação e nas análises conjuntas, para os caracteres altura da planta na maturação (AM), acamamento ( $A C)$, número de dias para maturação (DM) e produção de grãos (PG) 
6 Estimativas das variâncias genética aditiva entre linhagens $\left(\hat{\sigma}_{L}^{2}\right)$ e do erro experimental entre parcelas $\left(\hat{\sigma}^{2}\right)$, com seus respectivos intervalos de confiança para os caracteres altura da planta na maturação (AM), acamamento (AC), número de dias para maturação (DM) e produção de grãos (PG), nos anos 1995/96, 1996/97, 1998/99 e 1999/00.

7 Estimativas das variâncias genética aditiva entre linhagens $\left(\hat{\sigma}_{\mathrm{L}}^{2}\right)$, da interação entre linhagens e anos $\left(\hat{\sigma}_{\mathrm{LA}}^{2}\right)$ e do erro experimental entre parcelas $\left(\hat{\sigma}^{2}\right)$, com seus respectivos intervalos de confiança para os caracteres altura da planta na maturação ( $A M)$, acamamento ( $A C)$, número de dias para maturação (DM) e produção de grãos (PG), obtidas das análises de variância conjuntas dos quatro anos.

8 Estimativas dos coeficientes de herdabilidade no sentido restrito entre médias de linhagens $\left(h_{\bar{x}}^{2} \%\right)$ e seus respectivos intervalos de confiança, em cada um dos anos de experimentação e nas análises conjuntas, para os caracteres altura da planta na maturação (AM), acamamento ( $A C)$, número de dias para maturação (DM) e produção de grãos (PG)

9 Estimativas dos coeficientes de variação genéticos ( $\mathrm{CVg} \%)$ em cada um dos anos de experimentação e nas análises conjuntas para os caracteres altura da planta na maturação (AM), acamamento $(\mathrm{AC})$, número de dias para maturação (DM) e produção de grãos (PG)

10 Estimativas das covariâncias genéticas aditivas $\left(\operatorname{Cov}_{A}\right)$ e fenotípicas entre médias de linhagens $\left(\operatorname{Cov}_{\bar{F}}\right)$, acima e abaixo da diagonal, respectivamente, em cada um dos anos de experimentação e nas análises conjuntas, entre os caracteres altura da planta na maturação ( $A M)$, acamamento ( $A C)$, número de dias para maturação (DM) e produção de grãos (PG). 
11 Estimativas das correlações genéticas aditivas $\left(\mathrm{r}_{\mathrm{A}(\mathrm{X}, \mathrm{Y})}\right)$ e correlações fenotípicas entre médias de linhagens $\left(r_{\bar{F}(X, Y)}\right)$, acima e abaixo da diagonal, respectivamente, entre os caracteres altura da planta na maturação (AM), acamamento $(A C)$, número de dias para maturação (DM) e produção de grãos (PG), obtidas a partir das análises individuais e conjuntas dos quatro anos de avaliação.

12 Estimativas da média da população original $\left(\bar{X}_{p}\right)$, média das linhagens selecionadas $\left(\bar{X}_{s}\right)$, média das testemunhas $\left(\bar{X}_{t}\right)$, do coeficiente de herdabilidade $\left(h_{\bar{X}}^{2}\right)$, do ganho esperado com seleção $(G s)$, do ganho esperado com seleção em percentual da população original $\left(G_{\mathrm{p}} \%\right)$ e do ganho esperado com seleção em percentual das testemunhas $\left(\mathrm{Gs}_{\mathrm{t}} \%\right)$, para os caracteres altura da planta na maturação ( $\mathrm{AM}$ ) e produção de grãos (PG), com base nos quatro anos de experimentação individualmente e nas médias dos anos 1 e 2; 1, 2 e 3; e 1, 2, 3 e 4 ; considerando uma intensidade de seleção de $20 \%$.

13 Médias das linhagens para o caráter altura da planta na maturação (AM), em $\mathrm{cm} /$ planta, para os quatro anos e para as combinações sucessivas dos anos.........

14 Médias das linhagens para o caráter acamamento (AC), notas de 1 a 5 , para os quatro anos e para as combinações sucessivas dos anos.

15 Médias das linhagens para o caráter dias para maturação (DM), em dias, para os quatro anos e para as combinações sucessivas dos anos.

16 Médias das linhagens para o caráter produção de grãos (PG), em g/parcela, para os quatro anos e para as combinações sucessivas dos anos. 


\title{
ESTIMATIVAS DE PARÂMETROS GENÉTICOS E FENOTÍPICOS DE UMA POPULAÇÃO DE SOJA AVALIADA EM QUATRO ANOS
}

\author{
Autor: HEIKO ROSSMANN \\ Orientador: Prof. Dr. ISAIAS OLÍVIO GERALDI
}

RESUMO

Os objetivos do presente trabalho compreendem o estudo dos efeitos da interação entre genótipos e anos sobre as estimativas de parâmetros genéticos e fenotípicos, tais como: variâncias genéticas e fenotípicas, coeficientes de herdabilidade, coeficientes de correlação genética e fenotípica e ganhos esperados com seleção. O material experimental foi constituído de uma amostra aleatória de 89 linhagens de soja, na geração $\mathrm{F} 7$, de uma população oriunda do cruzamento entre os genitores BR-80-14853 e PI-123439. A população foi avaliada durante quatro anos agrícolas, em Piracicaba, SP, utilizando-se um delineamento experimental em blocos casualizados. O número de repetições variou de 3 a 6 ao longo dos anos de avaliação e as parcelas foram constituídas por linhas de $2 \mathrm{~m}$ de comprimento espaçadas de $0,50 \mathrm{~m}$, contendo 35 plantas no estande ideal. Os experimentos incluíram, além das linhagens, as testemunhas IAC-12, IAC-Foscarin-31 e a IAS-5. Foram avaliados os caracteres número de dias para a maturação, altura das plantas na maturação, acamamento e produção de grãos. Detectou-se a presença de grande variabilidade genética entre linhagens para altura das plantas na maturação, produção de grãos e acamamento, indicando boas perspectivas de ganhos com seleção. A interação entre genótipos e anos foi também altamente significativa, provocando mudanças na classificação das linhagens ao longo dos anos. A magnitude da variância da interação entre linhagens e anos foi menor que a da variância genética entre linhagens para altura das plantas e acamamento, ao contrário dos outros dois caracteres, onde as duas variâncias apresentaram magnitude semelhante, indicando que os caracteres dias para 
maturação e produção de grãos são mais sujeitos às oscilações decorrentes das interações com anos. Devido a isso, observou-se uma inconsistência para as estimativas dos diversos parâmetros (herdabilidade, correlações genéticas e fenotípicas e ganhos esperados com seleção) entre os diversos anos, principalmente para a produção de grãos e dias para maturação, indicando que para caracteres muito sujeitos às interações entre genótipos e ambientes, as estimativas de parâmetros genéticos e fenotípicos obtidas a partir de dados experimentais oriundos de apenas um ano de avaliação podem acarretar erros graves na interpretação dos resultados e tomada de decisão relacionados com a seleção de genótipos superiores. 


\title{
ESTIMATES OF GENETIC AND PHENOTYPIC PARAMETERS FROM A SOYBEAN POPULATION EVALUATED OVER FOUR YEARS
}

\author{
Author: HEIKO ROSSMANN \\ Adviser: Prof. Dr. ISAIAS OLÍVIO GERALDI
}

SUMMARY

This paper was carried out in order to study the genotype by year interaction effects on the genetic and phenotypic parameters as: genetic and environmental variances, heritability, genetic and phenotypic correlation and expected response to selection. Experimental material comprised 89 random inbred lines in the F7 generation from a soybean population derived from the cross between the BR-80-14853 and $\mathrm{PI}-123439$ parents. Three to six replications were used over the years and plots comprised a row 2-m long spaced 0.50-m apart with 35 plants after thinning. Two commercial checks were included in the experiments: IAC-12, IAC-Foscarin 31 and IAS-5. The following traits were evaluated: days to maturity, plant height, lodging and grain yield. For plant height, lodging and grain yield a large amount of genetic variability among lines was detected. Genotype by year interaction was highly significant in the analysis of variance, leading to changes in the line ranking over the years. For plant height and lodging, the magnitude of the genotype by year variance was lower than the genetic variance among lines, while for days to maturity and grain yield the magnitude of both variances was similar, indicating that these traits are more influenced by the genotype by year interaction. As a consequence, the estimates of the parameters (heritabilities, genetic and phenotypic correlations and expected responses to selection) were different over the years, mainly for grain yield and days to maturity. These indicates that for this traits, estimates of genetic and phenotypic parameters based on only one year of experimental evaluation can lead to a misinterpretation of the results and consequently to mistaken decisions related with the genotype selection. 


\section{INTRODUÇÃO}

A soja [Glycine max (L.) Merrill] é a mais importante espécie oleaginosa cultivada no mundo e um dos principais produtos agrícolas brasileiros. $O$ interesse pela cultura se deve, principalmente, à sua qualidade nutricional, uma vez que apresenta teores de proteína e óleo elevados (em torno de $40 \%$ e $20 \%$, respectivamente).

A pesquisa em genética e melhoramento tem contribuído significativamente para o sucesso da cultura da soja no Brasil. Os ganhos em produtividade associados à expansão das fronteiras agrícolas, especialmente para as áreas de cerrados, são provas do benefício proporcionado pela obtenção de genótipos mais produtivos e adaptados a diferentes ambientes.

A obtenção de estimativas de parâmetros genéticos e fenotípicos, tais como herdabilidades, correlações genéticas e fenotípicas e ganhos esperados com seleção, têm importância muito grande em programas de melhoramento genético, pois possibilitam a tomada de decisões relacionadas com a escolha do método mais apropriado, os caracteres que devem ser selecionados em etapas iniciais e avançadas de um programa e também o peso que deve ser atribuído a cada caráter, separadamente ou em conjunto.

Estimativas de parâmetros genéticos e fenotípicos freqüentemente são obtidas a partir de dados experimentais oriundos de um ambiente apenas (local ou ano). Entretanto, devido a problemas relacionados com a interação entre genótipos e ambientes, muitas vezes tais estimativas refletem uma situação específica (local e ano), não podendo ser extrapolada para ambientes diferentes. Esse problema é particularmente sério em relação a anos, visto que este fator não tem natureza preditiva. Nesse caso, torna-se muito importante a obtenção de estimativas de parâmetros genéticos e fenotípicos isentas dos componentes da interação com anos, que irão refletir mais fielmente as condições de um ano qualquer. 
Tendo em vista esses fatos, este trabalho tem como objetivos, a partir de uma população de soja:

a) obter estimativas de parâmetros genéticos e fenotípicos, tais como: variâncias genéticas e fenotípicas, coeficientes de herdabilidade, correlações genéticas e fenotípicas e ganhos esperados com seleção;

b) determinar a influência dos componentes da interação entre genótipos e anos sobre as estimativas de parâmetros genéticos e fenotípicos;

c) fornecer subsídios para programas de melhoramento genético visando contornar os problemas decorrentes da interação entre genótipos e anos. 


\section{REVISÃO DE LITERATURA}

O conhecimento dos componentes da variabilidade fenotípica, resultado da ação conjunta dos efeitos genéticos e do ambiente, é de grande importância para a escolha dos métodos de melhoramento, dos locais para a condução dos experimentos, do número de repetições e para a predição dos ganhos com seleção. Os efeitos ambientais mascaram o mérito genético dos indivíduos; assim, quanto maior a proporção da variabilidade decorrente dos efeitos de ambiente em relação à variabilidade total, maior esforço deverá ser despendido na seleção dos genótipos superiores (Borém, 1998).

A variabilidade fenotípica pode ser conhecida por meio das estimativas de herdabilidade, dos coeficientes de correlação fenotípica, genotípica e ambiental, das variâncias genotípicas e fenotípicas, entre outros parâmetros genéticos, que refletem a natureza do material genético e a ação do ambiente, permitindo assim, a predição dos ganhos decorrentes da seleção e a definição das estratégias de melhoramento que devem ser adotadas.

Genótipos cultivados em diferentes ambientes podem ter desempenhos relativos distintos, isto é, um genótipo pode ser extremamente produtivo em um ambiente, enquanto um outro, mais produtivo em outro ambiente, não se sobressai neste. Esta alteração na performance relativa dos genótipos, em virtude das diferenças existentes entre ambientes denomina-se interação genótipo x ambiente (Borém, 1998). A interação se reflete nessa não consistência no desempenho dos genótipos nos vários ambientes, e pode ser detectada pela avaliação em dois ou mais ambientes contrastantes.

Assim sendo, o conhecimento da magnitude das estimativas de herdabilidade, dos coeficientes de correlação genética e fenotípica, e das estimativas de ganho esperado com seleção, e as implicações dos efeitos ambientais sobre estas estimativas, refletidas na interação entre genótipos e ambientes, são de fundamental importância para a condução de um programa de melhoramento e a tomada de decisões. 


\subsection{Herdabilidade}

O conceito de herdabilidade, introduzido para separar as diferenças genéticas e não-genéticas entre indivíduos, é de fundamental importância para a estimação dos ganhos genéticos e para a escolha dos métodos de seleção a serem aplicados (Reis, 2000). Jacquard (1983) apresentou três princípios para definição de herdabilidade: (1) como medida de semelhança entre pai e filho, (2) porção genética no sentido amplo e (3) porção genética no sentido restrito, e ainda ressaltou que a herdabilidade não caracteriza o caráter, mas sim a estrutura da população estudada.

A herdabilidade reflete a proporção da variação fenotípica que pode ser herdada, ou seja, quantifica a confiabilidade do valor fenotípico como guia para o valor genético. Apenas o valor fenotípico de um indivíduo pode ser mensurado, porém, é o valor genético que influenciará a próxima geração. Sendo assim, é importante o conhecimento de quanto da variação fenotípica é atribuída à variação genotípica e este é medido pela herdabilidade (Falconer \& Mackay, 1996). Quando a herdabilidade é alta, a seleção nas gerações iniciais de autofecundação é eficaz. Por outro lado, sendo o seu valor baixo, a seleção deve ser praticada apenas nas gerações mais avançadas, uma vez que o aumento da homozigose, conseqüência da autofecundação, propicia um incremento na herdabilidade no sentido restrito (Robinson, 1963; Falconer \& Mackay, 1996; Fehr, 1987).

Pela sua importância, a herdabilidade deve ser conhecida para a condução de um programa de melhoramento, e muitas decisões práticas são tomadas em função de sua magnitude. A predição do ganho com seleção antes da sua realização, servindo de subsídio para a definição da estratégia de seleção, é uma utilidade direta do valor da herdabilidade no sentido restrito (Fehr, 1987; Ramalho et al., 1993).

A herdabilidade é representada pelo símbolo $\mathrm{h}^{2}$. Este símbolo deriva da terminologia de Wright (1921). É possível estimar dois tipos de herdabilidade: herdabilidade no sentido amplo - $\mathrm{h}_{\mathrm{a}}^{2}$; e herdabilidade no sentido restrito $-h_{r}^{2}$. No sentido amplo, a herdabilidade pode ser definida como a razão da variância genotípica pela variância fenotípica, enquanto que, no sentido restrito, a razão da variância genética aditiva pela variância fenotípica. Portanto, a diferença está no numerador da fração (Allard, 1971; Falconer \& Mackay, 1996). 
O coeficiente de herdabilidade, tanto no sentido restrito como no sentido amplo, pode variar de zero a um. No caso de $h^{2}=1$, as diferenças fenotípicas entre os indivíduos são causadas unicamente por diferenças genéticas entre os mesmos. Quando $h^{2}=0$, significa que a variabilidade do caráter não tem origem genética. Neste caso não existe correlação alguma entre valor genético e valor fenotípico da unidade de seleção (Allard, 1971).

A herdabilidade no sentido restrito é mais útil, uma vez que ela quantifica a importância relativa da proporção aditiva da variância genética, que pode ser transmitida para a próxima geração (Borém, 1998). A herdabilidade no sentido amplo assume maior importância em plantas de propagação vegetativa, nas quais o genótipo é herdado integralmente pelos descendentes. A herdabilidade no sentido amplo pode ser considerada o limite superior da herdabilidade no sentido restrito, sendo esta última utilizada para estimar o ganho efetivo do processo de seleção. Assim, em gerações avançadas de endogamia, devido à homozigose resultante das sucessivas autofecundações, espera-se que a herdabilidade do sentido amplo e a herdabilidade no sentido restrito sejam praticamente iguais (Hanson, 1963).

Segundo Falconer \& Mackay (1996), uma função importante da herdabilidade no sentido restrito é seu papel na predição de ganho devido à seleção, expressando-se a confiança do valor fenotípico como estimador do valor genético. No entanto, deve-se atentar para a avaliação desses coeficientes, pois maiores respostas à seleção não estão, necessariamente, associadas à caracteres de maior herdabilidade, uma vez que altos valores de herdabilidade podem ocorrer em caracteres de pequena variância genética aditiva, desde que a influência do ambiente no caráter seja pequena. O importante na avaliação da herdabilidade, como indicativo da predição, é saber quanto do diferencial de seleção se espera ganhar, em virtude da seleção, na geração seguinte. Assim, para os caracteres que apresentam alto coeficiente de herdabilidade restrita associado a um diferencial de seleção elevado, espera-se maior ganho com seleção.

Normalmente a herdabilidade é estimada a partir de uma análise de variância. É normal a ocorrência de erros associados às estimativas de herdabilidade e de outros componentes da variância genética. Sendo assim, as estimativas devem ser avaliadas com cuidado. Existe grande faixa de variação nas estimativas da herdabilidade de um mesmo caráter e que pode ser parcialmente atribuída à amostragem, às diferenças populacionais e às diferenças ambientais (Vencovsky, 1970; Pesek \& Baker, 1971; Ramalho et al., 1993). 
Estimativas de herdabilidade obtidas por diferentes pesquisadores e condições experimentais não devem ser comparadas, devido ao fato de fatores como tamanho de parcela, densidade populacional e número de repetições terem influência direta em sua estimativa. Comparações podem ser feitas, desde que as condições experimentais sejam devidamente controladas (Robinson, 1963). As estimativas dos componentes de variância e da herdabilidade somente se aplicam à população que Ihes deu origem e às condições ambientais que influenciaram a população. Qualquer generalização pode resultar em erro. Assim, experimentos com a finalidade de obtenção de estimativas de herdabilidade devem ser conduzidos em um ambiente semelhante ao qual as estimativas serão aplicadas. Neste caso, as estimativas da variância genética não serão inflacionados pelos componentes da variância da interação entre genótipo e ambiente, componentes que estarão incluídos na variância fenotípica (Borém, 1998).

Um trabalho que ilustra bem a recomendação de que não devem ser comparadas estimativas de herdabilidade obtidas em diferentes condições experimentais é o de Mauro et al. (1995). Estes autores estudaram os parâmetros coeficiente de herdabilidade e progresso genético obtido com seleção, utilizando quatro tipos de parcelas experimentais - a saber: (a) parcelas convencionais, (b) parcelas na forma de linhas únicas, (c) parcelas na forma de covas, e (d) parcelas constituídas por mistura de igual quantidade de sementes dos genótipos empregados nos experimentos. Observaram que as maiores estimativas de herdabilidade e do progresso genético foram obtidas nas parcelas em forma de cova, e as menores, nas parcelas constituídas pela mistura intergenotípica. Houve correspondência entre os valores estimados nas parcelas experimentais convencionais e os obtidos nas parcelas na forma de linhas únicas, sugerindo que, as parcelas em linhas podem substituir as convencionais quando se tem limitação de tempo, de sementes, de espaço e de mão-de-obra. As estimativas do coeficiente de herdabilidade obtidos para altura da planta e produção de grãos, respectivamente, foram: (a) $88,0 \%$ e $19,0 \%$; (b) $85,0 \%$ e $2,0 \%$; (c) $95,0 \%$ e $81,0 \%$; e (d) $74,0 \%$ e $8,0 \%$.

De maneira geral, a produção de grãos é um caráter que apresenta baixa herdabilidade, e pode ser atribuída ao comportamento puramente quantitativo desse caráter, em função do grande número de genes que o controlam, permitindo maior influência ambiental e, consequentemente, uma diminuição da relação entre a variância genética e fenotípica. Diversos autores confirmaram a baixa herdabilidade para este caráter em soja, dentre eles Destro et al. (1987), Triller \& Toledo (1996), Azevedo Filho et al. (1998), Prado (1999), Backes (2000), Mauro et al. (2000) e Toledo et al. (2000). No entanto, outros autores observaram estimativas de 
herdabilidade de moderadas à altas para o caráter produção de grãos (Srivastava \& Jain, 1994; Santos et al., 1995; Taware et al., 1995).

O caráter altura da planta na maturação apresenta, ao contrário da produção de grãos, herdabilidade mais elevada. Backes (2000), avaliando cinco populações de soja, três na geração $F_{6}$ e duas na $F_{5}$, utilizando um esquema experimental de famílias intercaladas de progenitores, obteve estimativas de herdabilidade no sentido restrito entre famílias variando de $59,4 \%$ a 92,2\% para este caráter. Santos et al. (1995), Triller \& Toledo (1996), Taware et al. (1997), Azevedo Filho et al. (1998), Prado (1999), Azevedo (2000) e Mauro et al. (2000) também obtiveram estimativas de moderadas a altas para o caráter altura da planta.

Assim como altura da planta na maturação, número de dias para maturação é um caráter de herdabilidade mais elevada. Backes (2000) obteve estimativas no sentido restrito variando de 44,5\% a 77,7\% para este caráter. Taware et al. (1995), Taware et al. (1997) e Azevedo (2000) também encontraram estimativas de herdabilidade elevadas para o caráter dias para maturação.

Prado (1994), buscando estabelecer estratégias para o melhoramento conjunto para teor de proteína e produção de grãos, avaliou quatro cruzamentos biparentais de soja na geração $F_{8}$. Obteve estimativas de herdabilidade no sentido restrito com base em médias para o caráter produção de grãos variando de $47,9 \%$ a $61,2 \%$. Para altura da planta na maturação, as estimativas do coeficiente de herdabilidade com base em médias variaram de 58,5\% a 94,7\%. Para número de dias para maturação observou variação de $46,6 \%$ a $83,7 \%$, e para o caráter acamamento, de $28,6 \%$ a $84,9 \%$.

Em geral, a seleção é praticada com base em dados de apenas um ano e um local, mas, sendo a interação genótipo e ambiente significativa, faz-se necessário a utilização de mais de um ano e um local para a obtenção de estimativas de herdabilidade livres dos componentes da interação entre genótipo e ambiente (Borém, 1998).

Pucinelli (1997), utilizou oito linhagens de soja num esquema dialélico, com o objetivo de avaliar o potencial genético das mesmas e a possibilidade de seleção de genitores para programas de cruzamentos em gerações precoces. Observou que, no cruzamento que originou a população utilizada no trabalho, as estimativas de herdabilidade variaram de $42,0 \%$ a $83,0 \%$ nas análises individuais dos quatro anos de experimentação, e foi de $69,0 \%$ na análise conjunta, para o 
caráter produção de grãos. Para altura da planta na maturação, as estimativas, nas análises individuais, variaram de $49,0 \%$ a $68,0 \%$, e na conjunta, foi de $63,0 \%$. A análise conjunta dos quatro anos de experimentação fornece estimativas dos coeficientes de herdabilidade livres dos efeitos da interação entre genótipo e ambiente (anos, neste caso). Nota-se, por meio da observação das estimativas obtidas em cada ano e na análise conjunta, que o caráter produção de grãos é mais influenciado pelo ambiente do que altura da planta.

Vários autores também estudaram os efeitos da interação genótipo $x$ ambiente sob outros pontos de vista menos habituais, envolvendo nutrição mineral de plantas, fertilidade do solo e fitopatologia. Graham et al. (1995) diante do problema da deficiência de manganês em soja, nos solos com pH elevado, obtiveram baixa estimativa de herdabilidade no sentido restrito (19,0\%) na geração $F_{2}$, indicando que as diferenças fenotípicas podem ser atribuídas às variações de ordem ambiental. Por outro lado, a herdabilidade no sentido restrito para a geração $F_{2: 3}$ foi alta $(70,0 \%)$, indicando que a seleção com base na média das famílias $F_{2: 3}$ pode ser utilizada na seleção para tolerância à deficiência de manganês.

Akhter \& Sneller (1996) utilizaram linhagens de soja derivadas de $F_{4}$, pertencentes ao grupo de maturidade IV, para estudar a interação entre genótipo e data de plantio durante três anos. Observaram que a interação genótipo $x$ data de plantio foi significativa para os caracteres altura da planta na maturação, número de nós e dias para maturação, quando contrastados os plantios de abril e junho das linhagens de crescimento indeterminado. Em geral, as estimativas de herdabilidade observadas foram maiores para os plantios de abril e maio do que as de junho. A correlação genética da altura da planta com a produção foi maior nos plantios realizados mais cedo do que os mais tardios, indicando que a seleção indireta para produção de grãos sobre altura da planta ou número de nós pode ser maior nos plantios precoces.

Triller \& Toledo (1996), estudando a predição do potencial genético de cruzamentos em soja para gerar linhagens com desempenho superior ou inferior às referências escolhidas, utilizaram a média e a variância de famílias na geração $F_{3}$. Observaram que as predições ajudaram na seleção entre cruzamentos, independente da herança do caráter e da sua herdabilidade, na ausência dos efeitos da interação genótipo $x$ ambiente. Na presença de interação, o uso de mais de uma referência e, principalmente, de dados oriundos de dois ambientes aumentaram a precisão das estimativas de produção para o caráter produtividade. 
Sneller \& Dombek (1997) estudaram o impacto da irrigação em ambientes secos na seleção para produtividade em soja, buscando entender a interação cultivar x irrigação e a tolerância à seca em soja. Foram analisados sete conjuntos de dados, cada um contendo dados de ensaios irrigados e não-irrigados para um local em dois anos consecutivos de seca. Simularam os efeitos da seleção sobre a produtividade em ambos tratamentos, observando que em seis conjuntos de dados a interação genótipo $x$ irrigação foi significativa. Observaram que a herdabilidade entre médias nos ensaios irrigados foram maiores que nos não-irrigados $(74,0 \% \mathrm{e}$ $37,0 \%$, respectivamente). A correlação genética da produção de ensaios irrigados e nãoirrigados de um ano com produção de ensaios não-irrigados em outro ano foram semelhantes, indicando que a seleção em áreas irrigadas poderia aumentar a produtividade em ambientes secos melhor que a seleção praticada diretamente em ambientes não-irrigados.

Azevedo Filho et al. (1998) avaliando linhagens experimentais de soja na geração $F_{7: 6}$, oriundas de 45 cruzamentos dialélicos, em dois locais contrastantes na saturação de alumínio, observaram ampla variação entre os coeficientes de herdabilidade, para um mesmo caráter em diferentes cruzamentos, e atribuíram isso à diversidade genética entre os genitores e ao tipo de resposta às variações ambientais. O caráter número de dias para maturação apresentou maior estimativa de herdabilidade no local com baixa saturação de alumínio, enquanto que para os caracteres altura da planta na maturação e produção de grãos, os valores foram semelhantes nos dois locais, permitindo inferir que o efeito das condições ambientais, principalmente quanto à saturação de alumínio, sobre a herdabilidade, foi dependente do caráter. Obtiveram coeficientes de herdabilidade de 58,0 e $84,0 \%$ para número de dias para a maturação, 64,0 e $62,0 \%$ para altura da planta, e de 38,0 e $38,0 \%$ para produção de grãos, para alta e baixa saturação de alumínio, respectivamente. Spehar (1999), no entanto, obteve estimativas de herdabilidade no sentido restrito para produção de grãos de $35,1 \%$ e $61,7 \%$, respectivamente, sob condição de alta e de baixa disponibilidade de alumínio.

Azevedo (2000), estudando a reação de progênies de soja em relação ao cancro da haste (Diaporthe phaseolorum f. sp. meridionalis), em casas de vegetação por meio da inoculação artificial das progênies, obteve estimativas de herdabilidade no sentido amplo para os caracteres número de dias para maturação $(61,0 \%$ e 98,0\%), altura da planta $(87,0 \%$ e 91,0\%) e produção de grãos (-28,0\% e 73,0\%), nas gerações $F_{7}$ e $F_{8}$, respectivamente, para progênies resistentes do cruzamento 'Doko RC' x 'Hartwig'. A estimativa de herdabilidade alta para produção de grãos pode decorrer do fato das progênies terem sido conduzidas em casa de vegetação, refletindo a influência do ambiente na obtenção destas estimativas. A estimativa de 
herdabilidade negativa $(-0,28)$ na geração $F_{7}$, por sua vez, indica que a variância dessa característica já diminuiu expressivamente ou que a variância ambiental foi superestimada, concordando com o estudo realizado por Cunha (1987), citado por Azevedo (2000), que também obteve estimativas de herdabilidade negativas para alguns caracteres de interesse agronômico em progênies resultantes do mesmo cruzamento, avaliadas também em casa de vegetação.

Mauro et al. (2000), avaliaram 30 linhagens por três anos para os caracteres altura da planta na maturação, altura de inserção da primeira vagem e a produção de grãos. Foram obtidas estimativas de herdabilidade de 46,0\%,29,0\% e 20,0\% para altura da planta, altura de inserção da primeira vagem e produção de grãos, respectivamente. Observaram ainda que o caráter altura da planta foi menos sensível às alterações ambientais do que altura de inserção da primeira vagem e produção de grãos.

Toledo et al. (2000) analisaram quatro linhagens ou cultivares e as populações descendentes $F_{2}, F_{3}, F_{7}, F_{8}, F_{9}$ e $F_{10}$, obtidos em ensaios realizados em 17 ambientes. Os efeitos genéticos aditivos predominaram, e foram detectados níveis significativos de dominância, além de outros efeitos genéticos, como: epistasia, ligação gênica e interações entre genótipo e ambiente. A baixa herdabilidade $(29,0 \%$, no sentido restrito) do caráter produção de grãos e os consideráveis níveis de interação entre genótipo e ambiente exigem que a avaliação da produtividade seja criteriosamente realizada para haver progresso genético por seleção.

Apesar das diferenças nas herdabilidades de uma certa característica, as estimativas existentes na literatura mostram que cada caráter apresenta uma amplitude de valores que the é peculiar (Ramalho et al., 2000). Assim, as estimativas de herdabilidade podem variar com a característica, o método de estimação, a diversidade da população, o nível de endogamia da população, o tamanho da amostra avaliada, o número e tipo de ambiente considerados, a unidade experimental e a precisão na condução do experimento e da coleta dos dados (Borém, 1998). 


\subsection{Correlações entre caracteres}

Correlação é uma medida da intensidade de associação entre duas variáveis, ou uma medida do grau de variação conjunta de duas variáveis, podendo ser positiva ou negativa, quando ocorre aumento nas duas variáveis ou acréscimo de uma e decréscimo de outra, respectivamente (Steel \& Torrie, 1980).

O conhecimento da associação entre caracteres é de grande importância nos trabalhos de melhoramento vegetal, principalmente se um dos caracteres apresenta baixa herdabilidade, e, ou, problemas para identificação e avaliação. Dessa forma, a seleção correlacionada com um caráter de alta herdabilidade e de fácil mensuração pode ser mais conveniente e conduzir a progressos mais rápidos no melhoramento (Cruz \& Regazzi, 1994).

Estudos genéticos são necessários para distinguir duas causas da correlação entre caracteres, a genética e a ambiental. A principal causa de correlação genética é o pleiotropismo, que é a propriedade pela qual um gene afeta duas ou mais características. Assim, se o gene estiver segregando causará variação simultânea nos dois caracteres. O desequilíbrio de ligação gênica também é uma das causas de correlação entre caracteres, porém é transitória, ocorrendo principalmente em populações oriundas de cruzamentos divergentes. Essa correlação será maior quanto mais próximos estiverem os genes no cromossomo, aumentando a possibilidade de permanecerem juntos mesmo após a autofecundação, mantendo-se assim a correlação entre eles (Falconer \& Mackay, 1996; Ramalho et al., 1993). O ambiente torna-se uma causa de correlação entre duas características quando estas são influenciadas pelas mesmas variações nas condições ambientais. Valores negativos desta correlação indicam que o ambiente favorece um caráter em detrimento do outro, e valores positivos indicam que os dois caracteres são beneficiados ou prejudicados pelas mesmas causas de variações ambientais (Cruz \& Regazzi, 1994).

A correlação fenotípica pode ser diretamente mensurada, a partir de dois caracteres, em certo número de indivíduos da população. Essa correlação tem causas genéticas e ambientais, porém, só a genética envolve uma associação de natureza herdável, podendo, por conseguinte, ser utilizada em programas de melhoramento. As correlações genéticas e ambientais para um mesmo caráter são freqüentemente muito diferentes em magnitude e eventualmente diferentes de sinal. Isto indica que as causas da variação genética e de ambiente afetam os caracteres por meio de mecanismos fisiológicos diferentes (Falconer \& Mackay, 1996). 
Se dois caracteres apresentam correlação genética favorável, é possível obter ganhos para um deles por meio da seleção indireta no outro associado. Em alguns casos, a seleção indireta, com base na resposta correlacionada, pode levar a progressos mais rápidos do que a seleção direta do caráter desejado. Entretanto, se um caráter correlacionar-se negativamente com alguns e positivamente com outros, deve-se tomar o cuidado de, ao selecionar esse, não provocar mudanças indesejáveis em outros (Falconer \& Mackay, 1996).

O conhecimento das correlações genéticas existentes entre os caracteres é de grande importância no melhoramento genético, de forma que, quando a seleção é praticada para um caráter em particular, pode-se fazer inferências da maneira pela qual este caráter afetará os demais (Burton, 1987). Sendo assim, alguns programas de melhoramento de soja vêm tentando associar a seleção de genótipos mais produtivos com maiores teores de proteína e de óleo, por exemplo. Porém, são encontradas dificuldades devido a correlação genética negativa existente entre os caracteres produção de grãos e teor de proteína, indicando que a seleção para um caráter pode resultar em declínio do outro.

Johnson et al. (1955) obtiveram estimativas das correlações genotípicas e fenotípicas para as combinações entre 24 caracteres. O estudo envolveu duas populações segregantes obtidas de cruzamentos biparentais avaliadas na geração $F_{4}$, em dois e três locais, respectivamente. Foram encontradas correlações genéticas e fenotípicas entre porcentagem de óleo e proteína da ordem de $-0,70$ e -0.69 para uma das populações, e de $-0,48$ e $-0,48$ para a outra. As correlações entre porcentagem de proteína e produção de grãos foram de $-0,12$ e -0,08 para a primeira e $-0,64$ e $-0,33$ para a segunda população. A correlação genética entre a produção de grãos e grau de debulha, por sua vez, foi de $+0,47$ e $+0,87$, respectivamente, para a primeira e segunda populações. A seleção de plantas resistentes à debulha eliminaria genótipos com alto teor de proteína, já que a seleção para resistência à debulha pode ser realizada em $F_{2}$ e $F_{3}$, enquanto que a seleção para proteína de $\mathrm{F}_{4}$ em diante. Dentre as correlações estimadas, algumas podem ser destacadas pela sua magnitude e o seu valor prático, tais como: produção de grãos com ciclo $(+0,26$ a $+0,75)$, com resistência à debulha $(+0,23$ a $+0,37)$ e com acamamento $(-0,05$ a $-0,13)$; teor de proteína com teor de óleo $(-0,48$ a $-0,70)$ e com resistência à debulha $(-0,34 \mathrm{a}-0,63)$; e teor de óleo com florescimento $(-0,24 \mathrm{a}-0,27)$ e com dias para maturação $(-0,16 \mathrm{a}-0,22)$.

Dificuldades na obtenção de cultivares que sejam, ao mesmo tempo, altamente produtivos e apresentem alto teor de proteína e óleo foram relatadas por outros autores, dentre eles: Sebern 
\& Lambert (1984), Marschalek (1995), Liu et al. (1995), Pantalone et al. (1996), Taware et al. (1997), Li et al. (18 Ago 2001) e Qi \& Wang (18 Ago 2001). No entanto alguns estudos mostram ser possível a obtenção de cultivares que sejam produtivos e apresentem simultaneamente alto teor de proteína e óleo. Simpson \& Wilcox (1983), Burton (1987), Wehrmann et al. (1987) e Huang \& Tong (1990), ilustram bem isso em seus trabalhos.

Simpson \& Wilcox (1983), avaliaram os caracteres produção de grãos, teor de proteína, teor de óleo e outras características agronômicas em 412 progênies de soja resultantes de quatro cruzamentos envolvendo duas linhagens pouco adaptadas, mas de alto teor protéico, e obtiveram estimativas de correlações genéticas avaliadas nas gerações $F_{6}$ e $F_{7}$. A correlação genética entre produção de grãos e teor de proteína variou de $-0,75 \mathrm{a}+0,54$; entre produção e teor de óleo, de -0,27 a +0,25;e entre teor de proteína e teor de óleo, de -0,96 a -0,15. O alto teor protéico também foi correlacionado significativamente com maturidade tardia, variando de $+0,19 \mathrm{a}+0,44$.

Burton (1987) apresenta diversas correlações entre produção de grãos e outros caracteres, de diversos trabalhos de outros autores. As correlações genéticas entre produção e teor de proteína variaram de $-0,74$ a $+0,35$, e as correlações entre produção e teor de óleo variaram de $-0,27$ a $+0,45$, sendo evidente que a magnitude e a direção das correlações depende da população nos quais os caracteres estão sendo mensurados.

Wehrmann et al. (1987), conseguiram transferir a característica de alto teor de proteína para uma cultivar de elevada produção de grãos e baixo teor protéico. Para isso, cruzaram uma linhagem (PI) de soja que apresentava baixa produção de grãos e elevado teor protéico (48\%) com três linhagens com alta produção de grãos e teor médio de proteína de $40 \%$. A seleção para teor de proteína foi praticada durante duas gerações de retrocruzamento para o parental de alta produção de grãos.

Huang \& Tong (1990), analisando acessos de soja selvagem (Glycine soja) e semi-selvagem, verificaram que o teor de proteína apresentava correlação positiva com o teor de óleo em ambos os tipos, selvagem $(+0,14)$ e semi-selvagem $(+0,62)$. Concluíram então que a seleção para altos teores de proteína e óleo seria mais fácil de ser obtida em genótipos semi-selvagens. 
Uma série de estudos de correlação envolvendo os caracteres produção de grãos, altura da planta na maturação, número de dias para o florescimento, número de dias para a maturação e acamamento, dentre outros de importância agronômica, são encontrados também na literatura.

Santos et al. (1995), avaliando progênies $F_{6}$ de soja, oriundas de seleções realizadas entre famílias $F_{5}$ do cruzamento 'FT-Cometa' $x$ 'IAC-8', obteve estimativas dos coeficientes de correlação genotípica e fenotípica entre 10 caracteres. Observaram que as correlações genotípicas apresentaram valores superiores às respectivas correlações fenotípicas, indicando interferência do ambiente como fator perturbador na seleção indireta. Obtiveram coeficientes de correlação fenotípica e genotípica entre produção de grãos e número de dias para maturação de $+0,58$ e $+0,86$, entre produção e altura da planta na maturação de $+0,34$ e $+0,40$, e entre dias para maturação e altura da planta de $+0,42$ e $+0,52$, respectivamente. $O$ caráter produção de grãos apresentou também correlação genotípica positiva com todos os demais caracteres avaliados.

Taware et al. (1995), em seu estudos sobre a variabilidade fenotípica existente em variedades de soja, constataram que o caráter produção de grãos estava correlacionada positivamente com dias para o florescimento $(+0,53)$, dias para maturação $(+0,54)$ e número de vagens por planta $(+0,56)$.

Board et al. (1997) estudaram métodos de análise para avaliação dos componentes de produção como potenciais critérios de seleção, durante um período de cinco anos. Número de sementes, número de vagens e vagens por nó reprodutivo, mostraram correlações fenotípicas positivas com produção $(+0,53,+0,59$ e $+0,76$, respectivamente). Entretanto, número de sementes não se mostrou promissor como critério de seleção indireto no nível genotípico. A correlação genética entre número de sementes e produção $(+0,01)$ foi não significativa e o efeito direto do número de sementes na produção seria menor quando comparado com vagens por nó reprodutivo $(+0,33)$, número de vagens $(+0,11)$, percentagem de nós reprodutivos $(+0,30)$ e tamanho da semente $(+0,33)$.

Backes (2000), estudando cinco populações de soja, obteve estimativas do coeficiente de correlação para os caracteres agronômicos avaliados no florescimento e na maturação. Todos os coeficientes foram positivos e as correlações fenotípicas e genotípicas foram altas (acima de 0,56). Observou ainda que as correlações genotípicas foram superiores às fenotípicas, com exceção da correlação entre altura da planta na floração e altura da planta na maturação na 
população I. Este comportamento ocorre quando pelo menos um dos caracteres envolvidos possui alta herdabilidade. Backes cita que vários outros autores observaram correlações genotípicas maiores que as fenotípicas em soja, como Jonhson et al. (1955), Kaw \& Menon (1972), Moro (1990), Santos (1994), Oliveira (1996) e Souza (1998). Backes obteve coeficientes de correlação entre altura da planta na maturação e produção de grãos variando de $+0,02$ a $+0,48$ (genético) e $+0,03$ a +0,33 (fenotípico); e entre dias para maturação e produção de grãos variando de $-0,23 \mathrm{a}+0,74$ (genético) e de $-0,21 \mathrm{a}+0,18$ (fenotípico).

O estudo das correlações entre caracteres pode ser aplicado também em pesquisas com diferentes finalidades, como as que envolvem nodulação e acúmulo e distribuição de nitrogênio (Pazdernik et al., 1997), associação de marcadores de DNA com os locos que controlam as concentrações de óleo e proteína nos grãos (Qiu et al., 1997), redução do conteúdo de ácidos graxos saturados (Rebetzke et al., 1998), efeito da maturação precoce sobre a germinabilidade da soja (Tyler, 1999), mecanismos de resistência à doença (Kim \& Diers, 2000) e desenvolvimento de variedades com habilidade de supressão a plantas daninhas (Jannink et al., 2000).

Ao longo dos anos, diversos autores estudaram as correlações existentes entre diferentes caracteres em soja. Monteverde (1984), citado por Marschalek (1995), foi além, e, a partir dos estudos das correlações genéticas e fenotípicas entre produção de grãos e teor de proteína em três populações, sugeriu que as estimativas de variâncias e covariâncias genéticas estariam inflacionadas pelas interações existentes entre genótipos $x$ locais, genótipos $x$ anos e genótipos $x$ locais $x$ anos. As correlações fenotípicas entre estes dois caracteres foram de +0,07, -0,05 e0,25 para as populações 1, 2 e 3, respectivamente. Entretanto, as correlações genéticas entre estes dois caracteres foram positivas e altas, isto é: $+0,49,+0,33$ e $+0,58$. Monteverde ressaltou a necessidade de se remover os componentes de variância associados com a interação entre locais e anos em populações similares para identificar com maior precisão a natureza das correlações genéticas entre produção de grãos e teor de proteína, afim de melhorar as estimativas dos coeficientes de correlação.

Pantalone et al. (1996) utilizaram uma população de soja na geração $F_{2}$, oriunda do cruzamento entre uma cultivar e a PI 416937, tolerante à seca, que foi introduzida com o objetivo de aumentar a resistência à estiagem em soja. A interação genótipo $x$ ambiente foi significativa em todos os tratamentos, indicando que a performance relativa entre ambientes é inconsistente entre os genótipos. A interação para escore da raiz foi expressa nas alterações na classificação 
das progênies. Estes autores ressaltaram a importância de serem realizadas avaliações em diferentes locais para serem melhor distinguidas as diferenças entre os genótipos e selecionadas as melhores progênies.

Gieco (1997), buscou quantificar os componentes da interação genótipo x ambiente em progênies provenientes de cruzamentos biparentais de soja e quais as suas implicações no melhoramento, avaliando três populações oriundas de cruzamentos biparentais durante três anos agrícolas. Obteve, utilizando médias de progênies, estimativas dos coeficientes de correlação genético e fenotípico entre anos para o caráter produção de grãos, observando grande variação na magnitude destas estimativas, mostrando os efeitos da interação entre genótipos e anos. A interação genótipo $x$ ambiente foi altamente significativa para todas as populações avaliadas e o componente complexo da interação foi predominante, sugerindo que a seleção deve ser aplicada com base nas médias das progênies de mais de um ano de experimentação, o que permite a retenção das linhagens consistentemente mais produtivas no programa de melhoramento.

Azevedo Filho et al. (1998) avaliaram 900 linhagens $\left(F_{6: 7}\right)$ de soja, oriundas de 45 cruzamentos dialélicos, em dois locais contrastantes em saturação de alumínio. Observaram que as correlações fenotípicas e genotípicas entre os caracteres foram positivas e maiores no local com maior saturação de alumínio, e que, em geral, as correlações genotípicas foram superiores às fenotípicas, indicando que a expressão fenotípica da associação entre caracteres é alterada frente às interferências do ambiente, dificultando o processo de seleção. As estimativas dos coeficientes de correlação fenotípica e genotípica foram de $+0,27$ e $+0,54$ entre os caracteres número de dias para maturação e altura da planta na maturação; +0,30 e +0,54 entre dias para maturação e produção de grãos; e +0,39 e +0,62 entre altura da planta e produção, respectivamente, para o local com alta saturação de alumínio. Para o local que apresentava baixa saturação de alumínio, as estimativas foram $+0,34$ e $+0,43$ entre dias para maturação e altura da planta; +0,03 e +0,11 entre dias para maturação e produção de grãos; e +0,28 e +0,07 entre altura da planta e produção.

Vollmann et al. (2000) estudando soja na Europa Central, observaram que a variação no conteúdo de proteína sofria influências sazonais. Em genótipos mais precoces o teor de proteína é elevado $(39,9$ a 47,6\%) nos anos com altas temperaturas do ar e taxas moderadas de pluviosidade durante o período de enchimento de grãos, ao passo que o teor de proteína nos grãos é reduzido (26,5 a 34,7\%) drasticamente em épocas de insuficiente fixação de nitrogênio 
ou grandes precipitações durante o período de enchimento de grãos. Apesar de terem feito uma alta modificação no ambiente, com a aplicação de nitrogênio no solo e inoculação de Rizóbio nas sementes, a variação genética do conteúdo de proteína foi considerável e a interação genótipo $x$ ambiente foi de baixa magnitude.

Em geral, existe grande variação nas estimativas de correlações genéticas entre os caracteres em soja, refletindo diferenças existentes entre o grau de associação dos caracteres de uma população para outra. No entanto, com o acúmulo de informações obtidas em programas de melhoramento, tem-se um indicativo da direção e magnitude predominante da correlação entre os principais caracteres. Mesmo assim, os coeficientes de correlação genética devem ser mensurados em cada população para proporcionar maior eficiência na seleção.

Uma das principais aplicações das correlações relaciona-se com a seleção. Com o entendimento de como dois ou mais caracteres estão correlacionados, podemos inferir em quanto a seleção praticada em um caráter $\mathrm{X}$ pode alterar a média de um caráter $\mathrm{Y}$. $\mathrm{A}$ isto denominamos de resposta correlacionada à seleção. O progresso com seleção de um caráter correlacionado pode ser predito sempre que forem conhecidas a correlação genética entre os dois caracteres e a herdabilidade do caráter no qual a seleção é praticada. Além disso, a seleção indireta utilizando um caráter $X$ pode ser mais eficiente para o melhoramento de um caráter $Y$ do que a seleção direta em $Y$, se $X$ tiver uma herdabilidade substancialmente maior $e$ a correlação genética entre os dois for alta (Falconer \& Mackay, 1996).

Sobre o coeficiente de correlação pode-se fazer as seguintes observações: é adimensional e seu valor absoluto não ultrapassa a unidade, tanto positiva quanto negativa; o coeficiente zero reflete a falta de relação linear e não a falta de associação entre duas variáveis; e dois caracteres independentes apresentam coeficiente de correlação nulo, mas coeficiente de correlação nulo não implica que os caracteres sejam independentes (Cruz \& Regazzi, 1994).

Em resumo, os coeficientes de correlação dependem da base genética da população nos quais os caracteres estão sendo mensurados, podendo apresentar uma amplitude de variação entre valores negativos e positivos, e nos fornecem indicativos de como a seleção praticada em um caráter pode influenciar a média de outro. 


\subsection{Ganho esperado com seleção}

A possibilidade de predição dos ganhos obtidos por uma determinada estratégia de seleção constitui-se em uma das principais contribuições da Genética Quantitativa para o melhoramento. Com base nestas informações é possível orientar de maneira mais efetiva o programa de melhoramento, predizer o sucesso do esquema de seleção adotado e determinar, de forma científica, quais as técnicas que podem ser mais eficazes (Cruz \& Regazzi, 1994).

Em geral, os diversos caracteres de importância econômica estão correlacionados entre si, em magnitude e sentidos variados. Tal fato implica que a seleção em um caráter pode proporcionar alterações em outros, podendo ser ou não de interesse para o melhoramento. Assim, a quantificação dos efeitos indiretos da seleção de um caráter sobre outros é fundamental para que se possa orientar programas de melhoramento no sentido de se obter um material genético que reuna, simultaneamente, um conjunto de atributos favoráveis. Com estes conhecimentos é possível a obtenção de progresso em um caráter por seleção em outro, podendo até mesmo ser mais eficiente do que a seleção direta (Cruz \& Regazzi, 1994).

A seleção baseada em uma, ou em poucas características, tem se mostrado inadequada por conduzir a um material genético superior em relação aos caracteres selecionados, mas com desempenho menos favorável em relação aos outros caracteres não considerados no momento da seleção. Assim, uma maneira de se melhorar a eficiência de um programa de melhoramento é a seleção simultânea de um conjunto de caracteres de importância agronômica. A utilização de um índice de seleção neste caso parece ser adequada, pois permite combinar as informações obtidas nas parcelas experimentais, de modo a possibilitar a seleção com base em um conjunto de variáveis que reunam os atributos de interesse (Cruz \& Regazzi, 1994).

O índice de seleção constitui-se num caráter adicional, estabelecido pela combinação ótima de vários caracteres, que permite efetuar, com eficiência, a seleção simultânea de múltiplos caracteres. Comparações com a seleção direta permitem concluir que a utilização de índices como critério de seleção proporciona resultados relativamente superiores. De maneira geral, o ganho sobre o caráter é reduzido, entretanto esta redução é compensada por uma melhor distribuição de ganhos favoráveis nos demais caracteres. Diferentes índices representam diferentes alternativas de seleção e, consequentemente, de ganhos. Eles identificam, de maneira rápida e eficiente, materiais genotípicos que podem ser mais adequados para os propósitos do melhorista (Cruz \& Regazzi, 1994). 
De acordo com Vencovsky (1987), os fatores mais importantes que interferem, direta ou indiretamente, no ganho obtido por seleção são: intensidade de seleção, propriedades genéticas da população e condições ambientais. O ganho obtido por seleção está diretamente relacionado com o diferencial de seleção, ou seja, à diferença entre a média do grupo selecionado e a média da população original. Sendo assim, já que os caracteres quantitativos, como a produção de grãos, apresentam uma distribuição aproximadamente normal, um maior diferencial de seleção é conseguido quando uma menor proporção de unidades superiores (famílias ou indivíduos) é selecionada. Quanto maior a pressão de seleção, maior será o diferencial. No entanto, uma pressão de seleção alta implica em risco de redução drástica na variabilidade genética. Quanto mais heterogênea for uma população, maiores são as chances de ganho com seleção, pois tal ganho se baseia em diferenças genéticas. Outro fator que interfere no ganho por seleção é o ambiente. No caso da produção de grãos em soja, que é uma característica quantitativa, este fator apresenta grande influência na proporção do diferencial de seleção passado à geração seguinte, ou seja, na proporção herdável desse diferencial. Normalmente há uma variação da condição ambiental, quando o experimento é montado no campo, onde não existe controle local, de ano para ano.

A interação entre genótipo e ambiente não interfere apenas na recomendação de cultivares, como também dificulta a seleção de progênies, a estimação correta dos componentes de variância genética e, por sua vez, do ganho esperado com seleção (Ramalho et al., 1993). A ocorrência da interação do tipo complexa entre as progênies de um programa de melhoramento, por exemplo, que é normalmente realizada com base na média dos vários ambientes, pode não garantir a seleção dos genótipos superiores para cada ambiente em particular.

Estudos à respeito da interação genótipos $\mathrm{x}$ ambientes, apesar de serem de grande importância para o melhoramento, não proporcionam informações pormenorizadas sobre o comportamento de cada genótipo frente às variações ambientais. Para tal objetivo, realizam-se análises de adaptabilidade e estabilidade, pelas quais torna-se possível a identificação de cultivares de comportamento previsível e que sejam responsivos às variações ambientais, em condições específicas ou amplas (Cruz \& Regazzi, 1994).

É importante ainda enfatizar que nem sempre a presença de interação implica em diferenças na adaptabilidade dos materiais genéticos. Assim, por exemplo, pode acontecer de se detectar interação devido ao fato dos dados não se ajustarem ao modelo matemático adotado na sua 
análise (Chaves et al., 1989). Por exemplo, a interação simples pode ser detectada numa situação em que o efeito ambiental sobre o material genético ocorra de forma multiplicativa ao invés de aditiva. Assim, será detectada interação significativa, embora esta realmente não ocorra. Nessa situação, a análise dos dados transformados poderá indicar que a interação é não significativa.

Alliprandini et al. (1993) observaram em seu estudo que as associações entre locais e anos constituíam ambientes distintos. A interação entre genótipos e anos foi não-significativa. Observaram que a interação grupos de maturação $x$ locais $x$ anos foi significativa, indicando que, para determinada combinação entre local e ano, existe um grupo de maturação com maior produtividade. Constataram ainda que os genótipos apresentavam respostas diferentes, quando avaliados em diferentes ambientes, nos diversos anos e locais dos ensaios, e que a interação anos x locais foi importante no desempenho dos genótipos, evidenciando a importância dessa interação para os testes de avaliação de linhagens de soja.

Prado (1999), comparando dois métodos de seleção utilizando quatro populações homozigotas de soja, observou a ocorrência de interação entre genótipos e anos, sendo mais pronunciada para o caráter produção de grãos do que para altura da planta na maturação. Observou que o método de seleção Seqüencial propiciou um ganho com seleção maior que o método Independente para ambos os caracteres nas quatro populações. A eficiência do método Seqüencial foi mais acentuada nas populações com menor variabilidade genética e, consequentemente, com menor coeficiente de herdabilidade.

Oliveira et al. (1999) utilizaram diferentes estratégias de seleção para estimar os ganhos esperados em dias para o florescimento e outros caracteres relacionados em duas populações $\mathrm{F}_{2}$ de soja, oriundas do cruzamento entre linhagens com ausência das três isoenzimas lipoxigenases em suas sementes com a cultivar IAC-12, portadora de genes para um período juvenil longo. Uma população foi conduzida em casa de vegetação, com aquecimento. A outra foi conduzida no campo, sob condições naturais de temperatura, e apresentou retardamento no florescimento em função das baixas temperaturas observadas no início do seu desenvolvimento. O florescimento tardio resultou em ganhos com seleção maiores para as plantas que se desenvolveram no campo, comparadas com as da casa de vegetação. $A$ seleção direta em número de dias para o florescimento mostrou ser eficiente para ganho neste caráter em ambas populações, além de propiciar ganhos consideráveis nos outros caracteres mensurados. Os autores concluíram que a temperatura e o fotoperíodo interagem entre si e 
com os genótipos, afetando a época de florescimento, e influencia outros caracteres agronômicos correlacionados, incluindo a produtividade.

Kilgore-Norquest \& Sneller (2000), com o objetivo de determinar se, variando o hábito de crescimento, seria possível aumentar a produtividade de soja em alguns ambientes, utilizaram isolinhas com crescimento determinado e indeterminado, oriundas de dois cruzamentos. Foram avaliadas todas as linhagens e as testemunhas em dois locais por dois anos, com duas datas de plantio e na presença ou ausência de irrigação. Observaram que as diferenças de produtividade entre as linhagens de crescimento determinado e indeterminado foram condicionados por uma interação complexa entre efeitos genéticos e ambientais. As linhagens indeterminadas tiveram uma vantagem em produtividade sobre as de crescimento determinado em ambientes com limitações para produção e potencial de crescimento.

Fica evidente frente aos resultados apresentados nessa revisão a importância do conhecimento da magnitude relativa do componente da interação sobre as estimativas de parâmetros genéticos e fenotípicos e as implicações dessa com a seleção de genótipos. 


\section{MATERIAL E MÉTODOS}

\subsection{O material genético}

O material experimental foi constituído de uma amostra aleatória de 89 linhagens (linhas derivadas de plantas individuais na geração $F_{7}$ ), obtidas pelo método S.S.D., de uma população oriunda do cruzamento entre os genitores BR-80-14853 e PI-123439, cuja descrição está apresentada a seguir (Pimentel, 1991):

BR-80-14853: linhagem brasileira, proveniente da EMBRAPA Soja, com ciclo de produção médio de 158 dias, ciclo aproximado para florescimento de 51 dias, hábito de crescimento indeterminado, flor roxa, semente verde, pubescência marrom e hilo preto.

PI-123439: linhagem norte-americana, fornecida pela EMBRAPA Soja, com ciclo de produção médio de 150 dias, ciclo aproximado de 51 dias para florescimento, hábito de crescimento determinado, flor roxa, semente amarela, pubescência e hilo cinza.

\subsection{Delineamento experimental}

Os experimentos foram conduzidos em solo do tipo terra roxa estruturada série "Luiz de Queiroz" (Ranzani et al., 1966), na área experimental do Departamento de Genética da Escola Superior de Agricultura Luiz de Queiroz, Universidade de São Paulo, no município de Piracicaba, SP, situada a $22^{\circ} 42^{\prime} 30^{\prime \prime}$ de latitude sul e $47^{\circ} 38^{\prime} 00^{\prime \prime}$ de longitude oeste e a $537 \mathrm{~m}$ de altitude. De acordo com a classificação climática de THORNTHWAITE para esta região, a fórmula climática resulta em C2rA'a', ou seja, clima úmido com pequeno déficit hídrico, megatérmico e com vegetação o ano todo. 
A população foi avaliada durante quatro anos agrícolas: 1995/96, 1996/97, 1998/99 e 1999/00; em um delineamento experimental em blocos casualizados modificado, no qual os tratamentos são agrupados em 5 conjuntos, contendo de 17 a 19 linhagens cada um, com um número de repetições variável ao longo dos anos de avaliação, a saber: 3, 4, 6 e 6, respectivamente, para os anos agrícolas na ordem apresentada acima. Os experimentos incluíram, além das linhagens, as testemunhas IAC-12, IAC-Foscarin-31 e a IAS-5. As parcelas experimentais foram constituídas por linhas de 2,0 m de comprimento, espaçadas de 0,50m. A densidade de semeadura foi de 30 sementes por metro linear, com desbaste para cerca de 17 plantas por metro, após a germinação. Os caracteres avaliados ao longo dos anos foram:

a) Número de dias para o florescimento: período correspondente ao número de dias decorridos entre a semeadura e quando mais de $50 \%$ das plantas apresentam flores;

b) Altura das plantas no florescimento: distância $(\mathrm{cm})$ compreendida entre a base e 0 ápice da haste principal, nos primeiros dias do florescimento; são medidas cinco plantas por parcela;

c) Número de dias para a maturação: período que corresponde ao número de dias decorridos desde a semeadura e quando cerca de $95 \%$ das vagens das plantas atingiram a maturidade;

d) Altura das plantas na maturação: distância $(\mathrm{cm})$ da base ao ápice da haste principal, na época da maturação; da mesma forma que para a altura das plantas no florescimento, são medidas cinco plantas por parcela;

e) Acamamento: avaliado na maturação através de uma escala de notas visuais que varia de 1 a 5 , onde a nota 1 corresponde a uma parcela com todas as plantas eretas e a nota 5 a uma parcela com todas as plantas acamadas; e

f) Produção de grãos: avaliada na maturidade através do peso dos grãos (g) de cada parcela.

Contudo, para as finalidades deste trabalho foram utilizadas somente os caracteres altura de planta na maturação ( $\mathrm{AM}$ ), acamamento ( $\mathrm{AC}$ ), número de dias para maturação (DM) e produção de grãos (PG), por se tratarem dos caracteres de maior importância agronômica. 


\subsection{Análise estatística}

As análises de variância individuais para cada ano e as análises de variância conjuntas dos quatro anos de avaliação foram feitas com o auxílio do programa computacional SAS (Statistical Analysis System), desenvolvido pelo SAS Institute Inc. (31 Oct 2001). Com base nestas análises, foram estimadas as variâncias genéticas e fenotípicas, covariâncias genéticas e fenotípicas, as correlações genéticas e fenotípicas entre os quatro caracteres, os coeficientes de herdabilidade e os ganhos esperados com seleção.

\subsubsection{Análises de variância individuais para cada ano de avaliação}

Para as anovas individuais de cada ano de avaliação, o modelo matemático empregado foi o seguinte:

$Y_{i j k}=\mu+t_{i(k)}+b_{j(k)}+c_{k}+e_{(i j) k}$, onde:

$\mathrm{Y}_{\mathrm{ijk}}$ : observação referente ao tratamento i na repetição j no conjunto k;

$\mu$ : média geral;

$t_{i(k)}$ : efeito aleatório de tratamentos (linhagens) dentro de conjuntos, onde $i=1,2,3, \ldots l$;

$b_{j(k)}$ : efeito aleatório de repetições (blocos) dentro de conjuntos, onde $j=1,2,3, \ldots \mathrm{J}$;

$\mathrm{c}_{\mathrm{k}}$ : efeito de conjuntos, onde $\mathrm{k}=1,2,3, \ldots \mathrm{K}$;

$\mathrm{e}_{\mathrm{ijk}}$ : erro experimental associado à parcela ij.

De acordo com este modelo, o esquema de análise de variância é apresentado no Quadro 1. 


\begin{tabular}{|lcccc|}
\hline \multicolumn{1}{|c}{$\mathrm{FV}$} & $\mathrm{GL}$ & $\mathrm{QM}$ & $\mathrm{E}(\mathrm{QM})$ & $\mathrm{F}$ \\
\hline Conjuntos $(\mathrm{C})$ & $(\mathrm{K}-1)$ & $\mathrm{Q}_{4}$ & - & - \\
Blocos/C & $\mathrm{K}(\mathrm{J}-1)$ & $\mathrm{Q}_{3}$ & - & $\mathrm{Q}_{3} / \mathrm{Q}_{1}$ \\
Tratamentos/C & $\mathrm{K}(\mathrm{I}-1)$ & $\mathrm{Q}_{2}$ & $\sigma^{2}+\mathrm{J} \sigma_{\mathrm{T}}^{2}$ & $\mathrm{Q}_{2} / \mathrm{Q}_{1}$ \\
Resíduo/C & $\mathrm{K}(\mathrm{I}-1)(\mathrm{J}-1)$ & $\mathrm{Q}_{1}$ & $\sigma^{2}$ & - \\
\hline
\end{tabular}

Quadro 1 - Esquema das análises de variância individuais.

\subsubsection{Análises de variância conjuntas dos quatro anos de avaliação}

As análises de variância conjuntas dos quatro anos foram baseados no seguinte modelo matemático:

$\mathrm{Y}_{\mathrm{ijkl}}=\mu+\mathrm{t}_{\mathrm{i}(\mathrm{k})}+\mathrm{b}_{\mathrm{j}(\mathrm{kl})}+\mathrm{c}_{\mathrm{k}}+\mathrm{a}_{\mathrm{l}(\mathrm{k})}+\mathrm{ta}_{\mathrm{i}(\mathrm{k})}+\mathrm{e}_{\mathrm{ij}(\mathrm{kl})}$, onde:

$\mathrm{Y}_{\mathrm{ijkl}}$ : observação referente ao tratamento i na repetição j, no conjunto k e no ano I;

$\mu$ : média geral;

$t_{i(k)}$ : efeito aleatório de tratamentos (linhagens) dentro de conjuntos, onde $i=1,2,3, \ldots \mathrm{l}$;

$b_{j(k l)}$ : efeito aleatório de repetições (blocos) dentro de conjuntos, onde $j=1,2,3, \ldots \mathrm{J}$;

$c_{k}$ : efeito aleatório de conjuntos, onde $k=1,2,3, \ldots K$;

$\mathrm{a}_{\mathrm{l}(\mathrm{k})}$ : efeito aleatório de anos dentro de conjuntos, onde $\mathrm{I}=1,2,3, \ldots \mathrm{L}$;

$\mathrm{ta}_{\mathrm{il}(\mathrm{k})}$ : efeito da interação tratamentos $\mathrm{x}$ anos dentro de conjuntos; e

$\mathrm{e}_{\mathrm{ij}(\mathrm{kl})}$ : erro experimental associado à parcela $\mathrm{ij}$, dentro de conjuntos e anos.

O esquema de análise de variância é apresentado no Quadro 2. 


\begin{tabular}{|lcccc|}
\hline \multicolumn{1}{|c}{$\mathrm{FV}$} & $\mathrm{GL}$ & $\mathrm{QM}$ & $\mathrm{E}(\mathrm{QM})$ & $\mathrm{F}$ \\
\hline Conjuntos $(\mathrm{C})$ & $(\mathrm{K}-1)$ & $\mathrm{Q}_{6}$ & - & - \\
Anos $(\mathrm{A}) / \mathrm{C}$ & $\mathrm{K}(\mathrm{L}-1)$ & $\mathrm{Q}_{5}$ & - & - \\
Blocos/A/C & $\mathrm{KL}(\mathrm{J}-1)$ & $\mathrm{Q}_{4}$ & - & - \\
Tratamentos/C & $\mathrm{K}(\mathrm{I}-1)$ & $\mathrm{Q}_{3}$ & $\sigma^{2}+\mathrm{J} \sigma_{\mathrm{TA}}^{2}+\mathrm{JL} \sigma_{\mathrm{T}}^{2}$ & $\mathrm{Q}_{3} / \mathrm{Q}_{1}$ \\
$(\mathrm{~T} \times \mathrm{A}) / \mathrm{C}$ & $\mathrm{K}(\mathrm{I}-1)(\mathrm{L}-1)$ & $\mathrm{Q}_{2}$ & $\sigma^{2}+\mathrm{J} \sigma_{\mathrm{TA}}^{2}$ & $\mathrm{Q}_{2} / \mathrm{Q}_{1}$ \\
Resíduo/A/C & $\mathrm{KL}(\mathrm{I}-1)(\mathrm{J}-1)$ & $\mathrm{Q}_{1}$ & $\sigma^{2}$ & - \\
\hline
\end{tabular}

Quadro 2 - Esquema das análises de variância conjuntas.

\subsubsection{Análises de covariância entre os caracteres}

As análises de covariância entre os caracteres dois a dois seguiram um esquema semelhante ao das análises de variância: análises individuais por ano e análises conjuntas para os vários anos. O esquema das análises de covariância conjuntas é apresentado no Quadro 3.

\begin{tabular}{|lccc|}
\hline \multicolumn{1}{|c}{ FV } & GL & PM & E(PM) \\
\hline Conjuntos $(\mathrm{C})$ & $(\mathrm{K}-1)$ & $\mathrm{P}_{6}$ & - \\
Anos $(\mathrm{A}) / \mathrm{C}$ & $\mathrm{K}(\mathrm{L}-1)$ & $\mathrm{P}_{5}$ & - \\
Blocos/A/C & $\mathrm{KL}(\mathrm{J}-1)$ & $\mathrm{P}_{4}$ & - \\
Tratamentos/C & $\mathrm{K}(\mathrm{I}-1)$ & $\mathrm{P}_{3}$ & $\mathrm{Cov}+\mathrm{JCov}_{\mathrm{TA}}+\mathrm{JLCov}_{\mathrm{T}}$ \\
$(\mathrm{T} \times \mathrm{A}) / \mathrm{C}$ & $\mathrm{K}(\mathrm{I}-1)(\mathrm{L}-1)$ & $\mathrm{P}_{2}$ & ${\text { Cov }+\mathrm{JCov}_{\mathrm{TA}}}$ \\
Resíduo/A/C & $\mathrm{KL}(\mathrm{I}-1)(\mathrm{J}-1)$ & $\mathrm{P}_{1}$ & Cov \\
\hline
\end{tabular}

Quadro 3 - Esquema das análises de covariância conjuntas. 


\subsubsection{Estimação de parâmetros genéticos e fenotípicos}

Com base nas análises de variância e covariância conjuntas (itens 3.3.2 e 3.3.3), foram estimados os parâmetros genéticos e fenotípicos que se seguem:

\subsubsection{Variâncias genéticas e fenotípicas}

$\hat{\sigma}^{2}=Q_{1}$ : variância do erro experimental entre parcelas;

$\hat{\sigma}_{\mathrm{T}}^{2}=\frac{\mathrm{Q}_{3}-\mathrm{Q}_{2}}{\mathrm{JL}}=\hat{\sigma}_{\mathrm{A}}^{2}$ : variância genética entre tratamentos (linhagens), que corresponde à variância genética aditiva;

$\hat{\sigma}_{\mathrm{TA}}^{2}=\frac{\mathrm{Q}_{2}-\mathrm{Q}_{1}}{\mathrm{~J}}$ : variância da interação entre tratamentos e anos;

$\hat{\sigma}_{\overline{\mathrm{F}}}^{2}=\hat{\sigma}_{\mathrm{T}}^{2}+\frac{\hat{\sigma}_{\mathrm{TA}}^{2}}{\mathrm{~L}}+\frac{\hat{\sigma}^{2}}{\mathrm{JL}}=\frac{\mathrm{Q}_{3}}{\mathrm{JL}}$ : variância fenotípica entre médias de tratamentos.

\subsubsection{Covariâncias genéticas e fenotípicas}

Côv $=\mathrm{P}_{1}$ : covariância do erro experimental entre parcelas;

Côv $\mathrm{T}_{\mathrm{T}}=\frac{\mathrm{P}_{3}-\mathrm{P}_{2}}{\mathrm{JL}}$ : covariância genética entre tratamentos (linhagens), que corresponde à covariância genética aditiva;

Côv $\mathrm{TA}_{\mathrm{TA}}=\frac{\mathrm{P}_{2}-\mathrm{P}_{1}}{\mathrm{~J}}$ : covariância da interação entre tratamentos e anos; 
Côv $_{\overline{\mathrm{F}}}=\operatorname{Côv}_{\mathrm{T}}+\frac{\text { Côv }_{\mathrm{TA}}}{\mathrm{J}}+\frac{\text { Côv }}{\mathrm{JL}}=\frac{\mathrm{P}_{3}}{\mathrm{JL}}$ : covariância fenotípica entre médias de tratamentos.

\subsubsection{Correlações genéticas e fenotípicas entre os caracteres}

As correlações genéticas e fenotípicas entre os caracteres foram estimadas de acordo com o procedimento relatado por Falconer \& Mackay (1996) e Kempthorne (1966), ou seja:

$$
\begin{aligned}
& r_{A(X, Y)}=\frac{\operatorname{Côv}_{T(X, Y)}}{\hat{\sigma}_{T(X)} \hat{\sigma}_{T(Y)}}: \text { correlação genética aditiva entre os caracteres } X \text { e } Y ; \\
& r_{\bar{F}(X, Y)}=\frac{\operatorname{Côv}_{\bar{F}(X, Y)}}{\hat{\sigma}_{\bar{F}(X)} \hat{\sigma}_{\bar{F}(Y)}}: \text { correlação fenotípica entre os caracteres } X \text { e } Y
\end{aligned}
$$

\subsubsection{Coeficientes de herdabilidade}

$\hat{h}_{\overline{\mathrm{x}}}^{2}=\frac{\hat{\sigma}_{\mathrm{T}}^{2}}{\hat{\sigma}_{\overline{\mathrm{F}}}^{2}}:$ herdabilidade (sentido restrito) entre médias de tratamentos.

\subsubsection{Coeficientes de variação experimental e genético}

$$
\begin{aligned}
& C V_{e}=\left(\frac{\sqrt{\hat{\sigma}^{2}}}{\bar{X}}\right) 100: \text { coeficiente de variação experimental; e } \\
& C V_{g}=\left(\frac{\sqrt{\hat{\sigma}_{T}^{2}}}{\bar{X}}\right) 100: \text { coeficiente de variação genético. }
\end{aligned}
$$




\subsubsection{Ganho esperado com seleção}

Os ganhos esperados com seleção foram calculados a partir do procedimento descrito por Vencovsky \& Barriga (1992), ou seja:

$$
\mathrm{Gs}=\mathrm{ds} \frac{\hat{\sigma}_{\mathrm{A}}^{2}}{\hat{\sigma}_{\overline{\mathrm{F}}}^{2}} \text {, onde: }
$$

Gs : ganho esperado com seleção;

ds : diferencial de seleção, com intensidade de seleção de 20\%;

$\hat{\sigma}_{\mathrm{A}}^{2}$ : variância genética aditiva, que corresponde à variância genética entre tratamentos $\left(\hat{\sigma}_{\mathrm{T}}^{2}\right)$;

$\hat{\sigma}_{\overline{\mathrm{F}}}^{2}$ : variância fenotípica entre médias de tratamentos: $\hat{\sigma}_{\overline{\mathrm{F}}}^{2}=\hat{\sigma}_{\mathrm{T}}^{2}+\frac{\hat{\sigma}_{\mathrm{TA}}^{2}}{\mathrm{~L}}+\frac{\hat{\sigma}^{2}}{\mathrm{JL}}=\frac{\mathrm{Q}_{3}}{\mathrm{JL}}$

As estimativas das variâncias genéticas aditivas $\left(\hat{\sigma}_{A}^{2}\right)$ e das variâncias fenotípicas entre médias de tratamentos $\left(\hat{\sigma}_{\bar{F}}^{2}\right)$, para cada ano de experimentação e para as análises conjuntas de dois, três e quatro anos, são diferentes, pois para cada caso considerou-se a estimativa correspondente ao ano ou à combinação de anos para a estimação do ganho esperado com seleção.

\subsubsection{Estimação dos erros associados às estimativas dos parâmetros genéticos e fenotípicos}

As estimativas dos desvios-padrão e intervalos de confiança associados às estimativas dos parâmetros genéticos e fenotípicos foram obtidas de acordo com os processos relatados por Snedecor \& Cochran (1980), Knapp et al. (1985) e Barbin (1993). 


\subsubsection{Intervalo de confiança associado à estimativa da variância do erro experimental}

$$
\begin{aligned}
& \mathrm{IC}=\mathrm{P}\left[\frac{\mathrm{f} \sigma^{2}}{\chi_{\mathrm{f} ; 0,975}^{2}} \leq \sigma^{2} \leq \frac{f \sigma^{2}}{\chi_{\mathrm{f} ; 0,025}^{2}}\right]=0,95, \text { onde: } \\
& \mathrm{IC}=\text { Intervalo de confiança; } \\
& \mathrm{f}=\text { número de graus de liberdade associado ao erro experimental; } \\
& \sigma^{2}=\text { variância do erro experimental; e } \\
& \chi^{2}=\text { qui-quadrado tabelado. }
\end{aligned}
$$

\subsubsection{Intervalo de confiança associado à estimativa da variância genética de linhagens}

$\mathrm{IC}=\mathrm{P}\left[\frac{\mathrm{nt} \sigma_{\mathrm{T}}^{2}}{\chi_{\mathrm{nt} ; 0,975}^{2}} \leq \sigma_{\mathrm{L}}^{2} \leq \frac{\mathrm{nt} \sigma_{\mathrm{T}}^{2}}{\chi_{\mathrm{nt} ; 0,025}^{2}}\right]=0,95$, onde:

IC = Intervalo de confiança;

$\mathrm{nt}=$ número de graus de liberdade associado à estimativa da variância genética de tratamentos (linhagens);

$\sigma_{\mathrm{T}}^{2}=$ variância genética de tratamentos (linhagens); e

$\chi^{2}=$ qui-quadrado tabelado.

O valor de nt foi obtido através do método de Satterthwaite, empregado para calcular o número de graus de liberdade associado a uma estimativa de variância obtida da combinação linear de dois quadrados médios, referentes a duas fontes de variação, com números de graus de liberdade conhecidos (Barbin, 1993): 
$\mathrm{nt}=\frac{\left(\mathrm{QM}_{\mathrm{T}}-\mathrm{QM}_{\mathrm{TA}}\right)^{2}}{\frac{\mathrm{QM}_{\mathrm{T}}^{2}}{\mathrm{f}_{1}}+\frac{\mathrm{QM}_{\mathrm{TA}}^{2}}{\mathrm{f}_{2}}}$, onde:

$\mathrm{QM}_{\mathrm{T}}=$ quadrado médio de tratamentos (linhagens);

$\mathrm{QM}_{\mathrm{TA}}=$ quadrado médio da interação entre tratamentos e anos;

$\mathrm{f}_{1}=$ número de graus de liberdade de tratamentos; e

$\mathrm{f}_{2}=$ número de graus de liberdade da interação entre tratamentos e anos.

\subsubsection{Intervalo de confiança associado à estimativa da variância da interação de linhagens com anos}

IC $=P\left[\frac{n t \sigma_{T A}^{2}}{\chi_{n t ; 0,975}^{2}} \leq \sigma_{T A}^{2} \leq \frac{n t \sigma_{T A}^{2}}{\chi_{n t ; 0,025}^{2}}\right]=0,95$, onde:

IC = Intervalo de confiança;

$\sigma_{\mathrm{TA}}^{2}=$ variância da interação entre tratamentos e anos;

$\chi^{2}=$ qui-quadrado tabelado; e

$\mathrm{nt}=$ número de graus de liberdade associado à estimativa da variância da interação entre tratamentos e anos, de acordo com Barbin (1993):

$\mathrm{nt}=\frac{\left(\mathrm{QM}_{\mathrm{TA}}-\mathrm{QM}_{\mathrm{E}}\right)^{2}}{\frac{\mathrm{QM}_{\mathrm{TA}}^{2}}{\mathrm{f}_{1}}+\frac{\mathrm{QM}_{\mathrm{E}}^{2}}{\mathrm{f}_{2}}}$, onde:

$\mathrm{QM}_{\mathrm{TA}}=$ quadrado médio da interação entre tratamentos e anos;

$\mathrm{QM}_{\mathrm{E}}=$ quadrado médio do erro experimental;

$\mathrm{f}_{1}=$ número de graus de liberdade da interação entre tratamentos e anos; e

$\mathrm{f}_{2}=$ número de graus de liberdade associado ao erro experimental. 
3.3.5.4 Intervalo de confiança associado à estimativa do coeficiente de herdabilidade na análise conjunta

$$
\begin{aligned}
& \text { IC }=P\left\{\left\{1-\left[\left(\frac{Q_{3}}{Q_{2}} F_{0,975: f_{3}, f_{2}}\right]^{-1}\right\} \leq h_{\bar{x}}^{2} \leq\left\{1-\left[\left(\frac{Q_{3}}{Q_{2}} F_{0,025: f_{3}, f_{2}}\right]^{-1}\right\}\right\}=0,95\right.\right. \\
& I C=\text { Intervalo de confiança; } \\
& \mathrm{Q}_{3}=\text { quadrado médio do efeito de tratamentos (linhagens); } \\
& \mathrm{Q}_{2}=\text { quadrado médio do efeito da interação entre tratamentos e anos; } \\
& \mathrm{f}_{3}=\text { número de graus de liberdade associado à tratamentos; e } \\
& \mathrm{f}_{2}=\text { número de graus de liberdade associado à interação entre tratamentos e anos. }
\end{aligned}
$$




\section{RESULTADOS E DISCUSSÃO}

$\mathrm{Na}$ Tabela 1 estão apresentadas as médias das linhagens e os seus respectivos intervalos de variação para os caracteres altura da planta na maturação (AM), acamamento (AC), número de dias para maturação (DM) e produção de grãos (PG), em cada um dos anos de experimentação e na média dos quatro anos. Nota-se que, para o caráter $A M$, as médias não apresentam praticamente nenhuma variação ao longo dos anos. Para o caráter AC, observa-se que, em média, as linhagens apresentaram um acamamento baixo. Nos anos agrícolas de 1995/96 e de 1996/97, a menor nota é zero, devido a um erro cometido na avaliação de campo. As notas para este caráter deveriam variar de 1 a 5 , mas foi utilizado o valor zero como a menor nota da escala nestes anos. Para o caráter DM, observa-se que nos dois primeiros anos de experimentação as médias foram mais baixas que nos outros dois. Isso pode ser explicado pela época de plantio diferente $(27 / 11,06 / 12,10 / 11$ e 11/11, para os anos 1995/96, 1996/97, 1998/99 e 1999/00, respectivamente), pois, como se sabe, a soja é muito influenciada pela época de plantio. O plantio feito no princípio do mês de novembro permitiu a melhor discriminação dos materiais, sendo possível agrupar as linhagens em precoces e tardias. Para a produção de grãos ( $P G$ ), observa-se uma maior variação ao longo dos quatro anos de experimentação, sendo isto devido à grande influência do ambiente sobre o caráter. Nota-se, para o ano de 1998/99, que a média de PG destaca-se das demais, podendo este fato ser atribuído ao efeito do ano.

$\mathrm{Na}$ Tabela 2, tem-se as médias das testemunhas para os quatro caracteres, em cada um dos anos de experimentação e na média dos quatro anos. Comparando-se esta tabela com a anterior, algumas considerações podem ser feitas: os caracteres AM e AC, em geral, tem suas médias de linhagens semelhantes às médias das testemunhas; para o caráter DM, observa-se que as médias das linhagens foram semelhantes à das testemunhas nos dois primeiros anos de experimentação, enquanto que, para os dois últimos anos, as testemunhas apresentaram médias inferiores à das linhagens, mostrando que há um número considerável de linhagens com dias para maturação maior do que o das testemunhas; no que diz respeito ao caráter $P G$, a 
média das linhagens foi inferior às médias das testemunhas nos quatro anos e também na conjunta, entretanto, existem linhagens com média acima da média de qualquer uma das testemunhas, o que pode ser constatado observando-se o maior valor do intervalo na análise conjunta (370,6 g/parcela). Tem-se ainda nesta tabela a cultivar IAC-Foscarin-31 como sendo em média a mais produtiva (367,5 g/parcela) entre as testemunhas, seguida pela IAC-12 (327,3 g/parcela) e IAS-5 (297,1 g/parcela). Com relação a AM, a testemunha mais produtiva apresenta a maior altura de plantas, enquanto que a com menor produção apresenta a menor altura, na média dos quatro anos de experimentação. Para os caracteres AC e DM, as testemunhas IAC-12 e IAS-5 apresentam magnitude semelhante. A IAC-Foscarin-31, por sua vez, é mais alta (119,3 cm/planta) e apresenta média de acamamento superior às médias daquelas duas.

As análises de variância individuais e conjunta estão apresentadas nas Tabelas 3 e 4, respectivamente, para linhagens e para os quatro caracteres. Observa-se que a fonte de variação Linhagens foi altamente significativa em todos os casos, mostrando que existem linhagens com diferenças significativas, sendo possível a seleção de material superior. $\mathrm{Na}$ análise conjunta, observa-se que a fonte de variação da interação $(L \times A)$ foi também altamente significativa, mostrando que a interação entre genótipo e anos esteve presente, o que provoca uma inconsistência na classificação das linhagens ao longo dos anos, o que será discutido mais adiante.

$\mathrm{Na}$ Tabela 5, estão apresentadas as estimativas dos coeficientes de variação experimental (CVe\%) em cada um dos anos de experimentação e nas análises conjuntas para os caracteres AM, AC, DM e PG. O caráter AM apresentou coeficientes de variação experimental baixos, praticamente constante ao longo dos anos de experimentação, assim como as respectivas médias. O caráter $\mathrm{AC}$, apresenta $\mathrm{CVe} \%$ não muito elevados. Neste caso, os valores apresentados são baseados nas análises com os dados transformados. Para o caráter DM, os $C V e \%$ foram muito baixos, enquanto que para o caráter $P G$, observa-se um $C V$ \% mais elevado, por ser um caráter bastante influenciado pelo ambiente. Observa-se que no ano agrícola de 1999/00 o CVe\% foi o mais elevado, mas isso é justificado pela média baixa naquele ano, assim como ocorreu em 1995/96. Assim, devemos observar também a média dos tratamentos e não se ater somente aos valores dos coeficientes de variação experimental para concluir se temos ou não uma boa precisão experimental. 
As estimativas de CVe obtidas nos quatros anos de experimentação concordam com as estimativas encontradas por outros autores que desenvolveram trabalhos na mesma área experimental. Prado (1999), utilizando quatro populações de soja, oriundas de cruzamentos biparentais e conduzidas pelo método SSD, e parcelas experimentais semelhantes às desse trabalho, encontrou CVe variando de 6,12\% a 10,64\% para AM e de 20,19\% a 30,34\% para PG; portanto, de magnitude semelhante às do presente trabalho. Laínez-Mejía (1996), utilizando também parcelas experimentais semelhantes, encontrou para o caráter AM CVe variando de $15,1 \%$ a $17,7 \%$, para DM variando de $1,6 \%$ a $7,3 \%$, e para $\mathrm{PG}$, de $18,6 \%$ a $35,2 \%$. Contudo, os experimentos foram realizados em outras áreas experimentais dentro do município de Piracicaba.

Outros autores que desenvolveram seus trabalhos no Departamento de Genética da Escola Superior de Agricultura "Luiz de Queiroz" da Universidade de São Paulo também encontraram CVe de mesma magnitude, mesmo utilizando parcelas experimentais diferentes. Prado (1994), avaliando quatro cruzamentos biparentais de soja em gerações avançadas, visando a seleção de genótipos superiores para teor de proteína e produção de grãos simultaneamente, e utilizando parcelas experimentais constituídas por fileiras de 1,0 m de comprimento espaçadas de $0,50 \mathrm{~m}$, encontrou CVe variando de $9,08 \%$ a $12,29 \%$ para $A M$, de $10,91 \%$ a $12,78 \%$ para AC, de 2,03\% a 2,29\% para DM, e de 28,55\% a 37,60\% para PG. Por outro lado, Gieco (1997), utilizando progênies provenientes de cruzamentos biparentais de soja e parcelas semelhantes às de Prado (1994), encontrou CVe para produção variando de 14,31\% a 23,22\% nas análises individuais e de $16,99 \%$ a $19,69 \%$ nas análises conjuntas.

Pulcinelli (1997), utilizando populações oriundas de vários cruzamentos, dentre elas a população que é usada neste trabalho, e parcelas experimentais de 1,0 m x 1,0 m, obteve para AM um CVe variando de $10,20 \%$ a $15,66 \%$ nos quatro anos de experimentação, com as variâncias dos erros experimentais de magnitude semelhante e médias menores do que as encontradas nesse trabalho. Para o caráter PG, obteve CVe variando de $21,81 \%$ a $40,81 \%$. Unêda-Trevisoli (1999), estudando progênies obtidas por cruzamentos óctuplos em soja e utilizando parcelas experimentais bem maiores (duas fileiras de 5,0 m de comprimento e espaçadas de $0,50 \mathrm{~m}$ entre si), observou CVe variando de $8,63 \%$ a $14,94 \%$ para $\mathrm{AM}$, de $7,95 \%$ a $13,62 \%$ para AC, de $0,63 \% \%$ a $2,00 \%$ para $D M$, e de $18,00 \%$ a $24,67 \%$ para $P G$.

As estimativas das variâncias genéticas aditivas entre linhagens $\left(\hat{\sigma}_{L}^{2}\right)$ e do erro experimental entre parcelas $\left(\hat{\sigma}^{2}\right)$, com seus respectivos intervalos de confiança, obtidas das análises de 
variância individuais, podem ser observadas na Tabela 6. Para o caráter DM, a variância de linhagens foi bem maior para os dois últimos anos de avaliação, e isto se deve ao fato de que nestes dois anos pôde-se discriminar melhor os materiais para este caráter, devido ao plantio mais cedo. Isto também pode ser observado para o caráter AM. Para PG, o maior valor observado para variância de linhagens foi no ano agrícola de 1998/99, e este fato pode ser atribuído à maior discriminação que ocorreu entre os diferentes genótipos, nesse ano.

$\mathrm{Na}$ Tabela 7, estão apresentadas as estimativas das variâncias genéticas aditivas entre linhagens $\left(\hat{\sigma}_{L}^{2}\right)$, da interação entre linhagens e anos $\left(\hat{\sigma}_{L A}^{2}\right)$ e do erro experimental entre parcelas $\left(\hat{\sigma}^{2}\right)$, com seus respectivos intervalos de confiança, obtidas das análises de variância conjuntas. Nesta, observa-se que para os caracteres AM e AC a magnitude da estimativa da variância da interação é menor que a da variância genética entre linhagens, ao contrário dos outros dois caracteres, onde as duas variâncias apresentaram magnitude semelhante. Isto indica que os caracteres DM e PG são mais influenciados pelas oscilações decorrentes das interações com anos do que os outros dois caracteres e, consequentemente, são mais complexos para o melhoramento.

Analisando-se as Tabelas 6 e 7 em conjunto, observa-se a influência da interação genótipo $x$ anos nas estimativas das variâncias genéticas aditivas entre linhagens. Se não ocorresse interação, esperar-se-ia que as estimativas variassem menos ao longo dos quatro anos de experimentação. No caso do caráter AM, por exemplo, as estimativas individuais deveriam ser em média 213,1 , estimativa obtida na análise conjunta, livre da interação, visto que existe a relação $\sigma_{\mathrm{L}}^{2}+\sigma_{\mathrm{LA}}^{2}=\frac{1}{4}\left(\sigma_{\mathrm{L} 1}^{2}+\sigma_{\mathrm{L} 2}^{2}+\sigma_{\mathrm{L} 3}^{2}+\sigma_{\mathrm{L} 4}^{2}\right)$, de acordo com Vencovsky \& Barriga (1992), onde $\sigma_{\mathrm{L}}^{2}$ é a variância aditiva entre linhagens obtida na análise conjunta. No entanto, no ano agrícola de 1999/00 obteve-se uma estimativa de 374,7, valor este muito discrepante do estimado no ano 1995/96 (136,2). Na Tabela 7, ainda para o caráter AM, nota-se que a estimativa da variância da interação representa $19,4 \%$ do valor da variância entre linhagens. Observando o comportamento da variância de linhagens ao longo dos quatro anos (Tabela 6), nota-se que ocorrem incrementos de ano para ano (50,1\%; 40,1\% e 30,9\%, respectivamente). O mesmo ocorre para AC. Tomando-se o caráter DM, cuja estimativa da variância da interação entre linhagens e anos representa $73,5 \%$ da estimativa da variância de linhagens na análise conjunta, e observando-se o comportamento das estimativas para linhagens ao longo dos anos de experimentação, nota-se que não se assemelha aos dois casos anteriores. Do ano agrícola 1995/96 para 1996/97, ocorre um decréscimo no valor da estimativa da variância de linhagens 
(-28,7\%), seguido de aumento $(+837,5 \%)$ e, novamente, decréscimo $(-19,2 \%)$. Para o caráter PG, onde a estimativa da variância da interação é de $91,4 \%$ da variância de linhagens, um comportamento semelhante é observado. Ao longo dos anos, ocorre decréscimo $(-58,7 \%)$, acréscimo $(+602,2 \%)$ e novamente decréscimo $(-55,4 \%)$, nas estimativas da variância de linhagens. Isto indica que quanto maior a variância da interação linhagens $x$ anos, mais irregular será o comportamento das variâncias de linhagens nos diferentes anos.

Na Tabela 8, estão apresentadas as estimativas dos coeficientes de herdabilidade no sentido restrito entre médias de linhagens $\left(h_{\overline{\mathrm{x}}}^{2} \%\right)$ e seus respectivos intervalos de confiança, em cada um dos anos de experimentação e nas análises conjuntas. Numa visão geral, observa-se estimativas de herdabilidade elevadas para os quatro caracteres. Entretanto, para PG estes valores são surpreendentes à primeira vista, por ser um caráter considerado de baixa herdabilidade. As estimativas encontradas podem ser justificadas por se tratar de uma população em geração avançada de endogamia $\left(F_{7}\right)$, o que acarreta um aumento considerável da variância genética aditiva, devido à maior discriminação entre os genótipos. A estimativa do coeficiente de herdabilidade para AM é superior a de todos os outros caracteres, indicando que este é o caráter menos influenciado pelo ambiente. No outro extremo, a herdabilidade menor de $P G$ reflete um caso diferente do anterior, sendo este o mais influenciado pelo ambiente, fato já bastante conhecido.

Outros autores encontraram resultados semelhantes para herdabilidade. Para o caráter AM, observa-se que as estimativas são de mesma magnitude às encontradas por Mauro et al. (1995), Santos et al. (1995), Taware et al. (1997) e Reis (2000) e ligeiramente superiores às encontradas por Azevedo Filho et al. (1998) e Mauro et al. (2000). Tratando-se do caráter DM, as estimativas encontradas para a herdabilidade no sentido restrito concordam com Santos et al. (1995), Taware et al. (1995), Taware et al. (1997), Azevedo Filho et al. (1998) e Reis (2000). Azevedo Filho et al. (1998) observaram ainda estimativas de menor magnitude para este caráter sob condições de alta saturação de alumínio. Considerando o caráter PG, as estimativas de herdabilidade são de magnitude semelhantes às observadas por Taware et al. (1995). Entretanto, foram superiores às estimativas encontradas por Srivastava \& Jain (1994), Santos et al. (1995), Azevedo Filho et al. (1998), Spehar (1999), Mauro et al. (2000) e Toledo et al. (2000). As estimativas de herdabilidade observadas por Azevedo (2000) e Backes (2000) apresentaram uma faixa de variação que vai desde estimativas menores às encontradas neste trabalho até estimativas de mesma magnitude para os caracteres AM e DM. Azevedo (2000) e Reis (2000) obtiveram estimativas de herdabilidade para o caráter PG também com ampla 
variação. A magnitude da estimativa do coeficiente de herdabilidade no sentido restrito varia de acordo com a precisão experimental e a população utilizada. A precisão experimental reflete a variância do resíduo, ou erro experimental, e a média populacional. A variância do resíduo influencia de forma inversa a herdabilidade, ou seja, quanto menor o seu valor, maior é a herdabilidade. A população utilizada refletirá na magnitude da variação genética e influencia de forma direta a herdabilidade. Desse modo, a ocorrência de valores diferentes de herdabilidade entre diferentes populações é esperada (Vencovsky, 1970; Pesek \& Baker, 1971; Ramalho et al., 1993).

O coeficiente de herdabilidade per se não reflete necessariamente a quantidade de variação existente na população e, consequentemente, o ganho esperado com seleção. A predição deste depende ainda da amplitude de variação que afeta o diferencial de seleção. Burton (1952), citado por Geraldi (1977), sugere que seja utilizado o coeficiente de variação genético (CVg\%) juntamente com a herdabilidade para comparação da variabilidade genética de diferentes populações e diferentes caracteres, bem como para se ter uma idéia do ganho esperado com seleção, uma vez que este é uma função do coeficiente de variação genético, coeficiente de herdabilidade e diferencial de seleção. Assim, na Tabela 9 são apresentadas as estimativas dos coeficientes de variação genético ( $\mathrm{CVg} \%)$ em cada um dos anos de experimentação e nas análises conjuntas.

Na tabela 9, observa-se que o caráter DM apresenta estimativas de CVg muito menores do que os outros três caracteres. Analisando-se esta informação juntamente com os coeficientes de variação experimental (Tabela 5) e de herdabilidade (Tabela 8), observa-se que este caráter apresenta CVg muito baixo, CVe também muito baixo e alta herdabilidade, indicando que este caráter é muito pouco influenciado pelo ambiente. Os altos coeficientes de herdabilidade observados para $A C, A M$ e $P G$, são mérito da variabilidade genética para estes caracteres existente na população estudada. Outros autores encontraram valores de $\mathrm{CVg}$ de mesma magnitude, como Prado (1999), com estimativas variando de $8,75 \%$ a $32,73 \%$ para PG e de $6,21 \%$ a $29,80 \%$ para AM, e Pulcinelli (1997), com estimativas variando de $7,13 \%$ a $8,91 \%$ para AM e de $20,47 \%$ a $36,16 \%$ para $P G$, em diferentes populações.

Ainda na Tabela 9, para o caráter AM, observa-se que os $\mathrm{CVg}$ variam de ano para ano, de 13,39\% a 22,25\%, acompanhando as variâncias genéticas aditivas ( $\left.\hat{\sigma}_{\mathrm{L}}^{2}\right)$ para cada ano (Tabela 6). As médias para este caráter (Tabela 1) ao longo dos quatro anos de experimentação são de mesma magnitude, não sendo a causa da variação do CVg. A interação entre genótipos e anos 
é o fator responsável pela variação observada nas estimativas das variâncias de linhagens, podendo levar à sub ou superestimação do $\mathrm{CVg}$, quando analisado individualmente em cada ano. $\mathrm{Na}$ análise conjunta, observa-se um $\mathrm{CVg}$ de 16,72\%, uma estimativa intermediária, livre dos efeitos da interação. Resultados semelhantes podem ser observados também para os demais caracteres estudados, com algumas particularidades. Para AC, as médias e variâncias de linhagens variam para cada ano, refletindo na variação do seu $\mathrm{CVg}$, sendo isso observado também para os caracteres DM e PG. No caso de DM, o CVg variou de 2,05\% a 5,08\%, sendo estas estimativas correspondentes aos anos que apresentaram a menor e a maior variância genética aditiva entre linhagens (6,05 e 56,72, respectivamente). Observa-se CVg de magnitude semelhante para os anos agrícolas de 1995/96 e 1996/97, justamente aqueles em que não foi possível a discriminação das linhagens no que se refere a este caráter. Também pode ser observado para os anos agrícolas de 1998/99 e 1999/00 magnitude semelhante, porém, neste caso é possível a discriminação dos materiais devido ao maior $\mathrm{CVg}$ nestes dois anos. Analisando-se o caráter PG, observa-se que o CVg variou de 14,06\% a 29,55\%. Observando-se as estimativas das variâncias genéticas aditivas (Tabelas 6 e 7) e as médias para cada ano (Tabela 1), pode-se entender o que ocorre com este caráter. A menor estimativa do CVg é função da média da população naquele ano agrícola e da menor estimativa da variância de linhagens, subestimada devido à influência dos efeitos da interação com anos. A maior estimativa do $\mathrm{CVg}$ foi função da combinação da média populacional com a estimativa da variância genética naquele ano. Analisando-se a razão entre o maior e menor $\mathrm{CVg}$ para os quatro caracteres, nota-se que para $A M$ e AC esta razão é de magnitude semelhante $(1,7$ e 1,6, respectivamente), enquanto que para DM e PG esta razão é maior (2,5 e 2,1, respectivamente). Esta diferença reflete novamente a influência da interação sobre cada caráter. Assim, os caracteres mais influenciados pelos efeitos da interação com anos apresentam razão maior do que os caracteres menos influenciados.

$\mathrm{Na}$ Tabela 10, estão apresentadas as estimativas das covariâncias genéticas aditivas $\left(\operatorname{Cov}_{\mathrm{A}}\right)$ e fenotípicas entre médias de linhagens $\left(\operatorname{Cov}_{\bar{F}}\right)$, em cada um dos anos de experimentação e nas análises conjuntas, entre os caracteres AM, AC, DM e PG. Nota-se estimativas positivas e negativas, que irão refletir no sentido (positivo ou negativo) nas correlações genéticas e fenotípicas.

$\mathrm{Na}$ Tabela 11, estão apresentadas as estimativas das correlações genéticas aditivas $\left(\mathrm{r}_{\mathrm{A}(\mathrm{X}, \mathrm{Y})}\right)$ e fenotípicas entre médias de linhagens $\left(r_{\bar{F}(X, Y)}\right)$, entre os caracteres $A M, A C, D M$ e $P G$, obtidas 
a partir das análises individuais e conjuntas dos quatro anos de experimentação. Observa-se que, em geral, as estimativas das correlações genéticas apresentaram magnitude ligeiramente superior às fenotípicas, com exceção da correlação entre AM e PG para o ano agrícola de 1995/96. Sendo a correlação genética entre dois caracteres de mesma magnitude que a correlação fenotípica, têm-se coincidência entre o que é observado fenotipicamente e o que está ocorrendo geneticamente. Diversos autores observaram que, geralmente, as correlações genéticas são superiores às fenotípicas, como Monteverde (1984), citado por Marschalek (1995), Santos et al. (1995), Azevedo Filho et al. (1998) e Backes (2000). No entanto, Board et al. (1997) obteve estimativas de correlação genética inferiores às fenotípicas entre caracteres associados à produção de grãos. Analisando-se as correlações entre todos os caracteres para a análise conjunta, observa-se que o caráter AM está melhor correlacionado com AC e DM, do que com PG. $O$ caráter $A C$ apresenta uma baixa correlação com DM e está negativamente correlacionado com PG. Isto significa dizer que, se a seleção for praticada em PG, selecionamos para a redução de $\mathrm{AC}$, o que é desejável em um programa de melhoramento. A causa desta correlação ser negativa pode ser explicada pelo fato de que plantas muito acamadas dificultam a colheita, mesmo que ela seja feita manualmente, e ocasionam perdas de grãos pelo contato das vagens com o solo. DM e PG estão também correlacionados positivamente, o que é esperado. Como as estimativas não apresentam valores absolutos, ou seja, 1 (positivo ou negativo), os indivíduos classificados como melhores ou piores para um caráter não necessariamente o serão para outro, havendo então, possibilidade de seleção de genótipos com atributos favoráveis para os dois caracteres. Nota-se, ainda, que a seleção para maior PG somente implica na seleção de indivíduos com maior AM e DM, o que não é desejável no melhoramento de soja.

Ainda na Tabela 11, pode-se perceber a influência da interação genótipo x ambiente nas estimativas das correlações. Analisando-se as correlações genéticas e fenotípicas em conjunto, observa-se que as correlações entre os caracteres apresentam considerável variação de um ano agrícola para outro, principalmente aqueles envolvendo DM e PG, justamente os dois caracteres mais influenciados pela interação. As correlações genéticas entre AM e PG, por exemplo, apresentam os valores $+0,038$; $-0,417$; $+0,457$ e $+0,444$, para os anos $1995 / 96$, 1997/98, 1998/99 e 1999/00, respectivamente; enquanto que na análise conjunta este valor foi de $+0,280$. Santos et al. (1995) e Backes (2000) encontraram estimativas de correlação entre estes dois caracteres, tanto genética quanto fenotípica, de magnitude semelhante. Situação semelhante pode ser observada para as correlações entre AC e DM e entre DM e PG. Santos et al. (1995), Taware et al. (1995), Azevedo Filho et al. (1998) e Backes (2000), observaram 
estimativas de magnitude semelhante às encontradas entre os caracteres $\mathrm{AM}$ e DM, e entre DM e PG. Analisando-se a correlação genética entre AM e PG, nota-se a importância da estimação dos parâmetros genéticos em mais de um ano de experimentação. Supondo-se a seleção de indivíduos no ano agrícola 1996/97, no qual a estimativa do coeficiente de correlação genético entre $A M$ e PG foi de -0,417, considerar-se-ia, de forma geral, que as linhagens mais produtivas seriam as que apresentaram menor altura de planta. Entretanto, a estimativa baseada em quatro anos, mostra que a correlação entre os caracteres para esta população é positiva e de magnitude baixa $(+0,280)$, indicando que estes dois caracteres são positivamente correlacionados e, assim, é preciso cuidado na seleção das plantas mais produtivas, pois isso pode levar a um aumento de AM e, consequentemente, de AC.

$\mathrm{Na}$ Tabela 12 encontram-se as estimativas das médias da população $\left(\bar{X}_{p}\right)$, das linhagens selecionadas $\left(\bar{X}_{s}\right)$, das testemunhas $\left(\bar{X}_{t}\right)$, da herdabilidade entre médias de linhagens $\left(h_{\bar{X}}\right)$, dos ganhos esperados com seleção (Gs), dos ganhos esperados com seleção em percentual da população original $\left(G s_{p} \%\right)$ e dos ganhos esperados com seleção em percentual das testemunhas $\left(\mathrm{Gs}_{\mathrm{t}} \%\right)$, para os caracteres $\mathrm{AM}$ e $\mathrm{PG}$ apenas, representativos de caracteres com baixa e alta influência da interação, respectivamente. Para ambos considerou-se seleção com intensidade de $20 \%$, para a obtenção das estimativas dos ganhos esperados com seleção. Com relação aos ganhos esperados com seleção para AM, em porcentagem da população original, chama a atenção o fato das estimativas dos ganhos serem maiores para os anos 3 e 4 individualmente (32,06 e 37,74 cm/planta, respectivamente) do que nas análises conjuntas considerando dois, três e quatro anos (23,26; 24,27 e $27,00 \mathrm{~cm} /$ planta, respectivamente). Isto pode levar a uma conclusão errônea de que é preferível que se aplique a seleção com base em anos individuais, do que baseá-la na média de mais de um ano. Porém, não se deve esquecer da presença da interação entre genótipos e anos existente na estimativa de $\sigma_{\mathrm{L}}^{2}$ e, consequentemente, no ganho esperado com seleção, quando se utiliza apenas um ano de experimentação. A utilização de mais de um ano possibilita maior segurança de que os melhores genótipos estão sendo selecionados, pois permite que se isole a fonte de variação interação, obtendo-se estimativas mais reais para variância de linhagens e, consequentemente, para o ganho com seleção. Isto também propicia a obtenção de estimativas mais reais para a herdabilidade. Nota-se um ganho considerável em relação à média das testemunhas em todos os casos. 
Para o caráter PG, observa-se que a média da população selecionada $(20 \%)$ foi superior às médias das testemunhas em todos os casos apresentados, assim como ocorreu para o caráter $\mathrm{AM}$, mostrando que existem linhagens com média de $\mathrm{PG}$ superior à média das testemunhas. Nota-se que a estimativa de herdabilidade para o conjunto de quatro anos $(72,2 \%)$ foi maior do que as estimativas para dois e três anos (61,6\% e 55,4\%, respectivamente). Como foi observado para AM, também para PG observa-se que os ganhos esperados com a seleção para alguns dos anos, considerados individualmente, foram superiores aos baseados em mais de um ano e, da mesma forma, podem induzir a erros na seleção dos melhores materiais. Quando esta estimativa é baseada em quatro anos (22,12\%), esta é maior do que para dois ou para três anos (19,42\% e 16,35\%, respectivamente), o que é conseqüência da grande interação entre genótipos e anos. Nota-se também um ganho considerável em relação à média das testemunhas, em todos os casos.

A interação genótipo $x$ ambiente, neste caso linhagem $x$ ano, tem importantes conseqüências no melhoramento genético. Analisando-se o comportamento das estimativas de $\mathrm{Gs}_{\mathrm{p}} \%$ na Tabela 12, observa-se que, considerando os anos de experimentação individualmente, em três anos agrícolas (1995/96, 1998/99 e 1999/00) o ganho foi maior para o caráter PG. Quando são observadas as análises conjuntas para dois, três e quatro anos, o ganho esperado com seleção para o caráter PG é menor do que para AM, reflexo, como já mencionado anteriormente, de ser a produção mais influenciada pela interação com anos do que AM. No entanto, nota-se que o ganho esperado com seleção nas análises conjuntas para dois, três e quatro anos, são menos distantes das individuais para o caráter $A M$ do que para $P G$, o que também é um indicativo de que a produção é mais sujeita à interação com anos. Prado (1999) também observou que a interação entre genótipos e anos foi mais pronunciada para PG do que para AM. Quando se utiliza a média de mais de um ano para seleção, as estimativas de $\sigma_{\mathrm{L}}^{2}$ utilizadas no ganho com seleção são isentas do componente da interação.

Nas tabelas 13, 14, 15 e 16, estão distribuídas as médias de todas as linhagens para os caracteres AM, AC (médias originais, não transformadas), DM e PG, respectivamente, em cada um dos quatro anos de experimentação e considerando-se a seleção em dois, três e quatro anos. Nelas, as linhagens estão ordenadas de acordo com a classificação das médias obtidas na análise conjunta dos quatro anos, e as médias destacadas em negrito representam as $20 \%$ melhores em cada critério. Foi utilizado como critério para a ordenação das médias, para cada caráter, a sua correlação genética com o caráter PG, de forma a sempre propiciar a seleção das linhagens mais produtivas. Sendo assim, o caráter AC foi ordenado em ordem crescente de 
médias, enquanto que os demais em ordem decrescente. A análise de cada uma destas tabelas individualmente e comparativamente, permite uma série de observações importantes.

$\mathrm{Na}$ Tabela 13, para o caráter AM, de forma geral, nota-se que os genótipos selecionados concentram-se na parte superior da tabela e que ocorre uma certa constância na seleção dos melhores genótipos. Tomando-se a linhagem 50, por exemplo, observa-se que ela está classificada entre as cinco melhores em cada ano e como a melhor quando se considera o conjunto de dois, três e quatro anos. Tomando-se os 18 melhores genótipos (20\%) na média de quatro anos para AM e comparando-se com as médias de dois e três anos, observa-se que ocorreram pequenas mudanças na ordem de classificação, sugerindo que, se a seleção para AM fosse feita com base em dois anos apenas, ocorreria $83 \%$ de acerto, enquanto que, se fosse baseada em três anos, este acerto seria de $89 \%$. Isso deve-se ao fato desse caráter ser pouco influenciado pela interação com anos.

Quando se trata do caráter AC (Tabela 14), observa-se grande alteração no conjunto de linhagens selecionadas em cada um dos anos, sendo que, nas análises conjuntas, ocorre maior coincidência. A coincidência é de $89 \%$ com dois anos e de $94 \%$ com três anos. Consultando a Tabela 2, que traz as médias das testemunhas para os quatro caracteres estudados, observase que as linhagens selecionadas apresentam médias de acamamento tão boas quanto ao das testemunhas, sendo, portanto, linhagens que praticamente não acamam, característica desejável em soja. Nota-se que a maior parte das linhagens apresentam baixo acamamento, sendo que todas as linhagens que fazem parte do grupo das $20 \%$ melhores possuem média para este caráter inferior à média de qualquer uma das testemunhas (Tabela 2). No final desta tabela são encontradas as linhagens que apresentam acamamento acentuado, como as linhagens $09,02,54,74,66,14,40,36$ e 15, com notas superiores a 3.

Para o caráter DM (Tabela 15), observa-se também grande alteração na classificação das linhagens ao longo dos anos, sendo observada maior coincidência apenas entre as médias de três e quatro anos. Para três anos, observa-se $89 \%$ de coincidência com a população selecionada com base em quatro anos, contra apenas $50 \%$ na baseada em dois anos. Neste caso, não se recomenda fazer seleção com base em informações de dois anos apenas, como poderia ser feito com a caráter AM, o que é conseqüência da maior interação entre genótipos e anos para este caráter. Dentre o material selecionado, todas as linhagens apresentam DM superior à média das testemunhas. 
Na Tabela 16, têm-se as médias para o caráter PG. Diferente de AM, e assim como AC e DM, este caráter apresenta uma inconsistência na ordem de classificação das linhagens. Observase que a seleção baseada em dois anos seria muito menos eficiente ( $44 \%$ de acerto) do que a baseada em três anos (78\% de acerto) de experimentação. Percebe-se nesta tabela claramente a grande influência da interação genótipos $x$ anos sobre este caráter. Tomando-se a linhagem 23, por exemplo, tida como a mais produtiva com base em quatro anos, observa-se que as classificações em cada ano variaram: 36, 4, 6 e 2, respectivamente, nos anos agrícolas de 1995/96, 1996/97, 1998/99 e 1999/00. A linhagem 85 chama a atenção por ser classificada na décima quarta posição no segundo ano e ocupar a sexagésima quinta posição na média de quatro anos. Outros casos como este podem ser observados (linhagens 03, 37, 58 e 89, por exemplo). Não há nenhum caso de uma linhagem estar entre as $20 \%$ selecionadas nos quatro anos considerados individualmente. Nota-se que ocorre uma boa coincidência no grupo selecionado nos dois últimos anos com as médias baseadas em três e quatro anos. Com dois anos apenas é arriscado se aplicar uma seleção de $20 \%$, pois a chance de se manter na população materiais ruins é elevada. Na população selecionada com base em quatro anos, temse 11 linhagens que apresentam média acima da média das testemunhas (330,6 g/parcela). São elas as linhagens 23, 41, 84, 13, 72, 10, 24, 76, 33, 05 e 93, nesta ordem de classificação, sendo que a 23 apresenta média superior à média da melhor testemunha. Observa-se ainda que 26 linhagens possuem média acima da testemunha de menor produção (297,1 g/parcela).

Uma análise comparativa entre os quatro caracteres (Tabelas 13, 14, 15 e 16) nos diferentes anos permite uma série de observações que têm reflexos na seleção de linhagens. Inicialmente, conforme foi mencionado, observa-se que para os caracteres AM e AC existe consistência no comportamento da maioria das linhagens nos diferentes anos, isto é, elas interagem pouco com anos, o que facilita a seleção. O mesmo não é observado para DM e PG, visto que existem comportamentos inconsistentes entre os diferentes anos. Dessa maneira, para estes caracteres é preciso muito cuidado na seleção, não aplicando-se alta intensidade de seleção com base nas médias de linhagens em anos individuais, afim de se evitar o descarte de linhagens promissoras devido à interação com anos.

Uma análise conjunta dos quatro caracteres indica que entre as 18 linhagens promissoras para PG citadas anteriormente, cerca de $50 \%$ apresentam altura média em torno ou abaixo da média das testemunhas. As demais apresentam plantas ligeiramente mais altas, mas não muito distante da testemunha de porte mais alto. Quando avaliadas quanto ao acamamento, das 18 linhagens superiores para produção, cerca de 44\% apresentam média de acamamento superior 
à média das testemunhas, porém, apenas duas (linhagens 41 e 63) possuem médias acima da testemunha que mais acama. Com relação a dias para maturação, todas as linhagens mais produtivas apresentam para este caráter médias superiores à da testemunha mais tardia. Observa-se ainda que algumas das linhagens que escapam da população selecionada (20\%) para o caráter PG são também promissoras, como as linhagens $62,25,16,48,06,86,46,29$, 57 e 38, pois apresentam produção superior a média da testemunha menos produtiva.

Tendo-se dois caracteres, $\mathrm{X}$ e $\mathrm{Y}$, que apresentam correlação genética igual $\mathrm{a}+1$, total coincidência dos genótipos selecionados seria observada tanto em um quanto no outro caráter. No presente trabalho observa-se que as correlações não são absolutas para a população estudada, possibilitando a seleção de linhagens com características próximas a de um tipo ideal. A linhagem 23, por exemplo, apresentou maior produção (371,2 g/parcela), baixo acamamento $(1,107)$, ciclo semi-tardio $(140,4$ dias), estando entre as $20 \%$ selecionadas (18 linhagens) para cada um desses caracteres, e em $19^{\circ}$ lugar para AM (96,7 cm/planta). Um outro exemplo de linhagem promissora é a linhagem 13, que ocupa a quarta classificação para produção (351,4 g/parcela), tem altura de planta $(79,4 \mathrm{~cm})$ de magnitude semelhante a da testemunha mais baixa, apresenta baixo acamamento $(1,229)$ e é de ciclo semi-tardio $(138,9$ dias). Outras linhagens com comportamento semelhante podem ser citadas: 04, 05, 10, 19, $60 \mathrm{e}$ 67.

Pelo exposto, fica claro que o melhorista não deve se basear em um único caráter e nem em dados de apenas um ano de experimentação para selecionar os melhores genótipos ou genótipos promissores, pois é grande a possibilidade de ocorrência de erros na seleção. Dentre os quatro caracteres considerados nesse trabalho, isto é, produção de grãos, dias para maturação, alturas das plantas e acamamento, este problema é mais grave para os dois primeiros. 


\section{CONCLUSÕES}

Os resultados obtidos no presente trabalho permitem apontar as seguintes conclusões:

a) os caracteres produção de grãos e dias para maturação são altamente influenciados pela interação com anos, ao contrário da altura da planta na maturação e acamamento, cuja influência da interação é proporcionalmente bem menor;

b) as estimativas de parâmetros genéticos e fenotípicos (variâncias genéticas e fenotípicas, coeficientes de herdabilidade, correlações genéticas e fenotípicas e ganhos esperados com seleção) envolvendo os caracteres produção de grãos e dias para maturação, obtidas a partir da avaliação experimental em um ano somente, são bastante influenciadas pelos componentes da interação com anos, o que pode acarretar erros na tomada de decisões relacionadas com a seleção de genótipos;

c) recomenda-se que a seleção para os caracteres produção de grãos e dias para maturação seja feita de forma paulatina com o decorrer dos anos, afim de se evitar que genótipos superiores sejam eliminados prematuramente. 
ANEXO: Tabelas 
Tabela 1. Médias e intervalos de variação das linhagens, para os caracteres altura da planta na maturação (AM), acamamento (AC), número de dias para maturação (DM) e produção de grãos (PG), em cada um dos anos de experimentação e na média dos quatro anos.

\begin{tabular}{lcccc}
\hline \multirow{2}{*}{ ANOS } & \multicolumn{4}{c}{ CARÁTER } \\
\cline { 2 - 5 } & $\begin{array}{c}\text { AM } \\
\text { (cm/planta) }\end{array}$ & $\begin{array}{c}\text { AC } \\
\text { (notas: } 1 \text { a } 5)\end{array}$ & $\begin{array}{c}\text { DM } \\
\text { (dias) }\end{array}$ & $\begin{array}{c}\text { PG } \\
\text { (g/parcela) }\end{array}$ \\
\hline \multirow{2}{*}{$1995 / 96$} & 87,2 & 2,17 & 128,3 & 208,6 \\
& $(63,3-125,0)$ & $(1,00-4,67)$ & $(120,0-134,7)$ & $(70,7-435,7)$ \\
$1996 / 97$ & 87,1 & 1,19 & 120,0 & 265,7 \\
& $(60,8-123,5)$ & $(0,00-4,00)$ & $(110,8-124,5)$ & $(156,5-390,0)$ \\
$1998 / 99$ & 87,8 & 1,60 & 148,3 & 342,4 \\
& $(63,7-133,8)$ & $(0,93-4,67)$ & $(130,0-160,8)$ & $(72,4-603,3)$ \\
$1999 / 00$ & 87,0 & 1,63 & 142,9 & 223,7 \\
& $(61,7-135,0)$ & $(1,00-5,00)$ & $(125,0-153,3)$ & $(68,7-384,2)$ \\
Conjunta & 87,3 & 1,61 & 137,5 & 268,1 \\
& $(67,5-127,9)$ & $(0,88-4,29)$ & $(121,6-141,5)$ & $(122,4-370,6)$ \\
\hline
\end{tabular}


Tabela 2. Médias das testemunhas para os caracteres altura da planta na maturação (AM), acamamento $(A C)$, número de dias para maturação $(D M)$ e produção de grãos (PG), em cada um dos anos de experimentação e na média dos quatro anos.

\begin{tabular}{|c|c|c|c|c|c|}
\hline & \multirow[b]{2}{*}{ ANOS } & \multicolumn{4}{|c|}{ CARÁTER } \\
\hline & & $\begin{array}{c}\text { AM } \\
\text { (cm/planta) }\end{array}$ & $\begin{array}{c}\mathrm{AC} \\
\text { (notas: } 1 \text { a } 5 \text { ) }\end{array}$ & $\begin{array}{c}\mathrm{DM} \\
\text { (dias) }\end{array}$ & $\begin{array}{c}P G \\
\text { (g/parcela) }\end{array}$ \\
\hline \multirow{3}{*}{$1995 / 96$} & IAC-12 & 89,6 & 2,24 & 129,4 & 275,7 \\
\hline & IAC-Foscarin-31 & 112,1 & 2,76 & 122,4 & 242,2 \\
\hline & IAS-5 & 75,6 & 1,48 & 120,8 & 253,2 \\
\hline \multirow{3}{*}{$1996 / 97$} & IAC-12 & 84,6 & 1,30 & 122,5 & 320,1 \\
\hline & IAC- Foscarin -31 & 111,9 & 1,40 & 120,4 & 346,2 \\
\hline & IAS-5 & 73,4 & 0,95 & 115,4 & 315,7 \\
\hline \multirow{3}{*}{$1998 / 99$} & IAC-12 & 87,5 & 1,00 & 135,2 & 419,9 \\
\hline & IAC- Foscarin -31 & 126,6 & 2,00 & 131,2 & 480,0 \\
\hline & IAS-5 & 67,2 & 1,00 & 125,0 & 375,9 \\
\hline \multirow{3}{*}{$1999 / 00$} & IAC-12 & 88,8 & 1,00 & 138,1 & 316,1 \\
\hline & IAC- Foscarin -31 & 121,0 & 1,50 & 130,8 & 380,8 \\
\hline & IAS-5 & 69,3 & 1,00 & 125,0 & 279,9 \\
\hline \multirow{3}{*}{ Conjunta } & IAC-12 & 87,3 & 1,33 & 131,5 & 327,3 \\
\hline & IAC- Foscarin -31 & 119,3 & 1,92 & 126,4 & 367,5 \\
\hline & IAS-5 & 70,2 & 1,15 & 121,2 & 297,1 \\
\hline
\end{tabular}


Tabela 3. Análises de variância individuais nos anos agrícolas 1995/96, 1996/97, 1998/99 e 1999/00, para os caracteres altura da planta na maturação (AM), acamamento (AC), número de dias para maturação (DM) e produção de grãos (PG).

\begin{tabular}{|c|c|c|c|c|c|c|c|c|c|c|c|c|c|}
\hline \multirow{2}{*}{ Caráter } & \multirow{2}{*}{ FV } & \multicolumn{3}{|c|}{$1995 / 96$} & \multicolumn{3}{|c|}{$1996 / 97$} & \multicolumn{3}{|c|}{$1998 / 99$} & \multicolumn{3}{|c|}{$1999 / 00$} \\
\hline & & $\mathrm{GL}$ & QM & & $\mathrm{GL}$ & QM & & $\mathrm{GL}$ & QM & & $\mathrm{GL}$ & QM & \\
\hline \multirow{2}{*}{$\mathrm{AM}^{1}$} & Linhagens/C & 84 & 516,81 & ** & 84 & 888,63 & ** & 84 & $1.763,39$ & ** & 84 & $2.300,88$ & ** \\
\hline & Resíduo/C & 160 & 108,78 & & 251 & 71,04 & & 420 & 45,58 & & 420 & 52,50 & \\
\hline \multirow{2}{*}{$A C^{2}$} & Linhagens/C & 84 & 0,1960 & ** & 84 & 0,3276 & ** & 84 & 0,4898 & ** & 84 & 0,5603 & ** \\
\hline & Resíduo/C & 160 & 0,0607 & & 251 & 0,0703 & & 417 & 0,0298 & & 420 & 0,0299 & \\
\hline \multirow{2}{*}{$\mathrm{DM}^{3}$} & Linhagens/C & 84 & 31,537 & $* *$ & 84 & 28,050 & $* *$ & 84 & 354,957 & ** & 84 & 285,165 & ** \\
\hline & Resíduo/C & 160 & 6,055 & & 251 & 3,845 & & 420 & 14,629 & & 420 & 10,128 & \\
\hline \multirow{2}{*}{$P G^{4}$} & Linhagens/C & 84 & $14.233,9$ & $* *$ & 84 & $9.028,5$ & ** & 84 & $68.371,5$ & ** & 84 & $32.689,5$ & ** \\
\hline & Resíduo/C & 159 & $4.103,8$ & & 249 & $3.447,6$ & & 417 & $9.593,1$ & & 411 & $6.473,3$ & \\
\hline
\end{tabular}

** Significativo a $1 \%$ de probabilidade.

${ }^{1} \mathrm{Em} \mathrm{cm} /$ planta.

${ }^{2}$ Notas de 1 a 5; Análise realizada com dados transformados para $\sqrt{x+0,5}$.

${ }^{3}$ Em dias.

${ }^{4}$ Em g/parcela. 
Tabela 4. Análises de variância conjunta dos quatro anos para os caracteres altura da planta na maturação $(A M)$, acamamento $(A C)$, número de dias para maturação (DM) e produção de grãos (PG).

\begin{tabular}{|c|c|c|c|c|c|c|c|c|c|c|c|c|}
\hline \multirow{2}{*}{ FV } & \multicolumn{3}{|c|}{$\begin{array}{c}\text { AM } \\
\text { (cm/planta) }\end{array}$} & \multicolumn{3}{|c|}{$\begin{array}{c}\mathrm{AC}^{1} \\
\text { (notas: } 1 \text { a } 5)\end{array}$} & \multicolumn{3}{|c|}{$\begin{array}{l}\text { DM } \\
\text { (dias) }\end{array}$} & \multicolumn{3}{|c|}{$\begin{array}{c}P G \\
\text { (g/parcela) }\end{array}$} \\
\hline & GL & QM & & GL & QM & & $\mathrm{GL}$ & QM & & GL & QM & \\
\hline Anos/C & 15 & 661,77 & & 15 & 1,5554 & & 15 & $13.921,550$ & & 15 & $331.413,3$ & \\
\hline Linh./C & 84 & $3.961,51$ & $* *$ & 84 & 1,0247 & ** & 84 & 364,065 & ** & 84 & $58.284,1$ & ** \\
\hline$(\mathrm{L} \times \mathrm{A}) / \mathrm{C}$ & 252 & 241,13 & ** & 252 & 0,1174 & ** & 252 & 64,854 & ** & 252 & $16.219,9$ & ** \\
\hline $\begin{array}{l}\text { Resíduo } \\
\text { Médio }\end{array}$ & 1.251 & 61,00 & & 1.248 & 0,0420 & & 1.251 & 9,857 & & 1.236 & $6.611,5$ & \\
\hline
\end{tabular}

** Significativo a $1 \%$ de probabilidade.

${ }^{1}$ Análise realizada com dados transformados para $\sqrt{x+0,5}$.

Tabela 5. Estimativas dos coeficientes de variação experimental ( $\mathrm{CVe} \%$ ) em cada um dos anos de experimentação e nas análises conjuntas, para os caracteres altura da planta na maturação (AM), acamamento (AC), número de dias para maturação (DM) e produção de grãos (PG).

\begin{tabular}{ccccc}
\hline \multirow{2}{*}{ Ano } & \multicolumn{5}{c}{ Caráter } \\
\cline { 2 - 5 } & AM & AC & DM & PG \\
\hline $1995 / 96$ & 11,93 & 15,40 & 1,92 & 30,72 \\
$1996 / 97$ & 9,68 & 21,32 & 1,63 & 22,10 \\
$1998 / 99$ & 7,69 & 12,22 & 2,58 & 28,61 \\
$1999 / 00$ & 8,33 & 12,19 & 2,23 & 35,96 \\
Conjunta & 8,95 & 14,55 & 2,28 & 30,33 \\
\hline
\end{tabular}


Tabela 6. Estimativas das variâncias genética aditiva entre linhagens $\left(\hat{\sigma}_{L}^{2}\right)$ e do erro experimental entre parcelas $\left(\hat{\sigma}^{2}\right)$, com seus respectivos intervalos de confiança para os caracteres altura da planta na maturação (AM), acamamento (AC), número de dias para maturação (DM) e produção de grãos (PG), nos anos 1995/96, 1996/97, 1998/99 e 1999/00.

\begin{tabular}{|c|c|c|c|c|c|}
\hline Caráter & Estimativas & $1995 / 96$ & $1996 / 97$ & $1998 / 99$ & $1999 / 00$ \\
\hline \multirow{6}{*}{$\begin{array}{c}\text { AM } \\
\text { (cm/planta) }\end{array}$} & LS & 209,2 & 292,7 & 401,0 & 524,3 \\
\hline & $\hat{\sigma}_{\mathrm{L}}^{2}$ & 136,2 & 204,4 & 286,3 & 374,7 \\
\hline & $\mathrm{LI}$ & 95,8 & 150,9 & 214,7 & 281,2 \\
\hline & LS & 136,3 & 85,3 & 52,4 & 60,4 \\
\hline & $\hat{\sigma}^{2}$ & 108,1 & 71,0 & 45,6 & 52,5 \\
\hline & LI & 87,8 & 60,1 & 40,0 & 46,1 \\
\hline \multirow{6}{*}{$\begin{array}{c}\mathrm{AC} \\
\text { (notas: } 1 \text { a } 5 \text { ) }\end{array}$} & LS & 0,0749 & 0,0989 & 0,1089 & 0,1251 \\
\hline & $\hat{\sigma}_{\mathrm{L}}^{2}$ & 0,0451 & 0,0643 & 0,0767 & 0,0884 \\
\hline & LI & 0,0301 & 0,0452 & 0,0569 & 0,0658 \\
\hline & LS & 0,0766 & 0,0844 & 0,0343 & 0,0344 \\
\hline & $\hat{\sigma}^{2}$ & 0,0607 & 0,0703 & 0,0298 & 0,0299 \\
\hline & LI & 0,0494 & 0,0595 & 0,0261 & 0,0263 \\
\hline \multirow{6}{*}{$\begin{array}{l}\mathrm{DM} \\
\text { (dias) }\end{array}$} & LS & 12,90 & 8,90 & 79,92 & 64,44 \\
\hline & $\hat{\sigma}_{\mathrm{L}}^{2}$ & 8,49 & 6,05 & 56,72 & 45,84 \\
\hline & LI & 6,02 & 4,38 & 42,35 & 34,28 \\
\hline & LS & 7,64 & 4,62 & 16,83 & 11,65 \\
\hline & $\hat{\sigma}^{2}$ & 6,05 & 3,84 & 14,63 & 10,13 \\
\hline & LI & 4,92 & 3,25 & 12,84 & 8,89 \\
\hline \multirow{6}{*}{$\begin{array}{c}P G \\
\text { (g/parcela) }\end{array}$} & LS & $5.499,6$ & $2.476,8$ & $14.426,2$ & $6.641,7$ \\
\hline & $\hat{\sigma}_{\mathrm{L}}^{2}$ & $3.376,7$ & $1.395,2$ & $9.796,4$ & $4.369,4$ \\
\hline & LI & $2.283,6$ & 894,4 & $7.088,3$ & $3.093,1$ \\
\hline & LS & $5.179,5$ & $4.143,4$ & $11.041,0$ & $7.458,3$ \\
\hline & $\hat{\sigma}^{2}$ & $4.103,8$ & $3.447,6$ & $9.593,1$ & $6.473,3$ \\
\hline & LI & $3.332,5$ & $2.913,9$ & $8.413,4$ & $5.672,0$ \\
\hline
\end{tabular}


Tabela 7. Estimativas das variâncias genética aditiva entre linhagens $\left(\hat{\sigma}_{L}^{2}\right)$, da interação entre linhagens e anos $\left(\hat{\sigma}_{L A}^{2}\right)$ e do erro experimental entre parcelas $\left(\hat{\sigma}^{2}\right)$, com seus respectivos intervalos de confiança para os caracteres altura da planta na maturação $(\mathrm{AM})$, acamamento $(\mathrm{AC})$, número de dias para maturação (DM) e produção de grãos (PG), obtidas das análises de variância conjuntas dos quatro anos.

\begin{tabular}{ccccc}
\hline Estimativas & $\begin{array}{c}\text { AM } \\
\text { (cm/planta) }\end{array}$ & $\begin{array}{c}\text { AC } \\
\text { (notas: } 1 \text { a } 5)\end{array}$ & $\begin{array}{c}\text { DM } \\
\text { (dias) }\end{array}$ & $\begin{array}{c}\text { PG } \\
\text { (g/parcela) }\end{array}$ \\
\hline LS & 302,7 & 0,0756 & 25,78 & $3.877,2$ \\
$\hat{\sigma}_{\text {L }}^{2}$ & 213,1 & 0,0520 & 17,14 & $2.409,9$ \\
LI & 158,2 & 0,0379 & 12,22 & $1.642,8$ \\
LS & 53,0 & 0,0232 & 15,67 & $3.045,5$ \\
$\hat{\sigma}_{\text {LA }}^{2}$ & 41,3 & 0,0173 & 12,60 & $2.201,9$ \\
LI & 33,1 & 0,0134 & 10,36 & $1.666,6$ \\
& & & & \\
LS & 66,1 & 0,0454 & 10,68 & $7.165,4$ \\
$\hat{\sigma}^{2}$ & 61,0 & 0,0420 & 9,86 & $6.611,5$ \\
LI & 56,5 & 0,0388 & 9,13 & $6.119,7$ \\
\hline
\end{tabular}


Tabela 8. Estimativas dos coeficientes de herdabilidade no sentido restrito entre médias de linhagens ( $h \frac{2}{\bar{x}} \%$ ) e seus respectivos intervalos de confiança, em cada um dos anos de experimentação e nas análises conjuntas, para os caracteres altura da planta na maturação (AM), acamamento (AC), número de dias para maturação (DM) e produção de grãos (PG).

\begin{tabular}{ccccccc}
\hline Caráter & Estimativas & $1995 / 96$ & $1996 / 97$ & $1998 / 99$ & $1999 / 00$ & Conjunta \\
\hline \multirow{2}{*}{ AM } & LS & 85,5 & 94,3 & 98,1 & 98,3 & 95,7 \\
(cm/planta) & $\mathrm{h}_{\overline{\mathrm{x}}}^{2}$ & 79,1 & 92,0 & 97,4 & 97,7 & 93,9 \\
& $\mathrm{LI}$ & 69,2 & 88,5 & 96,3 & 96,8 & 91,2 \\
& & & & & & \\
AC & LS & 78,5 & 84,7 & 95,6 & 96,1 & 91,8 \\
(notas:1 a 5) & $\mathrm{h}_{\overline{\mathrm{x}}}^{2}$ & 69,0 & 78,5 & 93,9 & 94,7 & 88,6 \\
& LI & 54,4 & 69,0 & 91,4 & 92,4 & 83,5 \\
& LS & 86,7 & 90,2 & 97,0 & 97,4 & 87,3 \\
DM & $\mathrm{h}_{\overline{\mathrm{x}}}^{2}$ & 80,8 & 86,3 & 95,9 & 96,5 & 82,2 \\
(dias) & LI & 71,7 & 80,2 & 94,1 & 95,0 & 74,3 \\
& & & & & & \\
PG & LS & 80,0 & 72,7 & 89,8 & 85,6 & 80,1 \\
(g/parcela) & $\mathrm{h}_{\overline{\mathrm{x}}}^{2}$ & 71,2 & 61,8 & 86,0 & 80,2 & 72,2 \\
& LI & 57,5 & 44,9 & 80,1 & 71,8 & 59,9 \\
\hline
\end{tabular}


Tabela 9. Estimativas dos coeficientes de variação genéticos (CVg\%) em cada um dos anos de experimentação e nas análises conjuntas para os caracteres altura da planta na maturação (AM), acamamento ( $\mathrm{AC})$, número de dias para maturação (DM) e produção de grãos (PG).

\begin{tabular}{ccccc}
\hline \multirow{2}{*}{ Ano } & \multicolumn{4}{c}{ Caráter } \\
\cline { 2 - 5 } & $\begin{array}{c}\text { AM } \\
\text { (cm/planta) }\end{array}$ & $\begin{array}{c}\text { AC } \\
\text { (notas: 1 a 5) }\end{array}$ & $\begin{array}{c}\text { DM } \\
\text { (dias) }\end{array}$ & $\begin{array}{c}\text { PG } \\
\text { (g/parcela) }\end{array}$ \\
\hline $1995 / 96$ & 13,39 & 13,26 & 2,27 & 27,86 \\
$1996 / 97$ & 16,41 & 20,39 & 2,05 & 14,06 \\
$1998 / 99$ & 19,27 & 19,61 & 5,08 & 28,91 \\
$1999 / 00$ & 22,25 & 20,95 & 4,74 & 29,55 \\
Conjunta & 16,72 & 16,19 & 3,01 & 18,31 \\
\hline
\end{tabular}


Tabela 10. Estimativas das covariâncias genéticas aditivas $\left(\operatorname{Cov}_{A}\right)$ e fenotípicas entre médias de linhagens $\left(\operatorname{Cov}_{\bar{F}}\right)$, acima e abaixo da diagonal, respectivamente, em cada um dos anos de experimentação e nas análises conjuntas, entre os caracteres altura da planta na maturação $(A M)$, acamamento $(A C)$, número de dias para maturação (DM) e produção de grãos (PG).

\begin{tabular}{|c|c|c|c|c|c|}
\hline \multirow{2}{*}{ Ano } & \multirow{2}{*}{ Caráter } & \multicolumn{4}{|c|}{ Caráter } \\
\hline & & AM & $A C$ & DM & $P G$ \\
\hline \multirow{4}{*}{$1995 / 96$} & AM & - & 1,2463 & 10,8837 & 25,7182 \\
\hline & $A C$ & 1,2997 & - & $-0,0424$ & $-4,9322$ \\
\hline & $\mathrm{DM}$ & 11,1641 & $-0,0410$ & - & 92,8015 \\
\hline & $P G$ & 67,9927 & $-5,4645$ & 94,2983 & - \\
\hline \multirow{4}{*}{$1996 / 97$} & AM & - & 2,1972 & 20,6455 & $-222,8836$ \\
\hline & $A C$ & 2,2269 & - & 0,0472 & $-5,9478$ \\
\hline & $\mathrm{DM}$ & 20,5197 & 0,0159 & - & 10,3731 \\
\hline & $P G$ & $-198,0001$ & $-6,5177$ & 9,7132 & - \\
\hline \multirow{4}{*}{$1998 / 99$} & AM & - & 1,5136 & 62,3723 & 764,9718 \\
\hline & $A C$ & 1,5678 & - & 0,4054 & $-18,2470$ \\
\hline & $\mathrm{DM}$ & 62,3960 & 0,4163 & - & 376,2804 \\
\hline & $P G$ & 780,5678 & $-12,7511$ & 378,9880 & - \\
\hline \multirow{4}{*}{$1999 / 00$} & AM & - & 3,1627 & 79,1745 & 568,3309 \\
\hline & $A C$ & 3,1830 & - & 0,8734 & $-6,0912$ \\
\hline & $\mathrm{DM}$ & 79,9589 & 0,8828 & - & 86,1231 \\
\hline & $P G$ & 572,5515 & $-6,2057$ & 89,1193 & - \\
\hline \multirow{4}{*}{ Conjunta } & AM & - & 1,8031 & 35,2108 & 200,4880 \\
\hline & $A C$ & 1,8758 & - & 0,2250 & $-5,2027$ \\
\hline & DM & 37,2259 & 0,2487 & - & 101,4682 \\
\hline & $P G$ & 228,8404 & $-6,1582$ & 112,4002 & - \\
\hline
\end{tabular}


Tabela 11. Estimativas das correlações genéticas aditivas $\left(r_{A(X, Y)}\right)$ e correlações fenotípicas entre médias de linhagens $\left(r_{\bar{F}(X, Y)}\right)$, acima e abaixo da diagonal, respectivamente, entre os caracteres altura da planta na maturação (AM), acamamento (AC), número de dias para maturação (DM) e produção de grãos (PG), obtidas a partir das análises individuais e conjuntas dos quatro anos de avaliação.

\begin{tabular}{|c|c|c|c|c|c|}
\hline \multirow{2}{*}{ Caráter } & \multirow{2}{*}{ Anos } & \multicolumn{4}{|c|}{ Caráter } \\
\hline & & AM & $A C$ & DM & $P G$ \\
\hline \multirow{5}{*}{$\begin{array}{c}\mathrm{AM} \\
\text { (cm/planta) }\end{array}$} & $1995 / 96$ & & $+0,503$ & $+0,320$ & $+0,038$ \\
\hline & 1996/97 & & $+0,606$ & $+0,587$ & $-0,417$ \\
\hline & 1998/99 & & $+0,323$ & $+0,489$ & $+0,457$ \\
\hline & 1999/00 & & $+0,550$ & $+0,604$ & $+0,444$ \\
\hline & Conjunta & & $+0,542$ & $+0,583$ & $+0,280$ \\
\hline \multirow{5}{*}{$\begin{array}{c}\mathrm{AC} \\
\text { (notas: } 1 \text { a } 5)\end{array}$} & 1995/96 & $+0,387$ & & $-0,069$ & $-0,400$ \\
\hline & $1996 / 97$ & $+0,522$ & & $+0,076$ & $-0,628$ \\
\hline & 1998/99 & $+0,320$ & & $+0,194$ & $-0,666$ \\
\hline & 1999/00 & $+0,532$ & & $+0,434$ & $-0,310$ \\
\hline & Conjunta & $+0,514$ & & $+0,238$ & $-0,465$ \\
\hline \multirow{5}{*}{$\begin{array}{l}\text { DM } \\
\text { (dias) }\end{array}$} & $1995 / 96$ & $+0,262$ & $-0,049$ & & $+0,548$ \\
\hline & $1996 / 97$ & $+0,520$ & $+0,021$ & & $+0,113$ \\
\hline & 1998/99 & $+0,473$ & $+0,189$ & & $+0,505$ \\
\hline & 1999/00 & $+0,592$ & $+0,419$ & & $+0,192$ \\
\hline & Conjunta & $+0,541$ & $+0,225$ & & $+0,499$ \\
\hline \multirow{5}{*}{$\begin{array}{c}P G \\
\text { (g/parcela) }\end{array}$} & 1995/96 & $+0,075$ & $-0,310$ & $+0,422$ & \\
\hline & 1996/97 & $-0,280$ & $-0,479$ & $+0,077$ & \\
\hline & 1998/99 & $+0,427$ & $-0,418$ & $+0,462$ & \\
\hline & 1999/00 & $+0,396$ & $-0,275$ & $+0,175$ & \\
\hline & Conjunta & $+0,263$ & $-0,440$ & $+0,426$ & \\
\hline
\end{tabular}


Tabela 12. Estimativas da média da população original $\left(\bar{X}_{\mathrm{p}}\right)$, média das linhagens selecionadas $\left(\bar{X}_{s}\right)$, média das testemunhas $\left(\bar{X}_{t}\right)$, do coeficiente de herdabilidade $\left(h_{\bar{X}}^{2}\right)$, do ganho esperado com seleção (Gs), do ganho esperado com seleção em percentual da população original $\left(\mathrm{Gs}_{\mathrm{p}} \%\right)$ e do ganho esperado com seleção em percentual das testemunhas $\left(\mathrm{Gs}_{\mathrm{t}} \%\right)$, para os caracteres altura da planta na maturação (AM) e produção de grãos (PG), com base nos quatro anos de experimentação individualmente e nas médias dos anos 1 e 2; 1, 2 e 3; e 1, 2, 3 e 4; considerando uma intensidade de seleção de $20 \%$.

\begin{tabular}{lccccccc}
\hline \multicolumn{1}{c}{ Ano } & $\bar{X}_{p}$ & $\bar{X}_{s}$ & $\bar{X}_{t}$ & $h_{\bar{X}}^{2} \%$ & $G s$ & $G_{p} \%$ & $G s_{t} \%$ \\
\hline \multicolumn{7}{c}{ Altura da Planta na Maturação } \\
1995/96 (1) & 87,1 & 109,1 & 92,4 & 79,1 & 17,40 & 19,98 & 18,83 \\
1996/97 (2) & 87,0 & 110,0 & 89,9 & 92,0 & 21,16 & 24,32 & 23,54 \\
1998/99 (3) & 87,8 & 116,7 & 93,8 & 97,4 & 28,15 & 32,06 & 30,01 \\
1999/00 (4) & 87,0 & 120,6 & 93,0 & 97,7 & 32,83 & 37,74 & 35,30 \\
Anos 1 e 2 & 87,1 & 108,6 & 91,2 & 94,2 & 20,26 & 23,26 & 22,22 \\
Anos 1, 2 e 3 & 87,3 & 110,2 & 92,0 & 92,5 & 21,19 & 24,27 & 23,03 \\
Anos 1, 2, 3 e 4 & 87,3 & 112,4 & 92,3 & 93,9 & 23,57 & 27,00 & 25,54 \\
& & & & & & \\
& & & & & & \\
1995/96 (1) & 207,7 & 307,9 & 257,0 & 71,2 & 71,31 & 34,33 & 27,75 \\
1996/97 (2) & 265,3 & 331,8 & 327,3 & 61,8 & 41,11 & 15,49 & 12,56 \\
1998/99 (3) & 341,6 & 498,9 & 425,3 & 86,0 & 135,23 & 39,59 & 31,80 \\
1999/00 (4) & 223,0 & 330,1 & 325,6 & 80,2 & 85,89 & 38,52 & 26,38 \\
Anos 1 e 2 & 236,5 & 311,0 & 292,2 & 61,6 & 45,92 & 19,42 & 15,72 \\
Anos 1, 2 e 3 & 271,6 & 351,7 & 336,5 & 55,4 & 44,41 & 16,35 & 13,20 \\
Anos 1, 2, 3 e 4 & 259,4 & 338,9 & 333,8 & 72,2 & 57,38 & 22,12 & 17,19 \\
\hline
\end{tabular}


Tabela 13. Médias das linhagens para o caráter altura da planta na maturação (AM), em $\mathrm{cm} /$ planta, para os quatro anos e para as combinações sucessivas dos anos.

\begin{tabular}{|c|c|c|c|c|c|c|c|c|c|c|c|c|c|c|}
\hline \multirow{2}{*}{ Linhagem } & \multicolumn{14}{|c|}{ Ano } \\
\hline & \multicolumn{2}{|c|}{$\begin{array}{l}1995 / 96(1) \\
\end{array}$} & \multicolumn{2}{|c|}{$\begin{array}{l}1996 / 97(2) \\
\end{array}$} & \multicolumn{2}{|c|}{ 1998/99(3) } & \multicolumn{2}{|c|}{ 1999/00(4) } & \multicolumn{2}{|l|}{1,2} & \multicolumn{2}{|c|}{$1,2,3$} & \multicolumn{2}{|l|}{$1,2,3,4$} \\
\hline 50 & 125,0 & 01 & 122,5 & 02 & 130,5 & 04 & 133,7 & 03 & 123,8 & 01 & 126,0 & 01 & 127,9 & \\
\hline 41 & 121,7 & 03 & 119,8 & 04 & 127,2 & 05 & 133,8 & 02 & 120,7 & 03 & 122,9 & 04 & 125,6 & \\
\hline 72 & 118,3 & 04 & 119,3 & 05 & 133,8 & 01 & 131,0 & 04 & 118,8 & 05 & 123,8 & 03 & 125,6 & \\
\hline 34 & 123,3 & 02 & 122,0 & 03 & 120,7 & 09 & 135,0 & 01 & 122,7 & 02 & 122,0 & 05 & 125,3 & \\
\hline 93 & 116,7 & 05 & 123,5 & 01 & 132,2 & 03 & 121,7 & 10 & 120,1 & 04 & 124,1 & 02 & 123,5 & \\
\hline 84 & 115,0 & 06 & 116,8 & 06 & 127,2 & 06 & 129,7 & 05 & 115,9 & 06 & 119,6 & 06 & 122,1 & \\
\hline 74 & 106,7 & 12 & 111,0 & 08 & 124,5 & 08 & 123,3 & 09 & 108,8 & 08 & 114,1 & 08 & 116,4 & \\
\hline 33 & 111,7 & 08 & 111,0 & 07 & 133,5 & 02 & 102,3 & 18 & 111,3 & 07 & 118,7 & 07 & 114,6 & \\
\hline 76 & 108,3 & 10 & 98,5 & 20 & 126,7 & 07 & 124,5 & 06 & 103,4 & 12 & 111,2 & 09 & 114,5 & \\
\hline 15 & 101,7 & 13 & 106,0 & 11 & 117,5 & 10 & 119,7 & 11 & 103,8 & 11 & 108,4 & 10 & 111,2 & \\
\hline 02 & 107,0 & 11 & 105,3 & 12 & 107,0 & 13 & 112,0 & 14 & 106,1 & 10 & 106,4 & 11 & 107,8 & \\
\hline 66 & 96,7 & 16 & 105,0 & 13 & 94,3 & 20 & 124,3 & 07 & 100,8 & 13 & 98,7 & 14 & 105,1 & \\
\hline 40 & 108,3 & 09 & 106,5 & 10 & 91,8 & 23 & 105,5 & 17 & 107,4 & 09 & 102,2 & 12 & 103,0 & \\
\hline 24 & 90,3 & 22 & 101,5 & 14 & 95,5 & 19 & 119,5 & 12 & 95,9 & 17 & 95,8 & 17 & 101,7 & \\
\hline 5 & 100,0 & 15 & 100,5 & 17 & 102,2 & 14 & 99,7 & 22 & 100,3 & 15 & 100,9 & 13 & 100,6 & \\
\hline 6 & 83,3 & 55 & 82,0 & 47 & 111,8 & 12 & 124,0 & 08 & 82,7 & 49 & 92,4 & 22 & 100,3 & \\
\hline 6 & 86,7 & 37 & 90,0 & 31 & 114,5 & 11 & 107,3 & 16 & 88,3 & 31 & 97,1 & 15 & 99,6 & \\
\hline 0 & 76,7 & 73 & 108,5 & 09 & 99,2 & 15 & 110,7 & 15 & 92,6 & 21 & 94,8 & 20 & 98,8 & \\
\hline 2 & 87,8 & 32 & 101,0 & 16 & 95,8 & 18 & 102,3 & 19 & 94,4 & 19 & 94,9 & 19 & 96,7 & \\
\hline 6 & 83,3 & 54 & 87,5 & 35 & 90,3 & 27 & 113,3 & 13 & 85,4 & 42 & 87,1 & 36 & 93,6 & \\
\hline & 100,0 & 14 & 101,0 & 15 & 89,5 & 29 & 83,5 & 39 & 100,5 & 14 & 8 & 16 & & \\
\hline 5 & 3,3 & 53 & 99,5 & 18 & 89,2 & 30 & 102,0 & 20 & 91,4 & 24 & 90,7 & 27 & 3,5 & \\
\hline 3 & 87,8 & 31 & 93,0 & 27 & 90,3 & 26 & 100,7 & 21 & 90,4 & 26 & 90,4 & 29 & 92,9 & \\
\hline & 88,3 & 30 & 95,3 & 24 & 94,2 & 21 & 90,7 & 25 & 91,8 & & 92,6 & & 2,1 & \\
\hline 5 & 85,0 & 47 & 97,3 & 21 & 91,0 & 25 & 93,3 & 23 & 91,1 & 2 & 91,1 & 26 & 91,6 & \\
\hline & & 21 & 95,8 & 23 & 89,7 & 28 & 86,3 & 35 & 93,7 & 2 & 92,4 & 20 & & \\
\hline 2 & 114,3 & 07 & 85,0 & 42 & 87,7 & 32 & 75,8 & 60 & 99,6 & 16 & 95,6 & 18 & 90,7 & \\
\hline 2 & 85,0 & 46 & 87,8 & 34 & 99,0 & 16 & 87,3 & 33 & 86,4 & 38 & 90,6 & 88 & 89,8 & \\
\hline & & 45 & 99,0 & 19 & & 24 & 79,7 & 49 & & 22 & 91,7 & &, 7 & \\
\hline 2 & 88,3 & 29 & 88,0 & 33 & 86,0 & 37 & 90,0 & 28 & 88,2 & 34 & 87,4 & 34 & 88,1 & \\
\hline & 2,0 & 57 & 94,5 & 26 & & 34 & 87,7 & 32 & 88,3 & 3 & 87,7 & 32 & 87,7 & \\
\hline$c$ & 0 & 24 & 90,3 & 30 & 80,0 & 54 & 89,8 & 29 & 90,1 & 2 & 86,8 & & 87,5 & \\
\hline 9 & 5,0 & 44 & 94,8 & 25 & 86,5 & 33 & 83,3 & 40 & 89,9 & 2 & 88,8 & 0 & 87,4 & \\
\hline & & 23 & & 38 & & 43 & & 24 & & & & & 87,4 & \\
\hline I & 83,3 & 52 & 90,8 & 29 & 81,8 & 45 & 90,5 & 27 & 87,0 & 3 & 85,3 & 1 & 86,6 & \\
\hline 4 & 91,7 & 20 & 87,3 & 36 & 83 & 39 & 78,8 & 51 & 89 & & 87,6 & & 85,4 & \\
\hline 1 & 85,0 & 43 & 86,3 & 40 & 80,8 & 49 & 88,2 & 30 & 85,6 & 4 & 84,0 & & 85,1 & \\
\hline 9 & 95,0 & 17 & 96,0 & 22 & 83,2 & 40 & 65,5 & 84 & 95,5 & 18 & 91,4 & 25 & 84,9 & \\
\hline 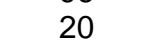 & 80,0 & 64 & 81,8 & 52 & 92,7 & 22 & 84,5 & 36 & 80,9 & 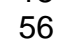 & 84,8 & 42 & 84,7 & \\
\hline 8 & 86,7 & 36 & 91,0 & 28 & 86,0 & 36 & 75,0 & 62 & 88,8 & 3 & 87,9 & & 84,7 & \\
\hline 6 & 81,7 & 62 & 78,8 & 66 & & 17 & & 47 & 80,2 & & & & 84,6 & \\
\hline 5 & 83,3 & 51 & 85,3 & 41 & 81,8 & 46 & 83 & 41 & 84 & 4 & 83,5 & 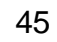 & 83,4 & \\
\hline 0 & 81,7 & 61 & 81,0 & 58 & 79,3 & 57 & 90,7 & 26 & 81,3 & 5 & 80,7 & 55 & 83,2 & \\
\hline & 91,7 & 19 & 80,8 & 59 & 89,0 & 31 & 68,0 & 78 & 86,2 & 39 & 87,1 & 35 & 82,4 & \\
\hline 9 & & 35 & 86,5 & 39 & 76,2 & 71 & 77 & 54 & 86,6 & 3 & 83,1 & 46 & 7 & \\
\hline 0 & 86 & 34 & 81,5 & 55 & 75,0 & 73 & 83,0 & 42 & 84,1 & 4 & 81,1 & 52 & 81,5 & \\
\hline & & 12 & 00 & 49 & & $3 \varepsilon$ & & 46 & 9.3 & 63 & 81.2 & 50 & 81,3 & \\
\hline
\end{tabular}


Tabela 13. Médias das linhagens para o caráter altura da planta na maturação (AM), em $\mathrm{cm} /$ planta, para os quatro anos e para as combinações sucessivas dos anos.

\begin{tabular}{|c|c|c|c|c|c|c|c|c|c|c|c|c|c|c|}
\hline \multirow{2}{*}{ Linhagem } & \multicolumn{14}{|c|}{ Ano } \\
\hline & \multicolumn{2}{|c|}{$1995 / 96(1)$} & \multicolumn{2}{|c|}{ 1996/97(2) } & \multicolumn{2}{|c|}{$\begin{array}{l}1998 / 99(3) \\
\end{array}$} & \multicolumn{2}{|c|}{ 1999/00(4) } & \multicolumn{2}{|l|}{1,2} & \multicolumn{2}{|c|}{$1,2,3$} & \multicolumn{2}{|c|}{$1,2,3,4$} \\
\hline 64 & 93,3 & 18 & 82,5 & 45 & 80,3 & 53 & 67,3 & 80 & 87,9 & 35 & 85,4 & 40 & 80,9 & 48 \\
\hline 95 & 88,7 & 25 & 80,8 & 60 & 82,0 & 44 & 71,2 & 70 & 84,7 & 43 & 83,8 & 44 & 80,6 & 49 \\
\hline 26 & 83,3 & 50 & 80,5 & 62 & 75,0 & 74 & 82,0 & 44 & 81,9 & 53 & 79,6 & 60 & 80,2 & 51 \\
\hline 81 & 83,3 & 49 & 81,3 & 57 & 82,5 & 41 & 72,8 & 67 & 82,3 & 51 & 82,4 & 47 & 80,0 & 53 \\
\hline 89 & 78,0 & 68 & 81,8 & 53 & 82,3 & 42 & 77,8 & 52 & 79,9 & 60 & 80,7 & 54 & 80,0 & 52 \\
\hline 31 & 82,8 & 56 & 81,9 & 50 & 79,7 & 56 & 75,3 & 61 & 82,3 & 50 & 81,5 & 48 & 79,9 & 50 \\
\hline 77 & 75,0 & 79 & 77,5 & 71 & 79,3 & 58 & 87,0 & 34 & 76,3 & 76 & 77,3 & 68 & 79,7 & 54 \\
\hline 10 & 78,3 & 67 & 79,8 & 64 & 78,7 & 59 & 81,7 & 45 & 79,0 & 65 & 78,9 & 63 & 79,6 & 55 \\
\hline 39 & 76,7 & 71 & 80,0 & 63 & 80,8 & 50 & 80,5 & 48 & 78,3 & 69 & 79,2 & 62 & 79,5 & 56 \\
\hline 13 & 85,0 & 42 & 80,8 & 61 & 72,3 & 80 & 79,7 & 50 & 82,9 & 48 & 79,4 & 61 & 79,4 & 57 \\
\hline 49 & 81,7 & 60 & 77,5 & 69 & 81,2 & 48 & 76,2 & 57 & 79,6 & 61 & 80,1 & 57 & 79,1 & 58 \\
\hline 98 & 86,7 & 33 & 77,3 & 72 & 76,3 & 70 & 76,0 & 59 & 82,0 & 52 & 80,1 & 58 & 79,1 & 59 \\
\hline 46 & 88,3 & 28 & 82,5 & 46 & 73,0 & 78 & 70,0 & 73 & 85,4 & 41 & 81,3 & 49 & 78,5 & 60 \\
\hline 19 & 76,7 & 70 & 82,0 & 48 & 72,2 & 81 & 82,8 & 43 & 79,3 & 62 & 76,9 & 71 & 78,4 & 61 \\
\hline 37 & 78,3 & 66 & 68,5 & 82 & 78,5 & 62 & 87,8 & 31 & 73,4 & 80 & 75,1 & 80 & 78,3 & 62 \\
\hline 92 & 76,3 & 74 & 77,5 & 70 & 81,8 & 47 & 77,0 & 56 & 76,9 & 74 & 78,5 & 65 & 78,1 & 64 \\
\hline 90 & 75,3 & 77 & 81,8 & 54 & 86,5 & 35 & 69,0 & 76 & 78,5 & 68 & 81,2 & 51 & 78,1 & 63 \\
\hline 03 & 85,0 & 41 & 81,8 & 51 & 76,0 & 72 & 69,0 & 77 & 83,4 & 47 & 80,9 & 53 & 77,9 & 65 \\
\hline 18 & 85,7 & 38 & 81,5 & 56 & 72,2 & 82 & 72,2 & 68 & 83,6 & 46 & 79,8 & 59 & 77,9 & 66 \\
\hline 71 & 73,3 & 83 & 72,5 & 75 & 80,7 & 51 & 83,8 & 38 & 72,9 & 82 & 75,5 & 77 & 77,6 & 67 \\
\hline 12 & 71,7 & 85 & 88,3 & 32 & 76,3 & 69 & 73,7 & 64 & 80,0 & 59 & 78,8 & 64 & 77,5 & 68 \\
\hline 30 & 70,0 & 87 & 87,3 & 37 & 74,5 & 76 & 77,3 & 55 & 78,6 & 67 & 77,3 & 69 & 77,3 & 69 \\
\hline 58 & 88,3 & 27 & 69,3 & 81 & 77,7 & 63 & 73,7 & 63 & 78,8 & 66 & 78,4 & 66 & 77,2 & 70 \\
\hline 85 & 80,0 & 63 & 83,0 & 43 & 78,5 & 60 & 65,7 & 83 & 81,5 & 54 & 80,5 & 56 & 76,8 & 72 \\
\hline 32 & 75,8 & 75 & 78,8 & 67 & 78,5 & 61 & 73,5 & 65 & 77,3 & 73 & 77,7 & 67 & 76,6 & 71 \\
\hline 42 & 85,0 & 40 & 70,0 & 79 & 67,0 & 88 & 84,5 & 37 & 77,5 & 71 & 74,0 & 81 & 76,6 & 73 \\
\hline 21 & 81,7 & 59 & 73,0 & 74 & 73,3 & 77 & 76,2 & 58 & 77,3 & 72 & 76,0 & 75 & 76,0 & 74 \\
\hline 47 & 88,3 & 26 & 72,0 & 78 & 70,5 & 85 & 73,2 & 66 & 80,2 & 58 & 76,9 & 72 & 76,0 & 75 \\
\hline 08 & 73,3 & 82 & 79,8 & 65 & 77,3 & 65 & 71,0 & 72 & 76,5 & 75 & 76,8 & 73 & 75,4 & 76 \\
\hline 97 & 70.0 & 86 & 70.0 & 80 & 80.5 & 52 & 77.8 & 53 & 70.0 & 86 & 73,5 & 83 & 74.6 & 77 \\
\hline 57 & 81,7 & 58 & 67,5 & 83 & 77,5 & 64 & 71,0 & 71 & 74,6 & 77 & 75,6 & 76 & 74,4 & 78 \\
\hline 70 & 78,3 & 65 & 77,8 & 68 & 75,0 & 75 & 66,5 & 81 & 78,0 & 70 & 77,0 & 70 & 74,4 & 79 \\
\hline 11 & 63,3 & 89 & 82,8 & 44 & 79,7 & 55 & 69,2 & 75 & 73,0 & 81 & 75,3 & 78 & 73,7 & 80 \\
\hline 99 & 85,0 & 39 & 73,3 & 73 & 71,2 & 84 & 62,8 & 88 & 79,1 & 64 & 76,5 & 74 & 73,1 & 81 \\
\hline 86 & 83,3 & 48 & 65,3 & 86 & 76,8 & 67 & 65,8 & 82 & 74,3 & 78 & 75,1 & 79 & 72,8 & 82 \\
\hline 80 & 71,7 & 84 & 72,5 & 76 & 77,0 & 66 & 69,8 & 74 & 72,1 & 83 & 73,7 & 82 & 72,8 & 83 \\
\hline 28 & 76,7 & 69 & 65,3 & 87 & 70,2 & 86 & 71,5 & 69 & 71,0 & 85 & 70,7 & 85 & 70,9 & 84 \\
\hline 73 & 75,7 & 76 & 72,3 & 77 & 72,5 & 79 & 61,7 & 89 & 74,0 & 79 & 73,5 & 84 & 70,5 & 85 \\
\hline 68 & 73,3 & 81 & 66,0 & 85 & 71,7 & 83 & 63,8 & 87 & 69,7 & 87 & 70,3 & 86 & 68,7 & 86 \\
\hline 53 & 73,3 & 80 & 60,8 & 89 & 69,3 & 87 & 67,5 & 79 & 67,0 & 88 & 67,8 & 89 & 67,7 & 87 \\
\hline 51 & 68,0 & 88 & 62,0 & 88 & 76,7 & 68 & 63,8 & 86 & 65,0 & 89 & 68,9 & 87 & 67,6 & 88 \\
\hline 69 & 75,0 & 78 & 67,3 & 84 & 63,7 & 89 & 64,2 & 85 & 71,1 & 84 & 68,6 & 88 & 67,5 & 89 \\
\hline & & & & & & & & & & & & & & \\
\hline & 89,6 & & 84,6 & & 87,5 & & 88,8 & & 87,1 & & 87,2 & & 87,3 & \\
\hline IAC-F-31 & 112,1 & & 111,9 & & 126,6 & & 121,0 & & 112,0 & & 116,8 & & 119,3 & \\
\hline - & 75,6 & & 73,4 & & 67,2 & & 69,3 & & 74,5 & & 72,1 & & 70,2 & \\
\hline
\end{tabular}

Nota: As linhagens estão apresentadas em ordem decrescente, baseada nas médias de quatro anos. As médias destacadas em negrito correspondem às $20 \%$ superiores em cada critério. 
Tabela 14. Médias das linhagens para o caráter acamamento (AC), notas de 1 a 5 , para os quatro anos e para as combinações sucessivas dos anos.

\begin{tabular}{|c|c|c|c|c|c|c|c|c|c|c|c|c|c|c|}
\hline \multirow{2}{*}{ Linhagem } & \multicolumn{14}{|c|}{ Ano } \\
\hline & \multicolumn{2}{|c|}{ 1995/96(1) } & \multicolumn{2}{|c|}{ 1996/97(2) } & \multicolumn{2}{|c|}{ 1998/99(3) } & \multicolumn{2}{|c|}{ 1999/00(4) } & \multicolumn{2}{|l|}{1,2} & \multicolumn{2}{|c|}{$1,2,3$} & \multicolumn{2}{|c|}{$1,2,3,4$} \\
\hline 03 & 1,000 & 01 & 0,500 & 04 & 1,000 & 04 & 1,000 & 03 & 0,750 & 02 & 0,833 & 01 & 0,875 & \\
\hline 68 & 1,000 & 06 & 0,500 & 06 & 1,000 & 06 & 1,000 & 04 & 0,750 & 03 & 0,833 & 02 & 0,875 & \\
\hline 73 & 1,000 & 07 & 0,500 & 07 & 1,000 & 07 & 1,000 & 05 & 0,750 & 04 & 0,833 & 03 & 0,875 & \\
\hline 20 & 1,000 & 03 & 0,500 & 05 & 1,000 & 05 & 1,333 & 52 & 0,750 & 05 & 0,833 & 04 & 0,958 & \\
\hline & 1,000 & 05 & 0,750 & 22 & 1,000 & 14 & 1,167 & 44 & 0,875 & 07 & 0,917 & 06 & 0,979 & \\
\hline 16 & 1,000 & 02 & 0,750 & 21 & 1,167 & 38 & 1,000 & 24 & 0,875 & 06 & 0,972 & 07 & 0,979 & \\
\hline 47 & 1,667 & 27 & 0,250 & 02 & 1,000 & 03 & 1,000 & 02 & 0,958 & 09 & 0,972 & 09 & 0,979 & \\
\hline 69 & 1,333 & 16 & 0,750 & 25 & 1,000 & 15 & 1,000 & 11 & 1,042 & 11 & 1,028 & 10 & 1,021 & \\
\hline J & 1,333 & 17 & 0,750 & 26 & 1,000 & 16 & 1,000 & 12 & 1,042 & 12 & 1,028 & 11 & 1,021 & \\
\hline 3 & 1,013 & 10 & 0,446 & 03 & 1,167 & 33 & 1,500 & 60 & 0,729 & 01 & 0,875 & 05 & 1,031 & \\
\hline 80 & 1,667 & 36 & 0,500 & 14 & 1,000 & 09 & 1,000 & 06 & 1,083 & 14 & 1,056 & 13 & 1,042 & \\
\hline $0 \varepsilon$ & ,667 & 22 & 0,500 & 10 & 1,167 & 34 & 1,000 & 21 & 1,083 & 15 & 1,111 & 16 & 1,083 & \\
\hline 5 & 667 & 31 & 0,500 & 12 & 1,167 & 35 & 1,000 & 22 & 1,083 & 16 & 1,111 & 17 & 1,083 & \\
\hline 70 & 667 & 34 & 0,500 & 13 & 1,167 & 36 & 1,000 & 23 & 1,083 & 17 & 1,111 & 18 & 1,083 & \\
\hline 97 & 1,000 & 09 & 0,750 & 23 & 1,167 & 39 & 1,500 & 61 & & 08 & 0,972 & 08 & 1,104 & \\
\hline 2 & ,513 & 18 & 0,750 & 27 & 1,000 & 17 & 1,167 & 45 & 1,131 & 21 & 1,088 & 15 & 1,107 & \\
\hline $2 \xi$ & 667 & 24 & 0,500 & 11 & 1,000 & 08 & 1,333 & 53 & 1,083 & 20 & 56 & 14 & 1,125 & \\
\hline 04 & 1,667 & 20 & 0,500 & 08 & 1,333 & 53 & 1,000 & 32 & 1,083 & 18 & 1,167 & 23 & 1,125 & \\
\hline 05 & 1,667 & 21 & 0,500 & 09 & 1,333 & 54 & 1,000 & 33 & 1,083 & 19 & 1,167 & 24 & 1,125 & \\
\hline 8 & 1,000 & 08 & 1,500 & 63 & 1,000 & 27 & 1,000 & 16 & & 29 & 1,167 & 26 & 1,125 & \\
\hline 25 & 2, & 53 & 0,500 & 16 & 1,000 & 10 & 1,000 & 07 & 1,256 & 31 & & & 1,128 & \\
\hline 15 & 1,667 & 23 & 0,750 & 28 & 1,000 & 18 & 1,167 & 46 & 1,208 & 26 & 1,139 & 20 & 1,146 & \\
\hline 85 & 1,667 & 37 & 0,750 & 33 & 1,000 & 20 & 1,167 & 47 & 1,208 & 27 & 1,139 & 21 & 1,146 & \\
\hline 49 & 67 & 28 & 0,750 & 30 & 1,167 & 40 & 1,000 & 25 & & 23 & & 8 & 1,146 & \\
\hline 46 & 1,667 & 26 & 0,750 & 29 & 1,211 & 52 & 1,000 & 31 & 1,208 & 24 & 1,209 & 29 & 1,157 & \\
\hline & & 04 & & 48 & 1,167 & 45 & 1,500 & 62 & & 10 & & & 1,167 & \\
\hline 3 & 2,000 & 42 & 0,750 & 35 & 0,928 & 01 & 1,000 & 01 & & 34 & 1,226 & ? & 1,170 & \\
\hline 7 & & 35 & 0,7 & 32 & 1,000 & 19 & & 54 & & 28 & & 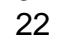 & ,188 & \\
\hline 8 & 0 & 52 & 0,7 & 40 & 1,000 & 21 & $1, \mathrm{C}$ & 13 & 1 & 35 & & 3 & 1,188 & \\
\hline 2 & 33 & 14 & 1,000 & 49 & 1,167 & 46 & 1,333 & 55 & 1,167 & 22 & 1,167 & 25 & 1,208 & \\
\hline 6 & & 58 & & 18 & & 11 & & 08 & & 41 & & & 08 & \\
\hline 86 & 3 & 60 & 0,500 & 19 & 1,000 & 12 & 1,0 & 09 & 1, & 42 & 78 & 35 & 1,208 & \\
\hline 29 & & 25 & & 50 & 1,000 & 24 & & 48 & & 32 & & 31 & 1,208 & \\
\hline & & 11 & & 24 & 1,333 & 55 & 1,5 & 63 & & 3 & & 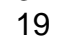 & 1,229 & \\
\hline 13 & 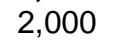 & 40 & 0,750 & 34 & 1,167 & 41 & 1,000 & 26 & & 36 & & 36 & 1,229 & \\
\hline-0 & & 49 & & 38 & & 13 & & 27 & & 27 & & & 1,229 & \\
\hline 4 & 0 & 46 & 0,750 & 37 & 1,3 & 56 & 1, & 34 & & 38 & 61 & 41 & 1,271 & \\
\hline 98 & & 63 & & 44 & 1,000 & 22 & & 14 & & 50 & & 43 & 1,271 & \\
\hline 34 & t) & 44 & 0,750 & 36 & 1,167 & 42 & & 49 & & 39 & & 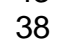 & 1,271 & \\
\hline 83 & 3,000 & 73 & 0,000 & 01 & 1,000 & 02 & 1,1 & 43 & & 46 & 1,333 & 39 & 1,292 & \\
\hline 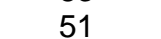 & & 29 & & 31 & & 70 & & 40 & & 5 & & T & 1,313 & \\
\hline 1 & & 12 & 2,0 & 75 & 1,000 & 30 & 1,0 & 18 & & 56 & & 48 & 1,333 & \\
\hline 18 & & 13 & 2,000 & 76 & 1,000 & 31 & & 19 & & 57 & & 49 & 1,333 & \\
\hline 67 & & 15 & 1,500 & 64 & 1,333 & 59 & 1,3 & 57 & & 44 & 1,389 & 44 & 1,375 & \\
\hline 91 & 3, & 75 & 0,500 & 20 & 1,000 & 13 & & 10 & & 61 & & 51 & 1,375 & \\
\hline 94 & 2,333 & 61 & 0,750 & 43 & 1,500 & 63 & 1,000 & 37 & 1,542 & 51 & 1,528 & 53 & 1,396 & \\
\hline$<1$ & & 65 & 0,150 & 45 & $1,16 /$ & 44 & 1,000 & 28 & 1,108 & 59 & 1,528 & 54 & 1,396 & \\
\hline
\end{tabular}


Tabela 14. Médias das linhagens para o caráter acamamento (AC), notas de 1 a 5 , para os quatro anos e para as combinações sucessivas dos anos.

\begin{tabular}{|c|c|c|c|c|c|c|c|c|c|c|c|c|c|c|}
\hline \multirow{2}{*}{ Linhagem } & \multicolumn{14}{|c|}{ Ano } \\
\hline & \multicolumn{2}{|c|}{ 1995/96(1) } & \multicolumn{2}{|c|}{$1996 / 97(2)$} & \multicolumn{2}{|c|}{ 1998/99(3) } & \multicolumn{2}{|c|}{$\begin{array}{l}1999 / 00(4) \\
\end{array}$} & \multicolumn{2}{|c|}{1,2} & \multicolumn{2}{|c|}{$1,2,3$} & \multicolumn{2}{|c|}{$1,2,3,4$} \\
\hline 53 & 2,000 & 47 & 1,250 & 58 & 1,500 & 65 & 1,000 & 38 & 1,625 & 54 & 1,583 & 56 & 1,438 & 48 \\
\hline 55 & 2,000 & 48 & 1,000 & 52 & 1,000 & 25 & 1,833 & 70 & 1,500 & 48 & 1,333 & 40 & 1,458 & 49 \\
\hline 76 & 2,000 & 51 & 1,000 & 53 & 1,333 & 58 & 1,500 & 64 & 1,500 & 47 & 1,444 & 47 & 1,458 & 50 \\
\hline 37 & 2,000 & 45 & 0,500 & 15 & 1,167 & 37 & 2,167 & 74 & 1,250 & 30 & 1,222 & 30 & 1,458 & 51 \\
\hline 32 & 2,013 & 54 & 1,750 & 71 & 1,167 & 49 & 1,000 & 29 & 1,881 & 65 & 1,643 & 57 & 1,482 & 52 \\
\hline 62 & 2,000 & 50 & 0,750 & 39 & 1,333 & 57 & 2,000 & 73 & 1,375 & 40 & 1,361 & 42 & 1,521 & 53 \\
\hline 06 & 2,000 & 39 & 1,250 & 57 & 1,833 & 71 & 1,000 & 41 & 1,625 & 55 & 1,694 & 58 & 1,521 & 54 \\
\hline 33 & 2,000 & 43 & 1,750 & 70 & 1,333 & 60 & 1,000 & 35 & 1,875 & 63 & 1,694 & 59 & 1,521 & 55 \\
\hline 95 & 2,333 & 62 & 1,750 & 73 & 1,000 & 29 & 1,000 & 17 & 2,042 & 69 & 1,694 & 60 & 1,521 & 56 \\
\hline 24 & 1,513 & 19 & 1,500 & 65 & 1,667 & 69 & 1,500 & 65 & 1,506 & 49 & 1,560 & 55 & 1,545 & 57 \\
\hline 58 & 2,333 & 57 & 0,750 & 42 & 2,167 & 75 & 1,167 & 50 & 1,542 & 52 & 1,750 & 63 & 1,604 & 58 \\
\hline 50 & 3,000 & 71 & 0,750 & 47 & 1,500 & 64 & 1,333 & 58 & 1,875 & 64 & 1,750 & 65 & 1,646 & 59 \\
\hline 90 & 3,333 & 79 & 1,250 & 62 & 1,000 & 26 & 1,000 & 15 & 2,292 & 74 & 1,861 & 69 & 1,646 & 60 \\
\hline 26 & 2,333 & 56 & 0,500 & 17 & 1,500 & 62 & 2,333 & 75 & 1,417 & 43 & 1,444 & 46 & 1,667 & 61 \\
\hline 72 & 2,333 & 59 & 1,750 & 72 & 1,500 & 66 & 1,333 & 59 & 2,042 & 70 & 1,861 & 68 & 1,729 & 62 \\
\hline 11 & 2,333 & 55 & 0,750 & 41 & 2,167 & 74 & 1,667 & 68 & 1,542 & 53 & 1,750 & 64 & 1,729 & 63 \\
\hline 39 & 2,667 & 66 & 1,750 & 74 & 1,500 & 67 & 1,000 & 39 & 2,208 & 72 & 1,972 & 70 & 1,729 & 64 \\
\hline 17 & 2,000 & 41 & 1,500 & 66 & 1,000 & 28 & 2,500 & 76 & 1,750 & 62 & 1,500 & 52 & 1,750 & 65 \\
\hline 84 & 3,000 & 74 & 1,000 & 54 & 1,167 & 47 & 1,833 & 71 & 2,000 & 68 & 1,722 & 62 & 1,750 & 66 \\
\hline 01 & 2,000 & 38 & 2,000 & 77 & 1,500 & 68 & 1,667 & 66 & 2,000 & 67 & 1,833 & 67 & 1,792 & 67 \\
\hline 89 & 3,667 & 84 & 1,500 & 67 & 1,025 & 32 & 1,000 & 20 & 2,583 & 78 & 2,064 & 72 & 1,798 & 68 \\
\hline 42 & 2,667 & 67 & 0,750 & 46 & 1,000 & 23 & 2,833 & 77 & 1,708 & 60 & 1,472 & 50 & 1,813 & 69 \\
\hline 93 & 3,000 & 76 & 1,250 & 60 & 1,167 & 48 & 2,000 & 72 & 2,125 & 71 & 1,806 & 66 & 1,854 & 70 \\
\hline 77 & 667 & 68 & 1,250 & 59 & 2,333 & 77 & 1,167 & 51 & 1,958 & 6 & 2,083 & 74 & 1,854 & 71 \\
\hline 92 & 3,475 & 80 & 1,000 & 55 & 2,000 & 73 & 1,000 & 42 & 2,238 & 73 & 2,158 & 75 & 1,869 & 72 \\
\hline 43 & 3,000 & 70 & 2,000 & 78 & 1,167 & 50 & 1,333 & 56 & 2,500 & 76 & 2,056 & 71 & 1,875 & 73 \\
\hline 96 & 2,667 & 69 & 2,750 & 82 & 1,333 & 61 & 1,000 & 36 & 2,708 & 79 & 2,250 & 77 & 1,938 & 74 \\
\hline 78 & 3,667 & 83 & 2,000 & 79 & 1,167 & 51 & 1,000 & 30 & 2,833 & 81 & 2,278 & 78 & 1,958 & 75 \\
\hline 52 & 1,667 & 30 & 1,000 & 51 & 2,500 & 78 & 3,000 & 79 & 1,333 & 33 & 1,722 & 61 & 2,042 & 76 \\
\hline 82 & 3,333 & 78 & 1,250 & 61 & 2,167 & 76 & 1,667 & 69 & 2,292 & 75 & 2,250 & 76 & 2,104 & 77 \\
\hline 41 & 4,000 & 86 & 1,500 & 68 & 1,833 & 72 & 1,667 & 67 & 2,750 & 80 & 2,444 & 80 & 2,250 & 78 \\
\hline 61 & 67 & 32 & 1,750 & 69 & 2,833 & 80 & 2,833 & 78 & 1,708 & 58 & 2,083 & 73 & 2,271 & 79 \\
\hline 63 & 1,667 & 33 & 1,250 & 56 & 4,333 & 84 & 4,167 & 83 & 1,458 & 45 & 2,417 & 79 & 2,854 & 80 \\
\hline 09 & & 82 & 3,000 & 86 & 2,667 & 79 & 4,333 & 84 & 3,333 & 85 & 3,111 & 81 & 3,417 & 81 \\
\hline 02 & 2,515 & 64 & 2,500 & 80 & 4,667 & 89 & 4,000 & 82 & 2,507 & 77 & 3,227 & 82 & 3,420 & 82 \\
\hline 54 & & 89 & 2,500 & 81 & 3,667 & 81 & 3,3 & 80 & 3,583 & 7 & 3,611 & 85 & 3,542 & 83 \\
\hline 74 & 000 & 72 & 2,750 & 83 & 4,500 & 85 & 4,667 & 87 & 2,875 & 82 & 3,417 & 83 & 3,729 & 84 \\
\hline 66 & 4,000 & 87 & 3,000 & 87 & 4,167 & 83 & 4,000 & 81 & 3,500 & 86 & 3,722 & 88 & 3,792 & 85 \\
\hline 14 & & 85 & 3,250 & 88 & 3,667 & 82 & 4,3 & 85 & 3,625 & 88 & 3,639 & 86 & 3,813 & 86 \\
\hline 40 & 3 & 77 & 3,000 & 84 & 4,500 & 86 & 5,000 & 88 & 3,167 & 83 & 3,611 & 84 & 3,958 & 87 \\
\hline 36 & 3,513 & 81 & 3,000 & 85 & 4,500 & 87 & 5,000 & 89 & 3,256 & 84 & 3,671 & 87 & 4,003 & 88 \\
\hline $1 !$ & 333 & 88 & 4,000 & 89 & 4,500 & 88 & 4,333 & 86 & 4,167 & 89 & 4,278 & 89 & 4,292 & 89 \\
\hline Teste & & & & & & & & & & & & & & \\
\hline & -0 & & 30 & & & & & & I, & & & & L & \\
\hline IAC-F-31 & 2,756 & & 1,400 & & 2,000 & & 1,50 & & $2,07 \varepsilon$ & & 2,052 & & 1,919 & \\
\hline IAS-5 & 1,479 & & 0,950 & & 1,000 & & 1,000 & & 1,215 & & 1,143 & & 1,148 & \\
\hline
\end{tabular}

Nota: As linhagens estão apresentadas em ordem crescente, baseada nas médias de quatro anos. As médias destacadas em negrito correspondem às $20 \%$ superiores em cada critério. 
Tabela 15. Médias das linhagens para o caráter dias para maturação (DM), em dias, para os quatro anos e para as combinações sucessivas dos anos.

\begin{tabular}{|c|c|c|c|c|c|c|c|c|c|c|c|c|c|c|}
\hline \multirow{2}{*}{ Linhagem } & \multicolumn{14}{|c|}{ Ano } \\
\hline & $1995 / 9$ & & $1996 / 9$ & & $1998 / 9$ & & $1999 / 0$ & & 1,2 & & 1,2 & & $1,2,3$, & \\
\hline 63 & 132,3 & 08 & 124,5 & 01 & 155,8 & 11 & 153,3 & 01 & 128,4 & 02 & 137,6 & 05 & 141,5 & \\
\hline 27 & 132,0 & 11 & 120,0 & 55 & 160,8 & 01 & 149,0 & 17 & 126,0 & 23 & 137,6 & 04 & 140,5 & \\
\hline 23 & 134,7 & 01 & 123,5 & 07 & 151,7 & 31 & 151,7 & 02 & 129,1 & 01 & 136,6 & 07 & 140,4 & \\
\hline 34 & 131,3 & 19 & 124,5 & 02 & 157,2 & 07 & 148,0 & 28 & 127,9 & 06 & 137,7 & 02 & 140,3 & \\
\hline 93 & 132,3 & 09 & 124,3 & 03 & 156,3 & 10 & 148,0 & 30 & 128,3 & 03 & 137,6 & 03 & 140,2 & \\
\hline 10 & 131,7 & 13 & 120,5 & 40 & 157,5 & 06 & 149,3 & 10 & 126,1 & 21 & 136,6 & 09 & 139,8 & \\
\hline 16 & 133,3 & 03 & 119,8 & 60 & 160,0 & 02 & 145,3 & 47 & 126,5 & 16 & 137,7 & 01 & 139,6 & \\
\hline 2 & 130,7 & 27 & 120,8 & 34 & 159,2 & 03 & 147,5 & 40 & 125,7 & 30 & 136,9 & 06 & 139,5 & \\
\hline 24 & 130,2 & 33 & 121,0 & 29 & 158,3 & 05 & 148,5 & 22 & 125,6 & 34 & 136,5 & 10 & 139,5 & \\
\hline 3 & 130,7 & 28 & 120,0 & 58 & 159,2 & 04 & 148,0 & 27 & 125,3 & 39 & 136,6 & 08 & 139,5 & \\
\hline 62 & 131,7 & 17 & 121,0 & 27 & 156,7 & 08 & 148,0 & 29 & 126,3 & 19 & 136,4 & 11 & 139,3 & \\
\hline 0 & 130,2 & 32 & 123,3 & 08 & 153,3 & 22 & 150,0 & 05 & 126,7 & 13 & 135,6 & 19 & 139,2 & \\
\hline 3 & 132,7 & 07 & 120,3 & 46 & 155,0 & 17 & 148,7 & 20 & 126,5 & 17 & 136,0 & 14 & 39,1 & \\
\hline 0 & 130,3 & 29 & 120,8 & 35 & 156,7 & 09 & 148,7 & 18 & 125,5 & 35 & 135,9 & 15 & 139,1 & \\
\hline 1 & 131,3 & 18 & 120,0 & 56 & 155,0 & 20 & 149,3 & 11 & 125,7 & 31 & 135,4 & 20 & 138,9 & \\
\hline 4 & 129,3 & 39 & 124,3 & 04 & 155,2 & 15 & 146,5 & 44 & 126,8 & 11 & 136,3 & 12 & 138,8 & \\
\hline 1 & 131,7 & 14 & 120,5 & 41 & 155,0 & 16 & 148,0 & 33 & 126,1 & 22 & 135,7 & 16 & 138,8 & \\
\hline 7 & 133,0 & 06 & 123,0 & 09 & 150,8 & 38 & 148,3 & 25 & 128,0 & 05 & 135,6 & 18 & 138,8 & \\
\hline 04 & 132,0 & 10 & 122,3 & 16 & 151,7 & 32 & 148,7 & 21 & 127,1 & 10 & 135,3 & 21 & 138,6 & \\
\hline & 129,7 & 37 & 122,3 & 18 & 153,3 & 23 & 149,3 & 12 & 126,0 & 25 & 135,1 & 22 & 138,6 & \\
\hline & 7 & 16 & 124,0 & 06 & 153,0 & 27 & 145,8 & 46 & 127,8 & 07 & 2 & 13 & 138,6 & \\
\hline 9 & 29,3 & 41 & 121,3 & 26 & 152,5 & 29 & 150,8 & 03 & 125,3 & 40 & 134,4 & 36 & 138,5 & \\
\hline 5 & 130,0 & 36 & 120,3 & 49 & 155,0 & 18 & 148,3 & 23 & 125,1 & 42 & 135,1 & 23 & 138,4 & \\
\hline & 9,7 & 38 & 122,8 & 13 & 150,8 & 41 & 150,2 & 04 & 126,2 & 20 & 134,4 & 35 & 138,4 & \\
\hline 5 & 131,3 & 20 & 122,3 & 17 & 150,0 & 47 & 149,7 & 09 & 126,8 & 12 & 134,5 & 33 & 138,3 & \\
\hline & 3 & 21 & 120,0 & 57 & & 30 & & 15 & 125,7 & 32 & & 32 & 138,3 & \\
\hline 9 & 28,3 & 52 & 120,3 & 52 & 155,8 & 12 & 148,7 & 19 & 124,3 & 53 & 134,8 & 28 & 138,3 & \\
\hline 0 & 129,2 & 42 & 124,3 & 05 & 150,8 & 37 & 148,3 & 24 & 126,7 & 14 & 134,8 & 29 & 138,1 & \\
\hline & 9,3 & 40 & 12 & 50 & 15 & 19 & & 34 & 124,8 & 17 & & 27 & 138,1 & \\
\hline 7 & 130,3 & 30 & 121,3 & 24 & 153,3 & 25 & 147,5 & 41 & 125,8 & 7 & 135,0 & 25 & 138,1 & \\
\hline 1 & 127,3 & 63 & 122,3 & 19 & & 24 & & 13 & 124,8 & 4 & & 39 & 138,1 & \\
\hline 3 & 134,2 & 02 & 122,3 & 15 & 147,5 & 58 & 148,2 & 26 & 128,2 & 0 & 134,7 & 30 & 138,0 & \\
\hline 4 & 9,0 & 43 & 122,5 & 14 & 8 & 42 & 14 & 08 & 125,8 & 29 & 134,1 & 42 & 138,0 & \\
\hline & & 5 & & 44 & & 14 & & 32 & & & & & 8,0 & \\
\hline 2 & 131,0 & 24 & 120,8 & 33 & 15 & 33 & 148,0 & 35 & 125,9 & 2 &, 5 & 34 & 137,9 & \\
\hline 0 & & 54 & 123,0 & 10 & & 39 & & 16 & & 3 & & 43 & 137,8 & \\
\hline 9 & 1320 & 12 & 120,8 & 32 & 150,0 & 50 & 14 & 38 & 126,4 & 1 & 13 & 10 & 137,7 & \\
\hline 8 & 127,0 & 65 & 121,0 & 31 & 153,3 & 26 & 149,3 & 14 & 124,0 & 57 & 133,8 & 46 & 137,7 & \\
\hline 20 & & 15 & 122,8 & 12 & & 28 & & $-\pi$ & 127,2 & & & 17 & 137,6 & \\
\hline 6 & 6,0 & $6 \varepsilon$ & 120,0 & 5 & 15 & 13 & & 3 & 123,0 & & & 44 & 137,5 & \\
\hline 76 & 130,3 & 31 & 121,3 & 25 & & 36 & & 4 & 125,8 & & & 41 & 137,3 & \\
\hline 0 & 131,0 & 23 & 120,3 & 47 & & 3 & & 4 & 125,6 & & & 38 & 137,1 & \\
\hline 4 & 128,3 & 49 & 120,8 & 37 & 150,8 & 44 & 148,0 & 37 & 124,5 & 5 & 133,3 & 49 & 137,0 & \\
\hline 3 & 127,7 & 57 & 122,0 & 20 & 15 & 48 & 146,7 & 4 & 124,8 & 46 & 15 & 50 & 13 & \\
\hline 5 & & 6 & 12 & 1 & & 40 & 144,3 & 5 & 125,3 & & 3,8 & 45 & , & \\
\hline 0 & 28,3 & $4 \varepsilon$ & 120,8 & 36 & 151,7 & 34 & 145,0 & 49 & 124,5 & 5 & 3,6 & $4 \varepsilon$ & 136,4 & \\
\hline & & כ1 & & & & 5 & & 42 & & 56 & & 55 & & \\
\hline
\end{tabular}


Tabela 15. Médias das linhagens para o caráter dias para maturação (DM), em dias, para os quatro anos e para as combinações sucessivas dos anos.

\begin{tabular}{|c|c|c|c|c|c|c|c|c|c|c|c|c|c|c|}
\hline \multirow{2}{*}{ Linhagem } & \multicolumn{14}{|c|}{ Ano } \\
\hline & \multicolumn{2}{|c|}{$1995 / 96(1)$} & \multicolumn{2}{|c|}{$\begin{array}{l}1996 / 97(2) \\
\end{array}$} & \multicolumn{2}{|c|}{ 1998/99(3) } & \multicolumn{2}{|c|}{ 1999/00(4) } & \multicolumn{2}{|l|}{1,2} & \multicolumn{2}{|c|}{$1,2,3$} & \multicolumn{2}{|c|}{$1,2,3,4$} \\
\hline 03 & 131,0 & 22 & 121,0 & 28 & 149,2 & 54 & 144,0 & 53 & 126,0 & 24 & 133,7 & 47 & 136,3 & 48 \\
\hline 85 & 133,3 & 04 & 120,0 & 54 & 149,7 & 53 & 141,7 & 56 & 126,7 & 15 & 134,3 & 37 & 136,2 & 49 \\
\hline 25 & 124,2 & 79 & 121,5 & 23 & 150,8 & 43 & 148,0 & 36 & 122,8 & 65 & 132,2 & 58 & 136,1 & 50 \\
\hline 58 & 131,0 & 25 & 118,8 & 68 & 149,2 & 55 & 144,2 & 52 & 124,9 & 44 & 133,0 & 51 & 135,8 & 51 \\
\hline 64 & 133,0 & 05 & 121,8 & 21 & 150,0 & 49 & 138,3 & 64 & 127,4 & 08 & 134,9 & 26 & 135,8 & 52 \\
\hline 91 & 126.0 & 70 & 120.3 & 53 & 146.7 & 61 & 150.0 & 06 & 1231 & 63 & 1310 & 61 & 135.7 & 53 \\
\hline 11 & 130,7 & 26 & 120,3 & 48 & 154,2 & 21 & 137,5 & 66 & 125,5 & 37 & 135,0 & 24 & 135,6 & 54 \\
\hline 01 & 130,0 & 34 & 119,8 & 61 & 148,3 & 57 & 144,3 & 51 & 124,9 & 45 & 132,7 & 54 & 135,6 & 55 \\
\hline 55 & 125,3 & 73 & 119,0 & 66 & 145,8 & 65 & 150,0 & 07 & 122,2 & 71 & 130,1 & 68 & 135,0 & 56 \\
\hline 46 & 130,0 & 35 & 120,5 & 42 & 146,7 & 59 & 141,7 & 57 & 125,3 & 41 & 132,4 & 57 & 134,7 & 57 \\
\hline 82 & 127,0 & 64 & 120,8 & 38 & 150,8 & 45 & 140,0 & 58 & 123,9 & 58 & 132,9 & 52 & 134,6 & 58 \\
\hline 61 & 127,7 & 62 & 120,5 & 45 & 150,0 & 51 & 140,0 & 59 & 124,1 & 55 & 132,7 & 53 & 134,5 & 59 \\
\hline 81 & 125,7 & 71 & 120,8 & 39 & 150,8 & 46 & 138,7 & 63 & 123,2 & 62 & 132,4 & 56 & 134,0 & 60 \\
\hline 28 & 128,7 & 45 & 120,5 & 43 & 146,7 & 60 & 140,0 & 60 & 124,6 & 49 & 131,9 & 59 & 134,0 & 61 \\
\hline 17 & 125,3 & 72 & 117,5 & 74 & 145,0 & 69 & 147,7 & 39 & 121,4 & 78 & 129,3 & 70 & 133,9 & 62 \\
\hline 49 & 128,3 & 50 & 116,8 & 78 & 146,7 & 64 & 143,3 & 55 & 122,5 & 66 & 130,6 & 65 & 133,8 & 63 \\
\hline 71 & 129,0 & 44 & 121,0 & 30 & 140,8 & 74 & 140,0 & 61 & 125,0 & 43 & 130,3 & 67 & 132,7 & 64 \\
\hline 87 & 127,0 & 66 & 116,5 & 81 & 149,2 & 56 & 137,7 & 65 & 121,8 & 74 & 130,9 & 62 & 132,6 & 65 \\
\hline 39 & 127,7 & 59 & 117,3 & 76 & 146,7 & 63 & 137,5 & 67 & 122,5 & 67 & 130,5 & 66 & 132,3 & 66 \\
\hline 57 & 127,7 & 61 & 119,5 & 64 & 145,0 & 67 & 136,7 & 69 & 123,6 & 61 & 130,7 & 64 & 132,2 & 67 \\
\hline 86 & 128,7 & 47 & 119,0 & 65 & 146,7 & 62 & 133,3 & 76 & 123,8 & 59 & 131,4 & 60 & 131,9 & 68 \\
\hline 69 & 128,7 & 46 & 120,3 & 51 & 143,3 & 71 & 135,0 & 71 & 124,5 & 52 & 130,8 & 63 & 131,8 & 69 \\
\hline 77 & 128,0 & 56 & 115,8 & 83 & 141,7 & 73 & 139,8 & 62 & 121,9 & 73 & 128,5 & 71 & 131,3 & 70 \\
\hline 89 & 125,0 & 75 & 118,0 & 71 & 145,0 & 68 & 133,3 & 77 & 121,5 & 76 & 129,3 & 69 & 130,3 & 71 \\
\hline 12 & 128,0 & 53 & 116,8 & 79 & 139,2 & 76 & 135,0 & 72 & 122,4 & 68 & 128,0 & 73 & 129,7 & 72 \\
\hline 21 & 126,0 & 67 & 117,5 & 73 & 141,7 & 72 & 133,3 & 78 & 121,8 & 75 & 128,4 & 72 & 129,6 & 73 \\
\hline 32 & 124,7 & 76 & 118,3 & 69 & 140,8 & 75 & 130,0 & 83 & 121,5 & 77 & 127,9 & 74 & 128,4 & 74 \\
\hline 90 & 120,0 & 87 & 117,5 & 75 & & 66 & 129,2 & 86 & 118,8 & 84 & 127,8 & 75 & 128,1 & 76 \\
\hline 68 & 126,0 & 69 & 121,5 & 22 & 130,0 & 84 & 135,0 & 73 & 123,8 & 60 & 125,8 & 78 & 128,1 & 75 \\
\hline 43 & 120.7 & 84 & 115.0 & 84 & 138,3 & 77 & 137.5 & 68 & 117.8 & 85 & 124.7 & 84 & 127.9 & 77 \\
\hline 92 & 125,2 & 74 & 119,0 & 67 & 130,0 & 86 & 135,8 & 70 & 122,1 & 72 & 124,7 & 83 & 127,5 & 78 \\
\hline 73 & 122,0 & 82 & 116,0 & 82 & 136,7 & 78 & 134,2 & 74 & 119,0 & 83 & 124,9 & 81 & 127,2 & 79 \\
\hline 70 & 128,0 & 55 & 116,5 & 80 & 133,3 & 81 & 130,8 & 82 & 122,3 & 69 & 125,9 & 77 & 127,2 & 80 \\
\hline 83 & 123,0 & 81 & 118,3 & 70 & 134,2 & 80 & 131,7 & 81 & 120,6 & 79 & 125,1 & 80 & 126,8 & 81 \\
\hline 80 & 124,7 & 77 & 119,8 & 63 & 130,0 & 85 & 132,5 & 79 & 122,2 & 70 & 124,8 & 82 & 126,7 & 82 \\
\hline 47 & 123.3 & 80 & 117.0 & 77 & & 79 & 130.0 & 84 & 120.2 & & 125,4 & 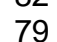 & 126.5 & oc \\
\hline 51 & 121,3 & 83 & 113,5 & 87 & 145,0 & 70 & 125,0 & 89 & 117,4 & 86 & 126,6 & 76 & 126,2 & 84 \\
\hline 18 & 124,3 & 78 & 114,0 & 85 & 130,0 & 87 & 134,2 & 75 & 119,2 & 82 & 122,8 & 86 & 125,6 & 85 \\
\hline 99 & 120,7 & 85 & 117,8 & 72 & 131,7 & 82 & 129,2 & 87 & 119,2 & 81 & 123,4 & 85 & 124,8 & 86 \\
\hline 95 & 120,0 & 88 & 114,0 & 86 & 130,0 & 88 & 132,5 & 80 & 117,0 & 87 & 121,3 & 88 & 124,1 & 87 \\
\hline 96 & 120,0 & 89 & 113,3 & 88 & 130,8 & 83 & 130,0 & 85 & 116.6 & 88 & 121,4 & 87 & 123,5 & 88 \\
\hline 53 & 120,0 & 86 & 110,8 & 89 & 130,0 & 89 & 125,8 & 88 & 115,4 & 89 & 120,3 & 89 & 121,6 & 89 \\
\hline & & & & & & & & & & & & & & \\
\hline & 129,4 & & 122,5 & & 13 & & 138,1 & & 126,0 & & 129,0 & & 13 & \\
\hline IAC-I & 122,4 & & 120 & & 131,2 & & 130,8 & & 121,4 & & 124,6 & & & \\
\hline 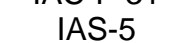 & 120,8 & & 115,4 & & 125,0 & & 125,0 & & 118,1 & & 120,4 & & 121,2 & \\
\hline
\end{tabular}

Nota: As linhagens estão apresentadas em ordem decrescente, baseada nas médias de quatro anos. As médias destacadas em negrito correspondem às $20 \%$ superiores em cada critério. 
Tabela 16. Médias das linhagens para o caráter produção de grãos (PG), em g/parcela, para os quatro anos e para as combinações sucessivas dos anos.

\begin{tabular}{|c|c|c|c|c|c|c|c|c|c|c|c|c|c|c|}
\hline \multirow{2}{*}{ Linhagem } & \multicolumn{14}{|c|}{ Ano } \\
\hline & 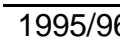 & & $1996 / 9$ & & $1998 / 9$ & & $1999 / 0$ & & 1,2 & & 1,2 & & $1,2,3$, & \\
\hline 23 & 227,0 & 36 & 342,5 & 04 & 546,2 & 06 & 369,0 & 02 & 284,8 & 15 & 371,9 & 02 & 371,2 & 01 \\
\hline 41 & 253,0 & 22 & 269,0 & 44 & 573,7 & 04 & 338,5 & 06 & 261,0 & 26 & 365,2 & 04 & 358,5 & 02 \\
\hline 84 & 229,3 & 34 & 253,5 & 55 & 603,3 & 01 & 342,5 & 05 & 241,4 & 38 & 362,1 & 07 & 357,2 & 03 \\
\hline 13 & 358,7 & 03 & 340,0 & 06 & 371,5 & 32 & 337,3 & 07 & 349,3 & 03 & 356,7 & 09 & 351,9 & 04 \\
\hline 72 & 271,3 & 13 & 208,0 & 78 & 578,5 & 02 & 333,2 & 12 & 239,7 & 41 & 352,6 & 10 & 347,8 & 05 \\
\hline 10 & 286,3 & 10 & 301,5 & 24 & 504,3 & 10 & 284,7 & 18 & 293,9 & 11 & 364,1 & 05 & 344,2 & 06 \\
\hline 24 & 276,0 & 12 & 233,0 & 67 & 574,3 & 03 & 290,0 & 16 & 254,5 & 31 & 361,1 & 08 & 343,3 & 07 \\
\hline 76 & 227,0 & 37 & 254,0 & 54 & 551,0 & 05 & 335,0 & 10 & 240,5 & 40 & 344,0 & 12 & 341,8 & 08 \\
\hline 33 & 194,3 & 48 & 274,5 & 37 & 530,5 & 07 & 363,0 & 03 & 234,4 & 43 & 333,1 & 15 & 340,6 & 09 \\
\hline 05 & 358,3 & 04 & 358,5 & 02 & 420,8 & 16 & 213,0 & 50 & 358,4 & 02 & 379,2 & 01 & 337,7 & 10 \\
\hline 93 & 253,7 & 21 & 260,0 & 50 & 505,3 & 09 & 312,7 & 13 & 256,8 & 29 & 339,7 & 14 & 332,9 & 11 \\
\hline 19 & 369,7 & 02 & 318,0 & 15 & 361,8 & 36 & 271,8 & 23 & 343,8 & 04 & 349,8 & 11 & 330,3 & 12 \\
\hline 63 & 435,7 & 01 & 320,5 & 12 & 347,8 & 37 & 215,5 & 48 & 378,1 & 01 & 368,0 & 03 & 329,9 & 13 \\
\hline 04 & 314,7 & 07 & 314,0 & 18 & 458,0 & 12 & 228,8 & 42 & 314,3 & 08 & 362,2 & 06 & 328,9 & 14 \\
\hline 67 & 202,3 & 43 & 312,5 & 19 & 444,0 & 13 & 335,8 & 09 & 257,4 & 28 & 319,6 & 21 & 323,7 & 15 \\
\hline 50 & 242,0 & 28 & 220,0 & 73 & 486,2 & 11 & 346,0 & 04 & 231,0 & 47 & 316,1 & 24 & 323,5 & 16 \\
\hline 34 & 291,7 & 09 & 278,0 & 32 & 375,0 & 30 & 337,2 & 08 & 284,8 & 14 & 314,9 & 25 & 320,5 & 17 \\
\hline 60 & 258,0 & 20 & 274,0 & 38 & 430,2 & 14 & 300,7 & 15 & 266,0 & 24 & 320,7 & 19 & 315,7 & 18 \\
\hline 62 & 315,0 & 06 & 340,5 & 05 & 371,0 & 33 & 223,0 & 43 & 327,8 & 06 & 342,2 & 13 & 312,4 & 19 \\
\hline 25 & 208,5 & 41 & 236,5 & 64 & 516,8 & 08 & 285,7 & 17 & 222,5 & 56 & 320.6 & 20 & 311,9 & 20 \\
\hline 16 & 280,0 & 11 & 256,0 & 52 & 421,5 & 15 & 263,2 & 26 & 268,0 & 20 & 319,2 & 22 & 305,2 & 21 \\
\hline 48 & 263,7 & 18 & 317,5 & 16 & 382,5 & 28 & 250,5 & 32 & 290,6 & 12 & 321,2 & 18 & 303,5 & 22 \\
\hline 06 & 346,7 & 05 & 321,5 & 10 & 256,8 & 72 & 279,0 & 21 & 334,1 & 05 & 308,3 & 27 & 301,0 & 23 \\
\hline 86 & 268,0 & 14 & 291,0 & 27 & 420,2 & 17 & 216,3 & 47 & 279,5 & 18 & 326,4 & 17 & 298,9 & 24 \\
\hline 46 & 267,3 & 15 & 321,0 & 11 & 403,0 & 22 & 202,7 & 55 & 294,2 & 10 & 330,4 & 16 & 298,5 & 25 \\
\hline 0 & 250,0 & 24 & 317,0 & 17 & 388,0 & 24 & 233,7 & 38 & 283,5 & 17 & 318,3 & 23 & 297,2 & 26 \\
\hline 57 & 178,7 & 56 & 334,0 & 07 & 410,0 & 20 & 255,3 & 28 & 256,3 & 30 & 307.6 & 28 & 294,5 & 27 \\
\hline 38 & 226.3 & 38 & 257,2 & 51 & 406,3 & 21 & 281,2 & 20 & 241.8 & 37 & 296.6 & 33 & 292,8 & 28 \\
\hline 61 & 190,7 & 50 & 270,5 & 43 & 322,0 & 48 & 384,2 & 01 & 230,6 & 48 & 261,1 & 50 & 291,8 & 29 \\
\hline 12 & 195,0 & 46 & 305,0 & 22 & 385,0 & 25 & 271,2 & 24 & 250,0 & 33 & 295,0 & 35 & 289,0 & 30 \\
\hline 53 & 238,7 & 30 & 254,5 & 53 & 322,5 & 47 & 334,7 & 11 & 246,6 & 34 & 271,9 & 45 & 287,6 & 31 \\
\hline 94 & 309,3 & 08 & 282,5 & 29 & 303,0 & 57 & 238,7 & 35 & 295,9 & 09 & 298,3 & 32 & 283,4 & 32 \\
\hline 59 & 248,0 & 25 & 320,5 & 13 & 345,3 & 38 & 218,2 & 45 & 284,3 & 16 & 304,6 & 30 & 283,0 & 33 \\
\hline 27 & 266,7 & 16 & 305,0 & 21 & 334,7 & 42 & 211,3 & 51 & 285,8 & 13 & 302,1 & 31 & 279,4 & 34 \\
\hline 08 & 185,3 & 54 & 331,0 & 08 & 370,2 & 34 & 230,2 & 40 & 258,2 & 27 & 295,5 & 34 & 279,2 & 35 \\
\hline 69 & 240,0 & 29 & 390,0 & 01 & 301,5 & 59 & 182,2 & 62 & 315,0 & 07 & 310,5 & 26 & 278,4 & 36 \\
\hline 1 & 176,7 & 59 & 309,5 & 20 & 343,2 & 39 & 283,3 & 19 & 243,1 & 35 & 276,4 & 42 & 278,2 & 37 \\
\hline 52 & 219,7 & 39 & 245,5 & 58 & 385,0 & 26 & 255,1 & 30 & 232,6 & 46 & 283,4 & 38 & 276,3 & 38 \\
\hline 58 & 125,0 & 78 & 323,0 & 09 & 415,3 & 18 & 219,9 & 44 & 224,0 & 54 & 287,8 & 36 & 270,8 & 39 \\
\hline 03 & 188,7 & 51 & 343,5 & 03 & 383,8 & 27 & 163,3 & 69 & 266,1 & 23 & 305,3 & 29 & 269,8 & 40 \\
\hline 51 & 233,3 & 31 & 272,0 & 40 & 318,7 & 52 & 255,2 & 29 & 252,7 & 32 & 274,7 & 43 & 269,8 & 41 \\
\hline 98 & 169,7 & 64 & 265,0 & 48 & 414,0 & 19 & 218,0 & 46 & 217,3 & 60 & 282,9 & 39 & 266,7 & 42 \\
\hline 89 & 177,7 & 57 & 267,5 & 45 & 303,3 & 56 & 312,5 & 14 & 222,6 & 55 & 249,5 & 59 & 265,3 & 43 \\
\hline 91 & 177,3 & 58 & 266,5 & 47 & 374,2 & 31 & 231,3 & 39 & 221,9 & 57 & 272,7 & 44 & 262,3 & 44 \\
\hline 37 & 264,0 & 17 & 278,0 & 33 & 301,8 & 58 & 195,7 & 56 & 271,0 & 19 & 281,3 & 41 & 259,9 & 45 \\
\hline 30 & 212,0 & 40 & 273,0 & 39 & 367,2 & 35 & 179,2 & 63 & 242,5 & 36 & 284,1 & 37 & 257,8 & 46 \\
\hline & & 49 & & & & & & 36 & & & 261,8 & & 255 & 47 \\
\hline
\end{tabular}


Tabela 16. Médias das linhagens para o caráter produção de grãos (PG), em g/parcela, para os quatro anos e para as combinações sucessivas dos anos.

\begin{tabular}{|c|c|c|c|c|c|c|c|c|c|c|c|c|c|c|}
\hline \multirow{2}{*}{ Linhagem } & \multicolumn{14}{|c|}{ Ano } \\
\hline & \multicolumn{2}{|c|}{$1995 / 96(1)$} & \multicolumn{2}{|c|}{$\begin{array}{l}1996 / 97(2) \\
\end{array}$} & \multicolumn{2}{|c|}{ 1998/99(3) } & \multicolumn{2}{|c|}{ 1999/00(4) } & \multicolumn{2}{|l|}{1,2} & \multicolumn{2}{|c|}{$1,2,3$} & \multicolumn{2}{|c|}{$1,2,3,4$} \\
\hline 32 & 170,0 & 63 & 278,0 & 34 & 319,5 & 50 & 254,3 & 31 & 224,0 & 53 & 255,8 & 54 & 255,5 & 48 \\
\hline 01 & 228,7 & 35 & 223,5 & 71 & 323,1 & 46 & 239,7 & 34 & 226,1 & 52 & 258,4 & 51 & 253,7 & 50 \\
\hline 18 & 231,7 & 32 & 235,0 & 65 & 289,3 & 64 & 257,5 & 27 & 233,3 & 45 & 252,0 & 57 & 253,4 & 49 \\
\hline 20 & 153,0 & 71 & 278,5 & 31 & 342,8 & 40 & 236,5 & 37 & 215,8 & 62 & 258,1 & 52 & 252,7 & 51 \\
\hline 26 & 244,3 & 27 & 288,0 & 28 & 311,8 & 54 & 163,3 & 70 & 266,2 & 22 & 281,4 & 40 & 251,9 & 52 \\
\hline 28 & 258,3 & 19 & 267,0 & 46 & 271,2 & 68 & 195,0 & 57 & 262,7 & 25 & 265,5 & 46 & 247,9 & 53 \\
\hline 82 & 162,3 & 68 & 293,0 & 26 & 318,8 & 51 & 204,0 & 54 & 227,7 & 51 & 258,1 & 53 & 244,5 & 54 \\
\hline 97 & 169,3 & 65 & 244,5 & 59 & 375,8 & 29 & 188,2 & 59 & 206,9 & 67 & 263,2 & 47 & 244,5 & 55 \\
\hline 92 & 181,1 & 55 & 275,0 & 35 & 240,8 & 78 & 278,0 & 22 & 228,0 & 50 & 232,3 & 65 & 243,7 & 56 \\
\hline 42 & 206,3 & 42 & 192,5 & 82 & 339,0 & 41 & 229,2 & 41 & 199,4 & 69 & 245,9 & 60 & 241,8 & 57 \\
\hline 21 & 251,7 & 23 & 222,5 & 72 & 258,5 & 71 & 205,3 & 52 & 237,1 & 42 & 244,2 & 61 & 234,5 & 58 \\
\hline 77 & 145,7 & 73 & 271,0 & 42 & 273,5 & 67 & 243,7 & 33 & 208,3 & 66 & 230,1 & 66 & 233,5 & 59 \\
\hline 64 & 230,0 & 33 & 304,5 & 23 & 227,0 & 82 & 166,7 & 67 & 267,3 & 21 & 253,8 & 55 & 232,0 & 60 \\
\hline 68 & 162,7 & 66 & 293,5 & 25 & 293,3 & 62 & 178,0 & 65 & 228,1 & 49 & 249,8 & 58 & 231,9 & 61 \\
\hline 87 & 247,7 & 26 & 234,0 & 66 & 306,2 & 55 & 125,0 & 81 & 240,8 & 39 & 262,6 & 48 & 228,2 & 62 \\
\hline 81 & 187,0 & 53 & 230,0 & 68 & 288,2 & 65 & 204,3 & 53 & 208,5 & 65 & 235,1 & 64 & 227,4 & 63 \\
\hline 74 & 175,7 & 60 & 182,0 & 87 & 325,8 & 45 & 215,3 & 49 & 178,8 & 76 & 227,8 & 68 & 224,7 & 64 \\
\hline 85 & 148,7 & 72 & 319,5 & 14 & 292,7 & 63 & 136,8 & 77 & 234,1 & 44 & 253,6 & 56 & 224,4 & 65 \\
\hline 02 & 132,9 & 75 & 224,0 & 70 & 274,0 & 66 & 264,5 & 25 & 178,4 & 77 & 210,3 & 74 & 223,8 & 66 \\
\hline 31 & 172,5 & 61 & 218,0 & 76 & 328,5 & 44 & 153,3 & 73 & 195,3 & 72 & 239,7 & 62 & 218,1 & 67 \\
\hline 5 & 188,3 & 52 & 209,0 & 77 & 319,8 & 49 & 151,2 & 75 & 198,7 & 70 & 239,1 & 63 & 217,1 & 68 \\
\hline 39 & 195,7 & 45 & 237,5 & 63 & 243,3 & 75 & 167,0 & 66 & 216,6 & 61 & 225,5 & 72 & 210,9 & 69 \\
\hline 96 & 105,0 & 83 & 243,5 & 60 & 329,8 & 43 & 152,3 & 74 & 174,3 & 80 & 226,1 & 71 & 207,7 & 70 \\
\hline 83 & 113,3 & 81 & 262,0 & 49 & 314,8 & 53 & 113,1 & 85 & 187,7 & 75 & 230,1 & 67 & 200,8 & 71 \\
\hline 17 & 156,3 & 70 & 275,0 & 36 & 250,2 & 73 & 118,0 & 83 & 215,7 & 63 & 227,2 & 69 & 199,9 & 72 \\
\hline 73 & 160,0 & 69 & 278,5 & 30 & 242,0 & 76 & 116,0 & 84 & 219,3 & 58 & 226,8 & 70 & 199,1 & 74 \\
\hline 47 & 194,7 & 47 & 240,5 & 61 & 229,5 & 79 & 131,0 & 78 & 217,6 & 59 & 221,6 & 73 & 198,9 & 73 \\
\hline 70 & 170,7 & 62 & 252,0 & 56 & 204,5 & 83 & 139,8 & 76 & 211,3 & 64 & 209,1 & 76 & 191,7 & 75 \\
\hline 71 & 141,7 & 74 & 203,0 & 80 & 261,0 & 70 & 156,2 & 72 & 172,3 & 81 & 201,9 & 78 & 190,5 & 76 \\
\hline 99 & 104.0 & 84 & 249.0 & 57 & 228,3 & 80 & 162,0 & 71 & 176.5 & 78 & 193.8 & 79 & 185.8 & 77 \\
\hline 54 & & 82 & 239,5 & 62 & 264,8 & 69 & 125,7 & 80 & 175,4 & 79 & 205,2 & 77 & 185,3 & 78 \\
\hline 49 & 124,3 & 79 & 179,0 & 88 & 244,8 & 74 & 188,2 & 60 & 151,7 & 86 & 182,7 & 83 & 184,1 & 79 \\
\hline 43 & 98,0 & 86 & 218,5 & 75 & 227,2 & 81 & 192,0 & 58 & 158,3 & 84 & 181,2 & 84 & 183,9 & 81 \\
\hline 80 & 202,0 & 44 & 185,6 & 85 & 241,3 & 77 & 104,7 & 86 & 193,8 & 73 & 209,6 & 75 & 183,4 & 80 \\
\hline 90 & 96,0 & 87 & 156,5 & 89 & 299,2 & 60 & 163,5 & 68 & 126,3 & 89 & 183,9 & 81 & 178,8 & 82 \\
\hline 09 & 162,4 & 67 & 229,5 & 69 & 175,3 & 86 & 128,8 & 79 & 195,9 & 71 & & 80 & 174,0 & 83 \\
\hline 15 & 102,3 & 85 & 220,0 & 74 & 183,2 & 84 & 182,8 & 61 & 161,2 & 83 & 168,5 & 85 & 172,1 & 84 \\
\hline 95 & 128,3 & 76 & 187,0 & 84 & 181,5 & 85 & 179,2 & 64 & 157,7 & 8 & 165,6 & 86 & 169,0 & 85 \\
\hline 14 & 70,7 & 89 & 185,0 & 86 & 295,7 & 61 & 75,3 & 88 & 127,8 & 88 & 183,8 & 82 & 156,7 & 86 \\
\hline 40 & 127,0 & 77 & 272,0 & 41 & 72,4 & 89 & 123,3 & 82 & 199,5 & 68 & 157,1 & 88 & 148,7 & 87 \\
\hline 36 & 124,0 & 80 & 204,5 & 79 & 161,7 & 87 & 68,7 & 89 & 164,3 & 8 & 163,4 & 87 & 139,7 & 88 \\
\hline 66 & 91,0 & 88 & 189,5 & 83 & 105,8 & 88 & 103,3 & 87 & 140,3 & 87 & 128,8 & 89 & 122,4 & 89 \\
\hline & & & & & & & & & & & & & & \\
\hline & 275,7 & & 320,1 & & 419,9 & & 316 & & 297,9 & & 338 & & 327 & \\
\hline IAC- & 242,2 & & 34 & & 480,0 & & 380,8 & & 29 & & & & 367,5 & \\
\hline D & 253,2 & & 315,7 & & 375,9 & & 279,9 & & 284,5 & & 314,9 & & 297,1 & \\
\hline
\end{tabular}

Nota: As linhagens estão apresentadas em ordem decrescente, baseada nas médias de quatro anos. As médias destacadas em negrito correspondem às $20 \%$ superiores em cada critério. 


\section{REFERÊNCIAS BIBLIOGRÁFICAS}

AKHTER, M.; SNELLER, C.H. Genotype x planting date interaction and selection of early maturing soybean genotypes. Crop Science, v.36, n.4, p.883-889, 1996.

ALLARD, R.W. Princípios de melhoramento genético das plantas. São Paulo: Edgar Blucer, 1971. 381p.

ALLIPRANDINI, L.F.; TOLEDO, J.F.F de; FONSECA JUNIOR, N.S.; KIIHL, R.A.S.; ALMEIDA, L.A. de. Ganho genético em soja no Estado do Paraná, via melhoramento, no período de 1985/86 a 1989/90. Pesquisa Agropecuária Brasileira, v.28, n.4, p.489-497, 1993.

AZEVEDO, V.H. Herança da resistência da soja ao Diaporthe phaseolorum f.sp. meridionalis e eficiência na seleção de caracteres agronômicos. Viçosa, 2000. 102p. Dissertação (M.S.) Universidade Federal de Viçosa.

AZEVEDO FILHO, J.A. de; VELLO, N.A.; GOMES, R.L.F. Estimativas de parâmetros genéticos de populações de soja em solos contrastantes na saturação de alumínio. Bragantia, v.57, n.2., p.227-239, 1998.

BACKES, R.L. Estimativas de parâmetros genéticos , correção do efeito ambiental e predição de ganhos por seleção em populações $F_{5}$ e $F_{6}$ de soja (Glycine max (L.) Merrill). Viçosa, 2000. 77p. Dissertação (M.S.) - Universidade Federal de Viçosa.

BARBIN, D. Componentes de variância. Piracicaba: Escola Superior de Agricultura "Luiz de Queiroz", Departamento de Matemática e Estatística, 1993. 108p.

BOARD, J.E.; KANG, M.S.; HARVILLE, B.G. Path analysis identify indirect selection criteria for yield of late-planted soybean. Crop Science, v.37, n.3, p.879-885, 1997. 
BORÉM, A. Melhoramento de Plantas. 2.ed. Viçosa: Editora UFV, 1998. 453p.

BURTON, J.W. Quantitative genetics: results relevant to soybean breeding. In: WILCOX, J.R. (ed.) Soybeans: improvement, production and uses. 2.ed. Madison: ASA, 1987. p.211247. (Agronomy. A. ser. of Monographs, 16)

CHAVES, L.J.; VENCOVSKY, R.; GERALDI, I.O. Modelo não linear aplicado ao estudo da interação de genótipo x ambientes em milho. Pesquisa Agropecuária Brasileira, v.24, n.2, p.259-269, 1989.

CRUZ, C.D.; REGAZZI, A.J. Modelos biométricos aplicados ao melhoramento genético. Viçosa: UFV, Imprensa Universitária, 1994. Cap.1, p.1-34: Interação genótipos x ambientes.

CRUZ, C.D.; REGAZZI, A.J. Modelos biométricos aplicados ao melhoramento genético. Viçosa: UFV, Imprensa Universitária, 1994. Cap.2, p.35-70: Estabilidade e adaptabilidade.

CRUZ, C.D.; REGAZZI, A.J. Modelos biométricos aplicados ao melhoramento genético. Viçosa: UFV, Imprensa Universitária, 1994. Cap.3, p.73-101: Correlações genotípica, fenotípica e de ambiente.

CRUZ, C.D.; REGAZZI, A.J. Modelos biométricos aplicados ao melhoramento genético. Viçosa: UFV, Imprensa Universitária, 1994. Cap.4, p.103-129: Ganhos por seleção.

DESTRO, D.; SEDIYAMA, T.; SILVA, J.C.; SEDIYAMA, C.S.; THIÉBAUT, J.T.L. Estimativas de herdabilidade de alguns caracteres, em dois cruzamentos de soja. Pesquisa Agropecuária Brasileira, v.22, n.3, p.291-304, 1987.

FALCONER, D.S.; MACKAY, T.F.C. Introduction to quantitative genetics. 4.ed. New York: Longman, 1996. 464p.

FEHR, W.R. Principles of cultivar development. New York: Macmillan Publishing Company, 1987. 536p. 
GERALDI, I.O. Estimação de parâmetros genéticos de caracteres do pendão em milho (Zea mays L.) e perspectivas de melhoramento. Piracicaba, 1977. 103p. Dissertação (M.S.) Escola Superior de Agricultura "Luiz de Queiroz", Universidade de São Paulo.

GIECO, J.O. Interação genótipos x ambientes e implicações para o melhoramento da soja. Piracicaba, 1997. 98p. Dissertação (M.S.) - Escola Superior de Agricultura "Luiz de Queiroz", Universidade de São Paulo.

GRAHAM, M.J.; NICKELL, C.D.; HOEFT, R.G. Inheritance of manganese deficiency in soybean. Crop Science, v.35, n.4, p.1007-1010, 1995.

HANSON, W.D. Heritability. In: HANSON, W.D.; ROBINSON, H.F. Statistical genetics and plant breeding. Washington: NAS-NCR, 1963. p.125-139.

HUANG, J.C.; TONG, C.L. Analyses on the variation of protein and fat and their correlation in will soybean in Fujian. Fujian Agricultural Science and Technology, v.1, n.7-8, 1990. /Resumo 1096 em Plant Breeding Abstracts, v.61, n.1, p.137, 1991/

JACQUARD, A. Heritability: one word, three concepts. Biometrics, v.39, n.2, p.465-477, 1983.

JANNINK, J.L.; ORF, J.H.; JORDAN, N.R.; SHAW, R.G. Index selection for weed suppressive ability in soybean. Crop Science, v.40, n.4, p.1087-1094, 2000.

JOHNSON, H.W.; ROBINSON, H.F.; COMSTOCK, R.E. Genotypic and phenotypic correlations in soybeans and their implications in selection. Agronomy Journal, v.47, n.10, p.477-483, 1955.

KEMPTHORNE, O. An introduction to genetic statistics. New York: John Wiley \& Sons, 1966. 545p.

KILGORE-NORQUEST, L.; SNELLER, C.H. Effect of stem termination on soybean traits in southern U.S. production systems. Crop Science, v.40, n.1, p.83-90, 2000.

KIM, H.S.; DIERS, B.W. Inheritance of partial resistance to sclerotinia stem rot in soybean. Crop Science, v.40, n.1, p.55-61, 2000. 
KNAPP, S.J.; STROUP, W.W.; ROSS, W.M. Exact confidence intervals for heritability on a progeny mean basis. Crop Science, v.25, n.1, p.192-194, 1985.

LAÍNEZ-MEJÍA, J.R. Implicações da interação genótipos $x$ ambientes na seleção de progênies de soja com ênfase nas produtividades de grãos e óleo. Piracicaba, 1996. 145p. Tese (D.S.) - Escola Superior de Agricultura "Luiz de Queiroz", Universidade de São Paulo.

LI, X.; WANG, J.; YANG, Q. JIAO, S.; WANG, L. The effect of selection method on the association of yield and seed protein with agronomic characters in an interspecific cross of soybean. http://www.soygenetics.org/articles/sgn1999-002.html (18 Ago 2001).

LIU, K.; ORTHOEFER, F.; BROWN, E.A. Association of seed size with genitypic variation in the chemical constituents of soybeans. Journal of the American Oil Chemists Society, v.72, n.2, p.189-192, 1995.

MARSCHALEK, R. Correlações genéticas e fenotípicas entre produção de grãos, teor de proteína e teor de óleo em soja, em vários ambientes. Piracicaba, 1995. 103p. Dissertação (M.S.) - Escola Superior de Agricultura "Luiz de Queiroz", Universidade de São Paulo.

MAURO, A.O.; SEDIYAMA, T.; SEDIYAMA, C.S. Estimativas de parâmetros genéticos em diferentes tipos de parcelas experimentais em soja. Pesquisa Agropecuária Brasileira, v.30, n.5, p.667-672, 1995.

MAURO, A.O.; OLIVEIRA, R.C.; MARCONDES, A.F.; SEDIYAMA, T. Ganho genético por seleção em linhagens de soja. Revista Ceres, v.47, n.270, p.135-144, 2000.

OLIVEIRA, A.C.B. de; SEDIYAMA, C.S.; CRUZ, C.D. Selection for later flowering in soybean (Glycine max L. Merrill) $F_{2}$ populations cultivated under short day conditions. Genetics and Molecular Biology, v.22, n.1, p.243-247, 1999.

PANTALONE, V.R.; BURTON, J.W.; CARTER JUNIOR, T.E. Soybean fibrous root heritability and genotypic correlations with agronomic and seed quality traits. Crop Science, v.36, n.5, p.1120-1125, 1996.

PAZDERNIK, D.L.; GRAHAM, P.H.; ORF, J.H. Variation in the pattern of nitrogen accumulation and distribution in soybean. Crop Science, v.37, n.5, p.1482-1487, 1997. 
PESEK, J.; BAKER, R.J. Comparison of predict and observed responses to selection for yield in wheat. Canadian Journal of Plant Sciences, v.51, n.3, p.187-192, 1971.

PIMENTEL, A.M. Cruzamentos dialélicos em soja com ênfase em teor de proteína e produção de grãos. Piracicaba, 1991. 150p. Dissertação (M.S.) - Escola Superior de Agricultura "Luiz de Queiroz", Universidade de São Paulo.

PRADO, L.C. Perspectivas para o melhoramento de linhagens homozigóticas de soja, com ênfase em produção de grãos e teor de proteína. Piracicaba, 1994. 128p. Dissertação (M.S.) - Escola Superior de Agricultura “Luiz de Queiroz”, Universidade de São Paulo.

PRADO, L.C. Estratégias de seleção em soja com base na avaliação em vários anos. Piracicaba, 1999. 112p. Tese (D.S.) - Escola Superior de Agricultura "Luiz de Queiroz", Universidade de São Paulo.

PULCINELLI, C.E. Avaliação de cruzamentos dialélicos de soja em gerações avançadas de endogamia. Piracicaba, 1997. 165p. Tese (D.S.) - Escola Superior de Agricultura "Luiz de Queiroz", Universidade de São Paulo.

QI, Y.; WANG, J. Agronomic traits correlative analysis between interspecific and intraspecific soybean crosses. http://www.soygenetics.org/articles/sgn2000-003.htm (18 Ago 2001).

QIU, B.X.; RAO ARELLI, A.P.; SLEPER, D.A. RFLP markers associated with soybean oil and protein concentration. Soybean Genetics Newsletter, v.24, p.206-207, 1997.

RAMALHO, M.A.P.; SANTOS, J.B.; ZIMMERMANN, M.J.O. Genética quantitativa em plantas autógamas: aplicações ao melhoramento do feijoeiro. Goiânia: Editora da UFG, 1993. $271 \mathrm{p}$.

RAMALHO, M.; SANTOS, J.B.; PINTO, C.B. Genética na agropecuária. 7.ed. São Paulo: Editora Globo, 2000. 359p.

RANZANI, G.; FREIRE, O.; KINJO, T. Carta de solos do municípios de Piracicaba. Piracicaba: Escola Superior de Agricultura "Luiz de Queiroz", Centro de Estudos de Solos, 1966. 85p. 
REBETZKE, G.J.; BURTON, J.W.; CARTER JUNIOR, T.E.; WILSON, R.F. Changes in agronomic and seed characteristics with selection for reduced palmitic acid content in soybean. Crop Science, v.38, n.2, p.297-303, 1998.

REIS, E.F. Ganhos preditos e realizados, por diferentes estratégias de seleção, em populações de soja (Glycine max (L.) Merrill). Viçosa, 2000. 120p. Tese (D.S.) - Universidade Federal de Viçosa.

ROBINSON, P. Heritability: a second look. In: HANSON, W.D.; ROBINSON, H.F. Statistical genetics and plant breeding. Washington: NAS-NCR, 1963. p.609-614.

SANTOS, C.A.F.; REIS, M.S.; SEDIYAMA, C.S.; CRUZ, C.D.; SEDIYAMA, T. Parâmetros genéticos e seleção indireta de progênies $\mathrm{F}_{6}$ de um cruzamento de soja (Glycine max (L.) Merrill). Revista Ceres, v.42, n.240, p.155-166, 1995.

SAS Institute Inc. SAS OnlineDoc®, Version 8. http://www.sas.com/ (31 Oct 2001).

SEBERN, N.A.; LAMBERT, J.W. Effect of stratification for percent protein in two soybean populations. Crop Science, v.24, n.2, p.225-228, 1984.

SIMPSON, A.M.; WILCOX, J.R. Genetic and phenotypic associations of agronomic characteristics in four high protein soybean populations. Crop Science, v.23, n.6, p.1077$1081,1983$.

SNEDECOR, G.W.; COCHRAN, W.G. Statistical Methods. 7.ed. Ames: The lowa University Press, 1980. 507p.

SNELLER, C.H.; DOMBEK, D. Use of irrigation in selection for soybean yield potential under drought. Crop Science, v.37, n.4, p.1141-1147, 1997.

SPEHAR, C.R. Diallel analysis for grain yield and mineral absorption rate of soybeans grown in acid Brazilian Savannah soil. Pesquisa Agropecuária Brasileira, v.34, n.6, p.1003-1009, 1999. 
SRIVASTAVA, A.N.; JAIN, J.K. Variability and coheritability estimates for physiological and economic attributes in soybean. Indian Journal of Genetics and Plant Breeding, v.54, n.2, p.179-183, 1994.

STEEL, R.G.D.; TORRIE, J.H. Principles and procedures of statistics. 2.ed. New York: McGraw-Hill Book Company, 1980. 633p.

TAWARE, S.P.; RAUT, V.M.; HALVANKAR, G.B.; PATIL, V.P. Phenotypic variability and character association in some vegetable soybean varieties. Journal of Maharashtra Agricultural Universities, v.20, n.3, p.454, 1995.

TAWARE, S.P.; HALVANKAR, G.B.; RAUT, V.M. Variability, correlation and path analysis in some germplasm lines of soybean (Glycine max) with high oil content. Indian Journal of Agricultural Sciences, v.67, n.10, p.476-477, 1997.

TRILLER, C.; TOLEDO, J.F.F. de. Using the $F_{3}$ generation for predicting the breeding potential of soybean crosses. Brazilian Journal of Genetics, v.19, n.2, p.289-294, 1996.

TOLEDO, J.F.F. de; ARIAS, C.A.A.; OLIVEIRA, M.F. de; TRILLER, C.; MIRANDA, Z. de F.S. Genetical and environmental analyses of yield in six biparental soybean crosses. Pesquisa Agropecuária Brasileira, v.35, n.9, p.1783-1796, 2000.

TYLER, J.M. Note on variation in germinability among early-maturing soybean populations. Field Crops Research, v.62, n.2-3, p.177-180, 1999.

UNÊDA-TREVISOLI, S.H. Estabilidade fenotípica e potencialidade de progênies obtidas por cruzamentos óctuplos em soja. Piracicaba, 1999. 228p. Tese (D.S.) - Escola Superior de Agricultura "Luiz de Queiroz", Universidade de São Paulo.

VENCOVSKY, R. Alguns aspectos teóricos e aplicados a cruzamentos dialélicos de variedades. Piracicaba, 1970. 112p. Tese (Livre Docente) - Escola Superior de Agricultura "Luiz de Queiroz", Universidade de São Paulo.

VENCOVSKY, R. Herança quantitativa. In: PATERNIANI, E.; VIEGAS, G.P. (ed.) Melhoramento e produção e milho. Campinas: Fundação Cargill, 1987, v.1, p.137-214. 
VENCOVSKY, R.; BARRIGA, P. Genética biométrica no fitomelhoramento. Ribeirão Preto: Sociedade Brasileira de Genética, 1992. 486p.

VOLLMANN, J.; FRITZ, C.N.; WAGENTRISTL, H.; RUCKENBAUER, P. Environmental and genetic variation of soybean seed protein content under Central European growing conditions. Journal of the Science of Food and Agriculture, v.80, n.9, p.1300-1306, 2000.

WEHRMANN, V.K.; FEHR, W.R.; CIANZIO, S.R.; CAVINS, J.F. Transfer of high seed protein to high-yielding soybean cultivars. Crop Science, v.25, n.5, p.927-931, 1987. 
APÊNDICE

Programas utilizados no SAS 


\section{Programas utilizados no SAS}

Programa utilizado para a obtenção das análises de variância individuais para cada ano e análises de variância conjuntas dos quatro anos de avaliação, para os caracteres altura da planta na maturação (AP), acamamento (AC), número de dias para maturação (DM) e produção de grãos (PG):

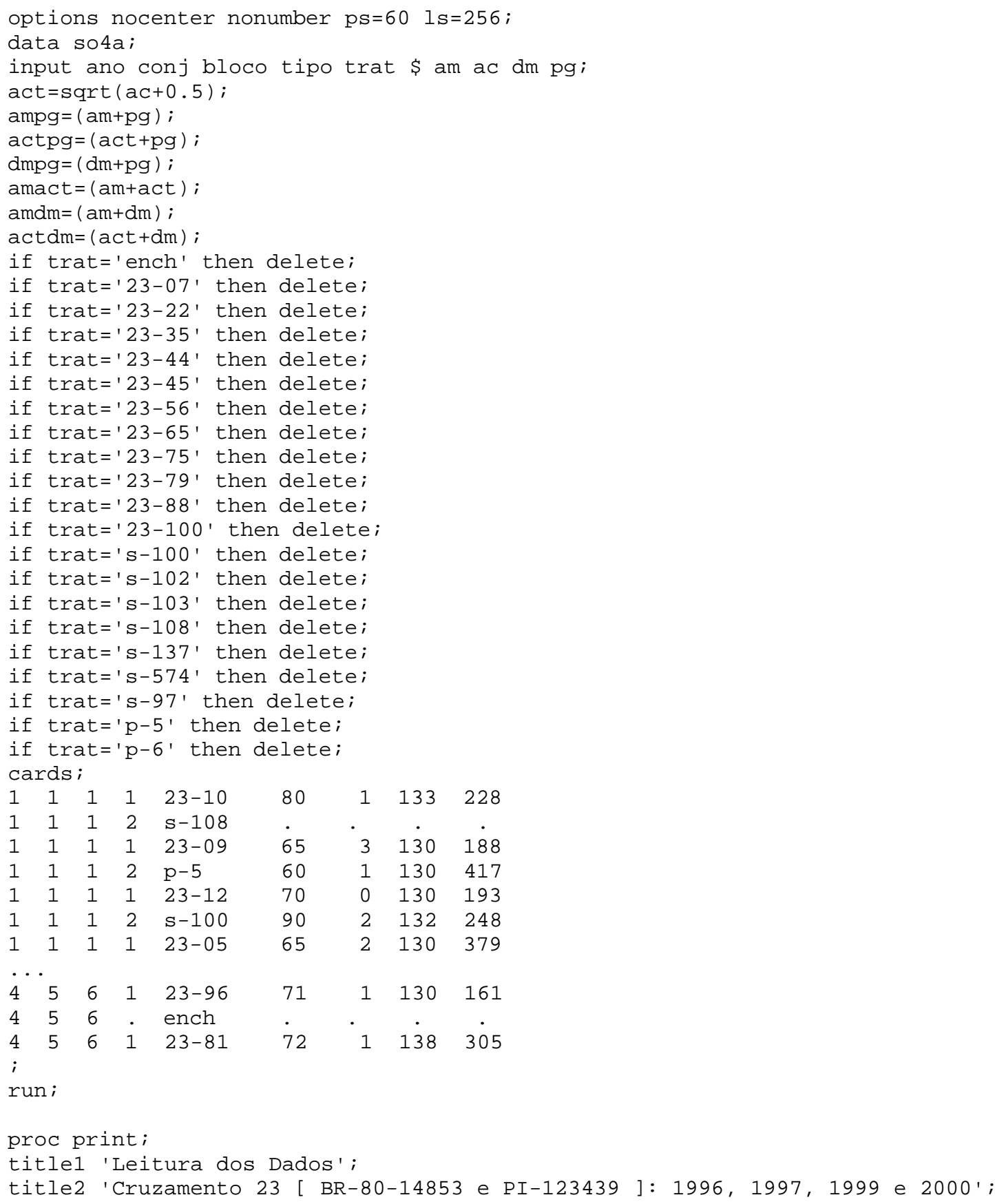




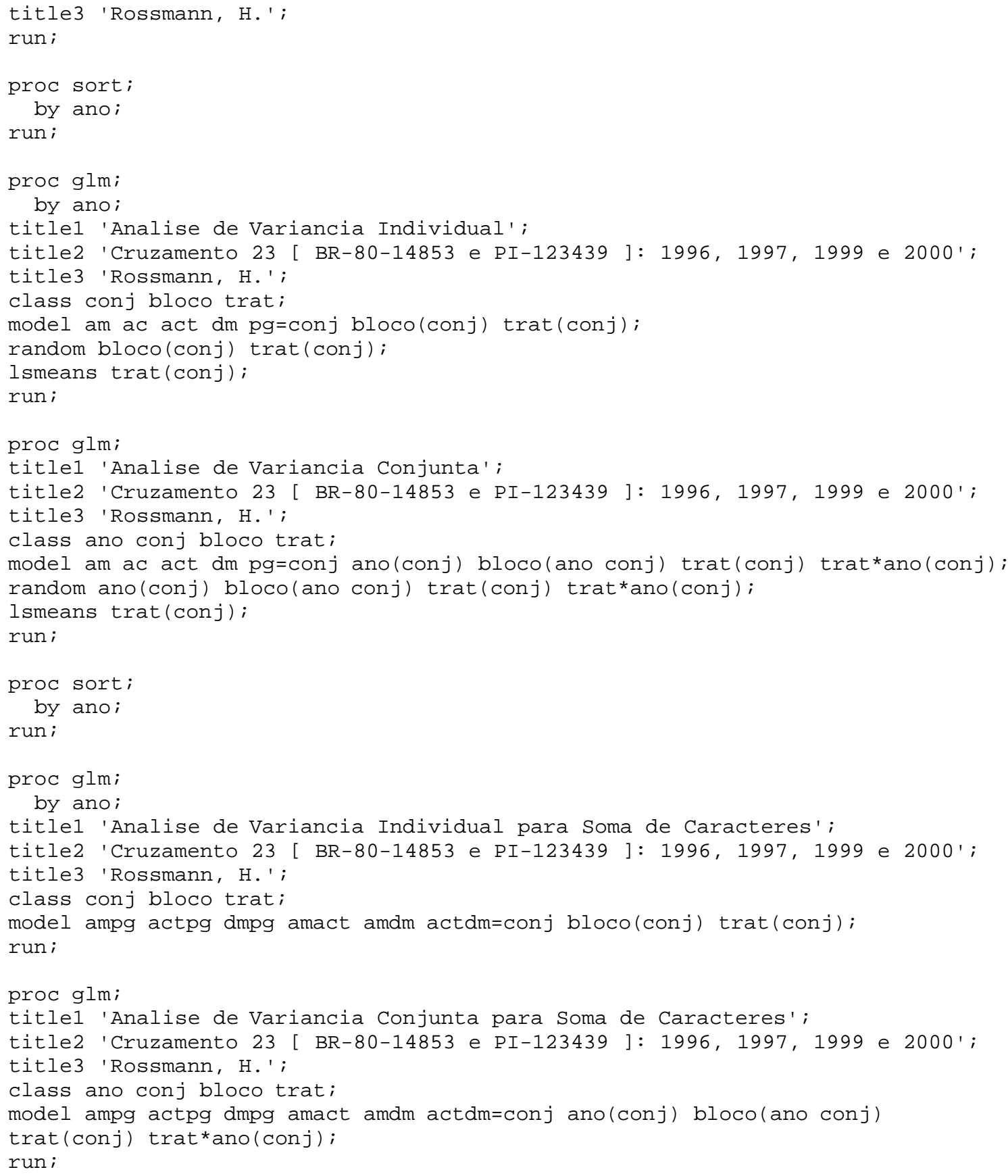


Programa utilizado para a obtenção dos valores tabelados de Qui-quadrado e $F$, para os respectivos graus de liberdade associados, utilizados na determinação dos intervalos de confiança associados às estimativas das variâncias do erro experimental, das variâncias genéticas entre linhagens e dos coeficientes de herdabilidade nas análises individuais para cada ano:

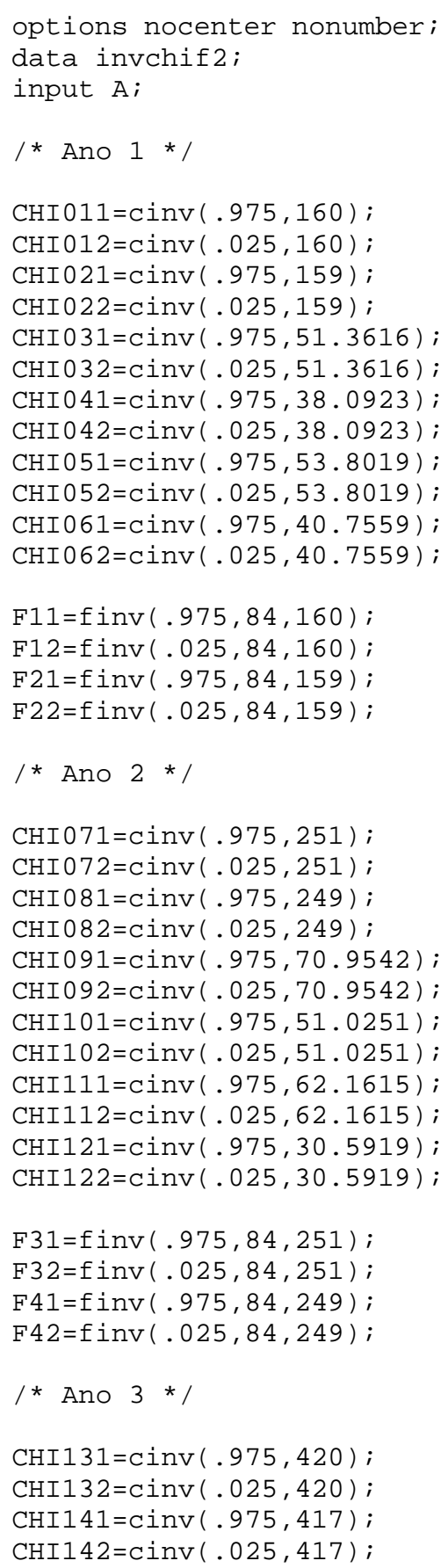




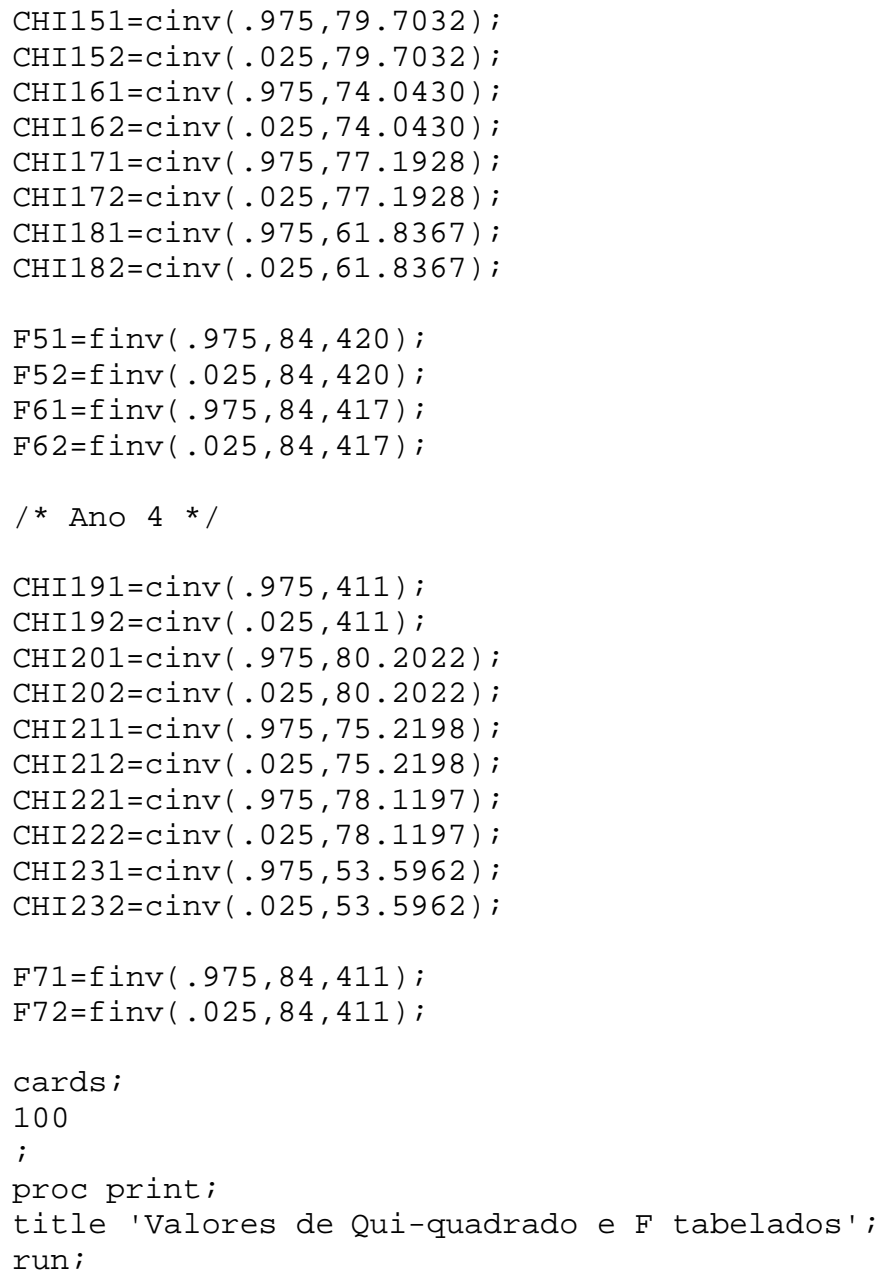


Programa utilizado para a obtenção dos valores tabelados de Qui-quadrado e $F$, para os respectivos graus de liberdade associados, utilizados na determinação dos intervalos de confiança associados às estimativas das variâncias do erro experimental, das variâncias genéticas entre linhagens, das variâncias da interação de linhagens com anos e dos coeficientes de herdabilidade nas análises conjuntas:

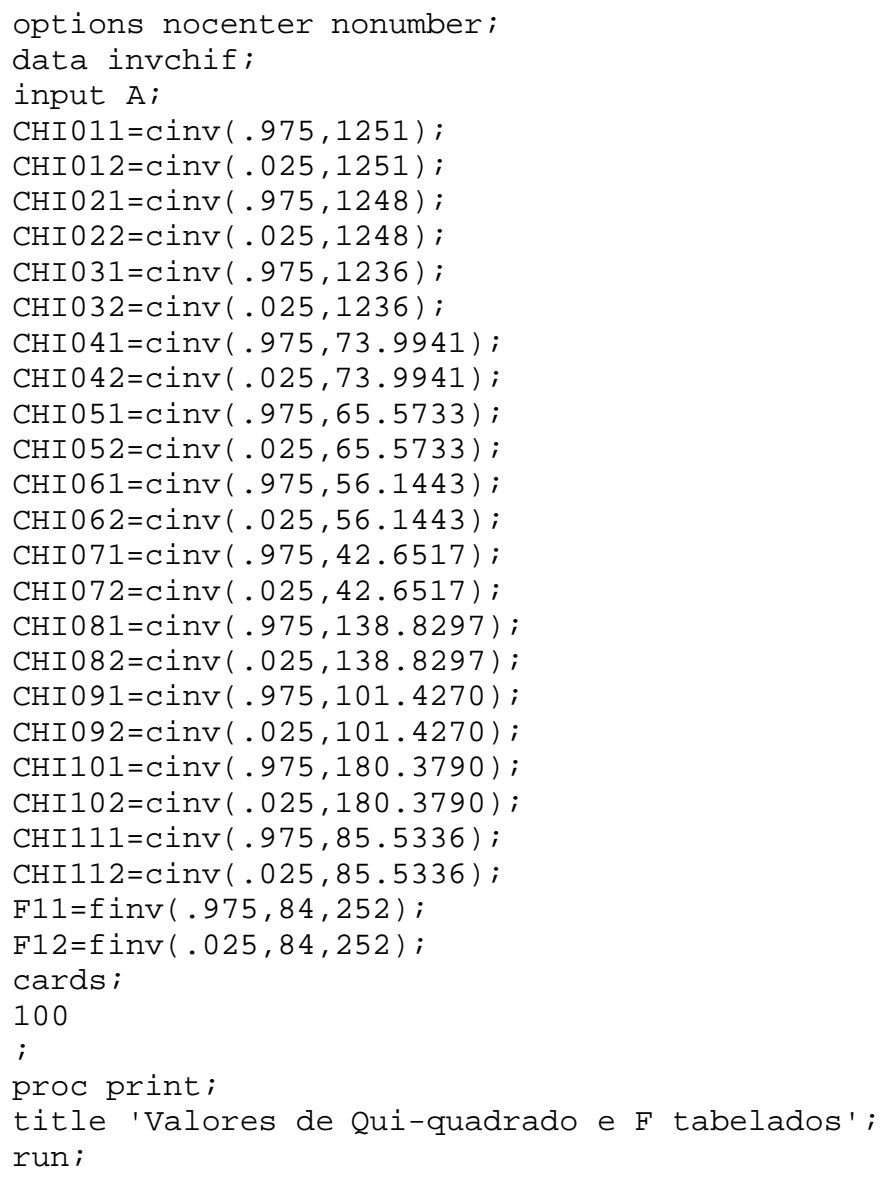

